\title{
NUFOORSCHE FABELEN EN VERTELLINGEN
}

\author{
MEDEGEDEELD EN VERTAALD DOOR \\ F. J. F. VAN HASSELT \\ Zendeling der Utrechtsche Zending Vereeniging.
}

Enkele jaren geleden, vroeg Dr. Adriani van Posso mij, of er van de Papoea's uit mijne omgeving dierenverhalen en andere bekend waren. Ik antwoordde ontkennend. Een volgende brief van Dr. A. zei me : "Ze moeten er zijn, blijf maar zoeken." Maar men begreep mij niet, of men wilde me niet begrijpen, in elk geval, ik vernam er niet één, tot ik eens in mijn school voor de hoogste leerlingen dikteerde de fabel van La Fontaine over "De duif en de mier." Den volgenden dag luisterde ik een gesprek van twee schoolmeisjes af: "Gisteren hadt je op school moeten zijn, toen heeft mijnheer een kakōfein verteld." "Je meent zeker sarber?" was het antwoord. Dat waren twee woorden, die ik niet kende. Bij navraag hoorde $i k$, dat het verhaal van duif en mier een kakōfein was en dat raadsels, waaronder ze ook uit het hoofd rekenen telden, "sarber" was. $\mathrm{Nu}$ was $\mathrm{ik}$ een heel eind verder. Maar toch weigerde men mij nog kakōfein te vertellen, tot ik 't eens vroeg op 'n avond. En toen kwamen ze los. Later vernam ik, dat men vóór zonsondergang geen fabelen vertelde, want als men dat deed, vloog de negorij in brand. 's Avonds was men immer gewillig mij op dit gebied te woord te staan. De tabak, die de verhaler als zijn honorarium bekwam, werkte daartoe mede.

Ik beproefde dikwijls de verhalen ook door anderen dan den oorspronkelijken verteller, me te laten meedeelen. Meermalen echter vernam ik dan, dat dit of dat verhaal het bijzonder eigendom was van deze of gene en ik me om inlichting tot hem of haar moest wenden. Soms gebeurde het ook wel, dat iemand, die het monopolie voor een of ander verhaal meende te bezitten, er niets over gesticht was, te vernemen, dat een ander hem 't gras al voor de voeten had weggemaid.

Er bleef mij bij mijne andere werkzaamheden niet veel tijd over voor dit werk. De verzameling is dan ook niet volledig. Van sommige 
verhalen heb ik aanteekeningen gemaakt. Daar ik de verhalen zelve echter niet had, liet ik de mededeeling er van achterwege.

Mij zelven brachten deze werkzaamheden de kennis van verscheidene woorden aan, en de wijze te weten, waarop een Papoea verhaalt, was mij ook van nut, wanneer ik hun vertelde, wat ik te zeggen had. Kort nadat ik begonnen was mijne eerste Nufoorsche fabelen op papier te zetten, zond mijn collega Van der Roest, toen wd. Zendeling op Windessie, mij een afdruk van hetgeen hij in het Tijdschr. voor Ind. Taal-, Land- en Volkenk. Deel XL had medegedeeld uit het leven der bevolking van Windessi (N.G.) Hier vond ik vier verhalen van de soort, die ik ook van de Nufooren beproefde te vernemen.

$\mathrm{Zij}$, die Indonesische vertellingen kennen, vinden in de volgende blz. meer dan één oude bekende weder.

Ik ga me niet wagen aan vergelijking dezer Nufoorsche vertellingen met de verhalen van elders bekend. Bevoegdere hand wil dit wellicht van mij overnemen.

Een enkele maal verwijs ik naar de Spraakkunst der Nuf. Taal. Ik bedoel dan mijne Spraakk., onlangs uitgegeven door het Kon. Inst. voor de Taal-, Land- en Volkenkunde van Nederl.-Indië.

Ik volgde in de volgende blz. de spelling, die ik in bedoelde Spraakk. mij tot regel stelde, n.l.

a. klinkende als in het Holl. lam, Sam enz., b.v. in sam (warm) kam (alle) enz. wordt geschreven ā.

a. naderende de Holl. aa, als in kamari (vader), s'aser (zij volgen) enz. wordt geschreven a.

e. klinkende als in het Holl. nek, bek, enz., in nek (geit), mek (koffertje van bladeren), wordt geschreven ē.

e. naderende de Holl. ee, in wendi, jedi, wordt geschreven e.

e. als in het Holl. voorv. be, als de tweede e van regen, b.v. in manggĕnēm, bejĕn, wordt geschreven ě:

i. als in het Holl. missen, b.v. in sisĕn (sluiten), wordt geschreven ì.

i. als in het Holl. mier, riem, b.v. in rim (vijf), nin (schaduw) wordt geschreven $\mathrm{i}$.

i. in uitspraak het midden houdende tusschen e en $\mathrm{i}$ b. v. in mesĕr, dat soms ook misĕr klinkt, wordt geschreven è.

o. als in het Holl. bok, ton, in rok (geluid), bon (berg), wordt geschreven $\overline{0}$.

o. naderende de Holl. oo, b. v. in for (vangen), kor (tellen), wordt geschreven 0 .

u. klinkt als de Holl. oe.

v. H. 


\section{NUFOORSCHE FABELEN EN ANDERE VERTELLINGEN.}

1. Māmbinō, diōn( (') ma wōngor.

Dion, i mām aibōn nā bor ro meōs ōso-i d'or māmbinō : "Naik, $\left({ }^{2}\right)$ w'un aja be meos, ta j’akan aibōn". Mambinō i pōk dion, ma i d'un i be meōs. Ānsōna māmbino, i mārisein, i bur wer, bape dion, i meōf ba; i pas māmbinō kum. Bape kum na sur wer, māmbinō i bur wer. Dion i d'or: "W'un aja wer!" Bape māmbinō d'ōbo $\left({ }^{3}\right)$ : "Wa srer aja bĕpōn kwar, ānsōna jun au ba. Dion i d'āwaw ${ }^{4}$ ro meōs.

Rās ōso, i mām wōngor, i d'èněf ro kajĕn. I frur weür $\left({ }^{5}\right)$ nā bor ro kajĕn, rēsěri i d'or wōngor, ma i kōfein : "Wa mārisein, nēri k'ĕmbrōb, $\left({ }^{6}\right)$ wa mām kāwāsa jedi, si bor kāku.

Ma wōngor, i mām weür na bor ro kajen, i kofein : "Kaku, kāwassa bedi, si bor kaku. Su fes rōb $\left({ }^{7}\right)$ fa s'èmbrōb. Wōngor, si bor, s'rāma fa s'ěmbrōb diōnsi.

Diōn i kōfein : "Ja kor mgo rēsĕri, bāpe mgo rir mgo be sup běba". Ma wōngor, si rir si. Diōn i d'ōpĕr ro bo wōngor si krusna, i kor : "Ōser, suru, kiör, isōf wōngor bepur. I prer i, ma i d'ōpĕr be sup bĕba.

\section{. 1. Reiger, aap en krokodil.}

Een aap, die vele vruchten op 'n eiland ziet, roept tot een reiger: "Broeder, breng mij naar 't eiland, opdat ik meê vruchten eet". De reiger draagt den aap, en brengt hem naar 't eiland: Nu wenscht de reiger weer te vertrekken, maar de aap wil niet; hij trekt hem de vederen uit. Maar als de veeren weer gegroeid zijn, vertrekt de reiger weer. De aap roept: "Neem mij weer mee." Maar de reiger zegt: "Gij hebt mij eerst belogen, nu neem ik je niet mee." De aap zit nu gevangen op 't eiland.

Op 'n dag ziet hij een krokodil slapen op het zand. Hij maakt vele voetstappen in het zand, en toen roept hij de krokodil en hij zegt: "zoo ge wilt, zullen we oorlog voeren; zie mijn volk, zij zijn groot in aantal".

En de krokodil, die vele voetstappen in het zand ziet, zegt: "Werkelijk, uw volk, is groot in antal." Zij kwamen overeen na hoevelen nachten ze samen oorlogen zouden. Vele krokodillen, komen om de apen te beoorlogen. 
De aap zegt: "Ik tel ulieden eerst, maar gij moet u eerst op eene rij leggen in de richting van het vaste land." En de krokodillen leggen zich op een rij. De aap springt op de ruggen der krokodillen, hij telt: "Eén, tweé, drie", tot de laatste krokodil. Hij slaat hem, en springt op 't vaste land.

1. Dion, a ap. Vauwaar die naam voor aap gekomen is, is niet zeker. Men vertelt, dat een schoenerkapitein John voor jaren een aap meebracht en een verbastering van den naam Johu zou de oorzaak zijn. Naar een der oudere Nufooren me vertelde, zou vroeger de naam "rut" gangbaar zijn geweest. Het eiland Batjan, 't eerste eiland vau af N. Guinea, waar apen in grooten getale zich ophouden, zou daarnaar Meos Ruti, apeneiland, heeten.

2. Naik, broeder, in 't algemeen een familielid van dezelfde kunne als spreker of spreekster.

3. $\overline{\mathrm{O}} \mathrm{b} \overline{\mathrm{o}}$. Hier gebruikt in den zin van zeggen. 't Wordt doorgaans vragend" gebezigd: "Wat zegt hij" of hij herzegt. Ook als zeggen gebruikt men het, wanneer men iemands woorden aanhaalt.

4. Awaw. Hier door mij vertaald als gevangen zitten. In 't algemeen voor: in den val loopen, in de klem zitten, in nood zijn.

5. We ür. Samengesteld uit we (voet) en ur. Ur komt in samenstellingen voor als achter, na. Hier dus, wat de voet achterlaat, voetstap.

6. Ëmbrōb. Oorlog voeren. Ook als z.n.w. oorlog.

7. Fes rōb. Lett. "nachten binden". Wanneer Papua's een afspraak maken omtrent eenigen tijd, dan nemen de partijen ieder een touw en leggen daarin zoovele knoopen, als het aantal nachten is, dat hen van een weder ontmoeten scheidt.

\section{Diōn kukĕr māngōmbräb.}

Diōn i kōfein faro māngōmbrāb: "Nāpirmo, nu ker diaf". Māngōmbrāb i kofein: "Bje". Ma dion i ker diaf ro der, (') māngōmbrāb ro sup kāku.

Ro isna diāf diōn bjeda i ro kwar, bape māngōmbrāb diāf bjeda i bje-Rōkaker i kaki, diōn i d'ek ro bjefknām, ma i d'an bjef kraf, ma pis i san faro māngōmbrāb. Māngōmbrāb i d'or: "Napirmo, wa buk maro aja kakō", bape diōn i kōfein : "K'an rosei, is ōrnĕ muuda". Wārpur wer māugōmbrāb i fukĕn faro diōn, i d'ek āmiun, ma diōn i d'ek āmiun, bāpe i san faro māngōmbrāb pis munda. Māngōmbrab i d'or wer: "Napirmo, wa buk amiun maro 
aja kako". Bape diōn i karĕm wer: "Je buk faro au, aja, j'an rosei ?"

Māngōmbrāb, i msor, i bur, i d'ōf fanām nakaknāın, ma i knom be nakabōn. Diōn i serf mangōmbrāb, d’ōbo: "Napirmō, wa kein ro mōbo ?" Diōn i mām māngōmbrāb, i knom nakabōn, i d'ek naka, ma i d'an bōn. Māngōmbrāb i d'or wer, bape diōn i karĕm rariria munda.

Māngōmbrāb i mbrein ānsōna be mārisān i běbơn nabor kaku. Dion i serf i, i mām māngōmbrāb i knom be mārisān, i fukĕn : "K'an bōn ōrně ?" Māngōmbrāb i karĕm : "K’an baboi !" Dion i pānuk mārisān, rwasi i fo, i d'an na, i käpusasěr i, i d'ar naba : "Rās ini ja mar, rās ini ja mar!"

Warpur wer diōn i mām māngōmbrāb, i d'ōf ro knām afuri. Diōn i mam mniwĕrnas ro knām, i fukĕn faro māngōmbrāb: "Rosei is ōrnĕ ?" Māngōmbrāb i kōfein : "Mānsĕrēn mawōn bjeda." Diōn i kōfein : "Nēri ja kuk mawōn?" Māngömbrāb d’ōbo : "Wa kuk i baboi !" ma i d'ōf fāsau. Diōn i prer mniwērnas, ma mniwer, si kaimnepĕn i diōn i d'arōu ro war.

Māngōmbrāb i d'ôf ro āsri dōri. Diōn i serf i, d'or i: "Napirmo, wa kein ro ?" "Aja ìs ōrnĕ !" māngōmbrāb i karĕm. Diōn i kein ro bo āsri, māngōmbrāb ro wabni. Dion i swarepěn, kāparsi si karĕm, i snēri sām, i kin ādāf, ma i prer kaparsi, i mar.

\section{De aap en de landschildpad.}

Een aap zegt tot een landschildpad: "Neef, laten we een tuin planten“. De laudschildpad zegt: "Goed." En de aap plant een tuin op de der ${ }^{1}$, de landschildpad op het echte land.

Toen het licht werd, was de tuin van den aap vernietigd, maar de tuin van de landschildpad was goed. Toen het plantsoen hoog was, klom de aap in een pisangboom, en hij at het vleesch van de pisang, en de schil wierp hij de landschildpad toe. De landschildpad riep: "Neef, geef aan mij ook wat!" maar de aap zeide: "Wat praat ge van eteu, dat is alles!" Later weer vroeg de landschildpad den aap in een djamboeboom te klimmen, en de aap klom in den djamboeboom, maar hij wierp de landschildpad de schillen slechts toe. De landschildpad riep weer: "Neef, geef an mij ook een djamboe!„ Maar de aap antwoordde weer: "Wat eet ik anders dan hetgeen ik u geef“. De landschilpad werd boos, en ging heen. Zij verborg zich bij een nangkaboom, en ze keek naar de nangkavrucht. De aap zocht de landschildpad en hij zeide: "Neef, waar 
zit ge?/ De aap ziende, dat de landschildpad naar de nangkavrucht kijkt, klimt in de nangka, en hij eet de vrucht. De landschildpad vraagt weer, maar de aap antwoordt slechts met dezelfde woorden.

De landschildpad gaat nu naar een Spaanschepeperstruik, die vele vruchten droeg. De aap zoekt haar; hij ziet de landschildpad turen naar de Spaansche peper, en hij vraagt: "Knnnen we die vrucht eten?" De landschildpad antwoordt: "Zeker, kunnen we die eten!" De- aap plukt Spaansche peper, een hand vol, hij eet die en bepoept zich en hij schreeuwt hard: "Heden ga ik dood, heden ga ik dood!"

Later weer ziet de aap de schildpad, die zich verstopt onder een boom. De aap een wespennest aan den boom ziende, vraagt aan de landschildpad: "Wat is dit?" De landschildpad zegt: "De gong van den heer" (den gebieder) De aap zegt: "Zal ik op de gong slaan?" De landschildpad: "Waarom zoudt ge er niet op slaan?" En ze verstopt zich spoedig. De aap slaat op het wespeunest, waarop de wespen hem bedekken; en de aap duikt in het water.

De landschildpad verstopt zich in een rijstblok. De aap zoekt haar, hij roept haar: "Waar zit ge?" "Ik ben hier", antwoordt de landschildpad. De aap zit boven op het rijstblok, de landschildpad er onder. De aap denkt, dat zijne testes antwoorden, hij wordt boos, hij neemt een rijststamper en hij slaat zijne testes, eu hij sterft.

1. Der. Dit woord beteekent ebbe. Maar 't wordt ook gebruikt voor het gedeelte der kust, dat bij eb droog is en bij vloed, overstroomd wordt.

2. Baboi. Is te vertalen door welzeker, zeker, waarom uiet.

\section{Wōnge, māmbruk ma karau. (1)}

Wōnge, māmbruk ma kārau, si borěs. Wōnge i fara, māmbruk i kein ro wāraundi, karau i kein ro fandu, i nārĕın war.

Wōnge, i fara, i mam mămbruk sāmōn bjeda, i mārārer, i swārepĕn sāmōm i mārārer snaro māmbruk i kein ro wai rauudi, i d'or: "Napiro, au, wa fara, ja kein ro mob beda. Irirya māmbruk i fara, bape ānsōma wōnge, i mōm sāmōn ani i mārārer wer -i mārisein māmbruk ma i, su fāmfārōwe wer.

Su fāmfārōwe raririsa běkior, bĕfiāk, wōnge, i d'arĕf wer ro wai, wa i mef, war i d'ek ro wa. Ānsōna māmbruk, wōnge, su kin karau, su pampum karau sābir $\left(^{2}\right)$ ro pāngir, karau mgasi i kein fiōro ro pangir, mgasi bjeda i kapirare isof ānsōna. 
Wōnge, māmbruk, su mām wau, i piar ro māsĕn, s’or i : "Nāpirō, wa kobeda i mef, knîko ko msar, ko kon ro krumbri kāda, w'un ko be sup". Wau i rama; wōnge, māmbruk ma karau, si kein ro kruri bjeda, ma wau i d'as be sup. Der $\left({ }^{2}\right)$ isof wepursi, wau i kofein: "ānsōna mgo sabu, ja mkah der". Bape wōnge, si kōfein : "Ko biäsa māsěnba, w'un ko be sup kaker". Der isof wekurbsi, wōnge si sabu, bape māmbruk i kin wau ro rowar ōso, wōnge ro rowar wēsĕ, ma kārau, i pāmpum i ro krōri-iririja si sjob i be sup. Si sma ānsōna sisipu $\left({ }^{3}\right)$ ma rōbebre. $\left({ }^{4}\right)$ Si pāmbar wau ma si kōfein fāro sisipu, rōbĕbre, su djaga $\left({ }^{5}\right)$ wau, i bur awer.

Wōnge, si serf āmiais fa si kun wau. Ro sup, $\left({ }^{6}\right)$ si sma wāndo; s'or i kakō fa i d'akserf āmiais ma i d'akan wau.

Si sìbĕr wer, si frur rōkēf $\left({ }^{7}\right)$. Bapa si seerf wau, si mam-i sjaba. Si serf sisipu, rōběbre su, -si mam su ba. Rōbĕbre i d'ōf ro aiknām âfuri. Wōnge i msor, i d'ārfepĕn i. I marba, bape isof ānsōua rōběbre i kākiba, i sjārbām. Sisipu i kein ro snau ro bo; wōnge, si kofein faro i: "Ānsōna wa baba kwar, $\left({ }^{8}\right)$ snaro wa djaga wau ba. Rjani ko mām, sisipu ānsōna i kāpirare. Bape wau mangundi i pambar wer, i bur be māsĕn.

3. Kasuaris, kroonduif en veldmuis.

De kasuaris, de kroonduif en de veldmuis roeiden. De kasuaris stuurde, de kroonduif zat vóór in de prauw, de veldmuis zat in 't midden, ze schepte water.

De kasuaris, die stuurt, ziet de kam van de kroonduif bewegen. Denkende, dat de kam beweegt, omdat de kroonduif voor in de prauw zit, roept hij: "Neef, stuur gij, dan zal ik op uwe plaats zitten." En nu stuurt de kroonduif, maar toch ziet de kasuaris die kam weer bewegen. Hij wil dat kroonduif en hij weer van plaats verwissclen.

Drie malen, vier malen hebben zij zóó omgewisseld, dan als de kasuaris weer in de prauw stapt, scheurt de prauw, en het water stijgt in de prauw. Nu grijpen kroonduif en kasuaris de veldmuis, en duwen de kop van de veldmuis in het gat. Het gezicht van de veldmuis zit lang in het gat, daarom is haar gezicht zóó klein, tot nu toe.

De kasuaris en kroonduif, een schildpad ziende drijven op zee, roepen haar toe: "Neef! onze prauw is gescheurd, zoo dadelijk zinken we, mogen we op uwe rug zitten? Breng ons naar land". De schildpad komt; de kasuaris en de kroonduif, zitten op haar rug en de schildpad zwemt naar land.

7• Volgr. VII. 
Als 't water tot de knieën komt, zegt de schildpad: "Nu moet ge afstijgen, ik ben bang voor de der. Maar de kasuaris met de anderen zeggen: "Wij zijn niet gewend aan zeewater, breng ons nog meer landwaarts". Als het water tot de enkels komt, dan stijgen de kasuaris en de andere af, maar de kroonduif grijpt de schildpad aan de é́ne zijde, de kasuaris aan de andere zij en de veldmuis duwt haar aan 't achterste; zóó trekken zij haar naar land. Zij vinden nu een sisipu en een kikvorsch. Zij keeres de schildpad om en zij bevelen de sisipu en de kikvorsch, op de schildpad te passen dat zij niet weggaat.

De kasuaris en de anderen zoeken brandhout, om de schildpad te roosteren. In het bosch vinden zij den jaarvogel; zij vragen hem ook brandhout te zoeken en mee de schildpad op te eten.

Als zij weer teruggekeerd zijn, maken zij een stellage. Maar als zij de schildpad zoeken, zien ze haar niet. Nu zoeken ze de sisipu en kikvorsch. Zij zien die twee niet. De kikvorsch heeft zich onder een boom verstopt. De kasuaris, die boos is, vertrapt haar. Ze was niet dood, maar tot heden is de kikvorsch niet hoog, ze is echter breed. De Sisipu zat op een tak boven in den boom; de kasuaris en de anderen zeggen tot haar: "Omdat ge niet gepast hebt op de schildpad, zult ge niet groot meer zijn." Alzoo zien wij, dat de sisipu nu klein is.

Maar de schildpad had zich zelve weer omgeworpen, en was naar zee gegaan.

1. Karau. Vertaald door veldmuis. Heeft de grootte van een rat; de karau is een geliefkoosd eten voor de $\mathrm{Faksi}$, de binnenlanders.

2. Der. Hier in de beteekenis van het water, dat bij vloed het land overstroomt, dat door de ebbe wordt drooggelaten.

3. Sisipu. Een vogel van de grootte eener spreeuw. Haar staart is voortdurend in beweging (gelijk bij de kwikstaarten). Volgens de legende zou de sisipu vroeger groot geweest zijn.

4. Rōbĕbre. Kikvorsch. De meer algemeene naam voor kikvorsch is krōkrō. Albrew ĕn, grondwoord bre, is het in de breedte groeien vau boomen. Rōbĕbre dus: ding, dat breed (plat) is.

5. D jaga. Dit Mal. woord heeft van oppassen in het Nuf. de beteekenis gekregen van beletten, tegenhouden.

6. Sup. is zoowel land als bosch.

7. Rōkĕf, stellage om visch, vleesch enz. te rooken of te roosteren.

8. K w a r is het hulp w.w. v. d. verl. tijd. In dezen zin, volgende op 
eenen ontk. vorm, laat het zeggen: 't is niet meer, wat het grondw. uitdrukt. Vroeger was de sisipu groot (ba), nu is het uit met hare grootheid.

\section{Nāf s'ob rumun, wōnge, wan.}

Rās ōso, rumun, nāt, wōnge ma wan, si disen ro Bintěfaria ( ${ }^{1}$ ) ro Arfu. Nāf mānsar i d'ak disĕn ma d'akmas maroba; i barēk ro pāfēn $\left({ }^{2}\right)$ munda.

Rumun, si sbar do se da kwar: "Sindo kōfnawa, $\left({ }^{3}\right)$ sindo kōfnawa!" Ānsōna nāf, si sbar do seda : "Ē kwari, sanjemo, ēkwari, sāujemo!"

Rumun ma wōnge, si mām nāf mānsar i d'akdisenba, si koriajĕr i be "mansar běbjeba, kāpārsi kwaim, i pokba rape." Nāf mānsar, ( ${ }^{4}$ ) i kōfeiu: "Rōmawa jesi, mgo mnāf ōrnĕ? Ma nāf kam, si msor. Nāf mānsar, i for bĕpōn rumun beba ma i d'ark i-i mar, ma romawa bjesi kam, ōso ōso i for rumun, wōnge, wan ōso, - rumun ōso i bur maroba. S'ark si kam, s'un si be swan, insa si kun si ro for. Nāf mānsar i jer, i pōkba i d'un rumun bĕba be swan. Knìko, i san rumun ma i mna, knìko i sau i wer, i mna. Rumun i mērbāk māngĕnēm, i swārepĕn — nēri i d'an běpejĕk rumun snēwarsi. I d'an i bro, i mbrain be swan, kāwāsā bjeda, si fukĕn: "W'un rumun bani ba?" Nāf mānsar i kōfein: "J'an bĕpejĕk i, i mafën wer mgo kun rumun awer.

Ānsōna naf kaim s'an rumun, wan, wōnge bĕpejěk munda. Bépōn kādā, si for si ma sun be snunsi, si kun si; nāf mānsar ani i fārkor si, s'an bĕpejĕk munda.

5. De honden blaffen tegen varkens, kasuarisen, $\mathrm{kang}$ aroes.

Op 'n dag hadden de varkens, de honden, de kasuarisen en kangaroes een zangpartij op de Bontefaria te Arfoe. Een oude hond zong en danste niet mede; hij lag maar in de asch.

De varkens hadden hun lied gezongen: "Sindo k of uawa, sindo kofnawa!" $\mathrm{Nu}$ zongen de honden hun lied: Ekwari, sānjemo, ēkwari, sānjemo!"

De varkens en de kasuarisen, ziende, dat de oude hond niet. meezong, scholden hem een "leelijke grijsaard, wiens scrotum lang was, die niet meer kon." De oude hond zeide: "Mijne jongens, hoort gij dit?/ En alle honden werden boos. De oude hond ving 't eerst het groote varken en beet hem, dat hij stierf, en al zijne 
jongens (volgelingen), één voor één vingen een varken, kasuaris of kangaroe, - niet één ontkwam. Zij beten hen allen, en brachten hen naar het strand, opdat zij ze op het vuur zouden roosteren. De oude hond alleen kon het groote varken niet naar het strand brengen. Als hij een eind geloopen heeft, werpt hij het varken neer en hij rust een weinig; dan werpt hij het weer neer, en rust weer. Het varken was te zwaar; daarom dacht hij: hij zal de varkensingewanden maar rauw eten. Hij eet het op, en dan loopt hij naar het strand. Zijn volk vraagt hem: "Brengt gij dat varken van u niet mee?" De oude hond zegt: "Ik heb hem rauw opgegeten, dat is lekkerder - roostert de varkens niet! „

$\mathrm{Nu}$ eten alle honden de varkens, kangaroes, kasuarisen maar rauw. Vroeger, toen vingen zij ze en brachten ze bij de menschen, die ze roosterden; die bewuste oude hond hij onderwees ze, dat zij ze maar rauw moesten eten.

1. Bontĕfaria. Een berg op Arfu, noordkust van N.G. Daar moet naar de verhalen der Papoea's een natuurlijke steenen wal zich bevinden, waarbinnen de bovenstaande fabel speelt. In dien wal is eene opening, waaruit twee kasuarisen toen zouden ontsnapt zijn, die vandaar hunnen weg namen naar de kust van Doreh, waar ze vriendschap sloten met de toen dár wonende voorouders der Noefooren.

2. Pāfĕn, asch, echter ook aschplaats, plaats, waar gekookt wordt, dus, waar 't warm is. Gewoonlijk de plaats, waar de ouderen van dagen zich koesteren.

3. Onvertaald gebleven, daar dit honden- en varkenslied, waarschijnlijk althans, geen Nufoorsch is.

4. Mansar. In het Nuf. oud, grijs. Oorspronkelijk schijnt de beteekenis geweest te zijn groot, a anzienlijk. Mantar is nog in het Nuf. groot van gestalte. In het Biaksch heeft mānsar de beteekenis van groote, aanzienlijke behouden. Het Nuf. mānsēr ěn (vrije, heer), schijnt ook met dit māntar (mānsar) samen te hangen. De oudsten uit de familie zijn ook gewoonlijk de hoofden, z. a. ook deze oude hond voorgesteld wordt als het hoofd der andere honden.

6. Ko sma manbĕsak ro sup kaim. (1)

Bĕpōn manbĕsak ma manaweri, $\left({ }^{2}\right)$ si kein ro Warōpĕn $\left({ }^{3}\right)$ munda. Ma wam barĕk i sja ma, si bur be Korare, $\left({ }^{4}\right)$ fa si sjom radja. $\left({ }^{5}\right)$ 
Rās ōso, manaweri, si fes wai seda kuker abra kaku, $\left({ }^{6}\right)$ bape si fnap abra kukĕr rudia, $\left({ }^{7}\right)$ rjani abra i rik. Manbĕsak, si fukĕn : "Mgo fes wai kukĕr rosei?" Manaweri, si karĕm : "Kukĕr roiram "• $\left({ }^{8}\right)$ Manběsak, si serf roiram, si kēruk na be kāpirare imnis abra, ma si fes wai seda. Si borěs knik-wam i pōk. $\left({ }^{9}\right)$ Manaweri wai seda, i pākrìk, s'awaw maroba, bape manbĕsak si fes wa seda kukĕr roiram-roiram i muk, ma wai i msar.

Manbĕsak, si rob ma si faspar-ōno, si bur be Ānsus, wēsĕ be Wāndāmĕn, wēsĕ be Sjēri, ma rariria ko sma manbĕsak ro sup kaim.

6. We vinden de paradijsvogel in alle landen.

Troeger vertoefden de paradijsvogel en de manaweri alleen op Warōpĕn. En met de west-moeson, gingen zij naar Tidore, om den radja schatting te brengen.

Op een dag bonden de manaweri hunne prauw op met echt touw, maar zij kookten het touw met rudia; daardoor wordt het touw rood. De Paradijsvogels vragen: "Waarmeê bindt ge uwe prauw op?" De manāweri antwoordden : "Met pandanusbladeren!" De paradijsvogels zochten nu pandanusbladeren, en sneden ze tot kleine stukken, gelijk touw, en bonden er hunne prauw meê. Als ze een eind geroeid hadden, werd de wind hevig. De prauw der manaweri was stevig, zij geraakten niet in nood, maar de paradijsvogels hadden hunne prauw met pandanusbladeren gebonden - de pandanusbladeren braken en de prauw zonk. De paradijsvogels vlogen op en verspreidden zich - enkele trokken naar Ansoes, andere naar Wandamen, andere naar Sjèri en dat is de oorzaak, waarom wij de paradijsvogel in alle landen vinden.

1. Sup kaim, alle landen. Bedoeld wordt de landstreken op en bij N. G.

2. Manaweri. Een trekvogel, die met de komst van den westmoeson N. G. verlaat en met den o. moeson terugkeert.

3. Wārōpĕn, kuststreek aan de z. zijde van de Wandamen baai.

4. Kōrāre, Tidore; eigenlijke nam van Tidore is Todor.

Het Nuf. verandert de $T$. doorgaans in $k$. en meermalen de $d$. in $r$.

5. De Noefooren gaven in vroeger jaren schatting aan den sultan van Tidore, dien ze als hun heer erkennen.

6. Abra is de algemeene naam voor touw. Met abrakaku (echt touw) wordt bedoeld rotan.

7. Rudia, naam van een plant, welker sap rood is. 
8. Roiram, bladeren van een pandanussoort, waarvan mandjes gevlochten worden. 't Is echter veel te zwak om er prauwen mee op te binden, d.w. z. de uitleggers er aan te bevestigen.

9. P ōk, w.w. kunnen, b.v.n.w. sterk. Wam i pāk, de gewone uitdrukking voor sterke wind, hevige wind.

\section{Ko sma kubur(') ro māsĕn.}

Wōngor ma rōbĕrōk, $\left({ }^{2}\right)$ su fāmfabĕr kukĕr kubur. Wōngor i kin i, ma rōberōk i kākō. Wōngor i pok wer, rjani i d'un kubur be māsěn.

Tauda $\left({ }^{3}\right)$ ro rōběrōk ma ro wōngor, su rwasna, ko mām kāker ro kubur.

7. We vinden de Triton-schelp in zee.

De krokodil en de leguaan twistten beiden om de triton-schelp. De krokodil hield haar vast en de leguaan ook. De krokodil was sterker, daarom nam hij de triton-schelp mee naar zee.

We zien nog aan de triton-schelp de teekenen van de voorpooten van leguaan en krokodil.

1. Kubur, Triton-schelp. De triton-schelp wordt, nadat er een gat in gemaakt is, door de Papoea's gebruikt als trompet, waarop men blaast na wèlgeslaagde sneltocht, of om schuldenaars te manen, hunne schulden te betalen.

2. Rōbĕrōk, lett. ding, dat klinkt. 't Is de Pap. uaam voor tifa. De tifa wordt bespannen met leguanehuid. Vandaar dat de naam rōbĕrōk ook overgegaan is op de leguaan zelve.

3. Als men de triton-schelp in de hand houdt, met de punt van zich af en de opening naar boven, dan ziet men aan de eene, zijde smalle, bruine streepjes, aan den anderen kaut breede, bruine streepen. De eerste zijn naar deze fabel de teekenen van de voorpooten der leguaan, de andere van de krokodil.

\section{Wōnge riob ba.}

Bĕpōn wōnge, man kaku, (') i rob mnis man wēsĕ. Ras ōso, i kukĕr wando, su serf arbon. Bape wonge i d'ores ro snau, aibon na sapi beri, - iririja wando i d'awaw. I běāngār $\left({ }^{2}\right)$ wōnge, d'ōbo: "ku serf aibōn ro sop. $\left({ }^{3}\right)$ Su mbrain ro sop, wando i kofein faro wōnge: "koe pās kum kubena. Aja pas kum bena nabro, wa pās jena." Wōnge kōfein: "i bje"." Bape wando, i pas wōnge kum, riōb be bo, ma wōnge i d'awaw isōf ānsōnā. 


\section{De kasuaris vliegt niet.}

Vroeger was de kasuaris een echte vogel, hij vloog gelijk andere. Op een dag zochten hij en de jaarvogel boomvruchten. Maar als de kasuaris op 'n tak staat, dan vallen de vruchten onmiddellijk. Op deze wijze leed de jaarvogel gebrek. Hij bedroog den kasuaris, zeggende: "Laten we vruchten zoeken beneden". Als ze beneden loopen, zegt de jaarvogel tot den kasuaris: "Laten we onze veêreu uittrekken. Ik zal de uwe eerst uittrekken, trek gij de mijne dan uit." De kasuaris vindt het goed. Maar als de jaarvogel de veeren van den kasuaris uitgetrokken heeft, vliegt hij naar boven, en de kasuaris lijdt er tot nu onder.

1. Mankaku - een echte vogel. De Nufooren tellen den kasuaris niet tot de vogels, "want hij vliegt niet".

2. Bĕangār van 't Mal. akal. Angar is niet altijd bedriegen, 't is ook dikwerf synoniem met slimheid, handigheid.

3. Sōp. In het Nuf. beneden. Op Roon en Meos War, aarde. 't Wisselt af met sup (Nuf. land, bosch. R. plek, plaats).

\section{Diōn ma ēmbĕrōf. (1)}

Diōn i serf in ma royam. Ras ōso i kin ēmbĕrōf, ma ēmběrōf forepĕn diōn, i pōkba i bur. Rub i sja ma, diōn d'ōbo: "Napirmō, wa pir aja!" Bape ēmbĕrōf d'ōbo: "Roba ja kin au sof wa mar. Rub i sar, ma diōn i pōkba rāpe; war i d'ek, i d'ek, isōf diōn i mar.

\section{A a p en ēmbèrōf.}

Een aap zoekt visch en schelpdieren. Op een dag grijpt hij een ēmběrōf en de ēmběrōf omvangt den aap, hij kon nu niet weg. Als de vloed komt, zegt de aap: "Neef, laat me los". Maar de ēmbĕrōf zegt: "Neen ik houd je vast tot ge sterft". De vloed wordt hoog, en de aap kan niet meer; het water stijgt, stijgt, tot de aap sterft.

1. Ēmbĕrōf of $\bar{a} m b$ ĕrōf, een zee-polyp, die veel haar verblijf houdt tusschen de koraalbanken aan de kust en waarop veel jacht gemaakt wordt, daar haar vleesch een gezochte toespijs is.

\section{Mangĕras ma āro.}

Bĕpōn mangĕras i paisĕm ma āro i piupĕr. Ras ōso, maugĕras 
ma āro, su kur bareām, āro d'ōbo: "Ko frur pāugir ro knām kāda, nēri bariām i daf ro māngundi".

Ma āro i disĕn: "Mangakiri daf ro ransun. ( ${ }^{1}$ )

Mangĕras i mēwĕr, d'ōbo: su kar-i bje, su kar, āsēs bjeda i mārārer, i disen: "Metaraja w'or i surupai merawi". ( $\left.{ }^{2}\right)$

Su fāmfabĕr - āro i kin mangěrās, d'āfĕn i ro bariām - māngĕras i piuperr; ma mangĕras i kin āro, piāmpum i ro sausew, aro i paisĕm.

\section{Witte kakatoe en kraai.}

Vroeger was de witte kakatoe zwart en de kraai wit. Op een dag velden de kakatoe en de kraai sagoboomen. De kraai zeide: "Indien wij een gat in den boom maken, zal de sago er van zelve uitvloeien".

En de kraai zong: Mangakiri daf ro ransun. (')

De kakatoe wilde het niet, zij zeide: "t Is beter, dat wij beiden blijven hakken", want dan bewoog haar kam, en ze zingt: "Metaraj w or i surapai merawi." $\left({ }^{2}\right)$

In de daarna volgende twist grijpt de kraai de kakatoe en stopt haar in de sago, waardoor de kakatoe wit wordt en de kakatoe grijpt de kraai en duwt haar in de modder, waardoor de kraai zwart wordt.

1. Dit kraaiengezang liet ik onvertaald, daar 't mij niet geheel duidelijk is. Wellicht stat mangakiri in verband met pangir (opening); daf is uitvloeien; het $\mathrm{ran}$ van $\mathrm{ransun}$ zal wel het Windessische en Roonsche $r$ an zijn voor sago.

2. Ook het lied van de kakatoe is me niet volkomen helder. In metaraj zal tar wel kar (omhakken) zijn en in merawi zal "mer" wel het grondwoord zijn van mararer bewegen. In één van de Nuf. liederen komt dit "mer" nog voor, voor bewegen.

\section{Ingeinus (1) ma Wam.}

Ingeinus, i kein ro āsār snau, i mbri wam barĕk, d'ōbo: "Wam, i pokba i san i ro snau".

Wam barĕk i pōk kāku, ma snau, i mararer be bo, be sop, bape ìngeinus i kīnepĕn a, pākrìk kaku. Wam barĕk, i pōkba i san ìngeinus ro mob bjeda.

Ingeinus i mbri wam murim, d'ōbo: "Wam murim i pokba i san i ro suau bjeda.

Wam murìm i wan mēkĕm i mun $\left({ }^{2}\right)$ rob běsepěr. Arwo, ìngeinus i sjuf ma ori d'ek - ènef $\mathrm{i}$ min $\left({ }^{3}\right)$ ìngeinus ma wam murìm $\mathrm{i}$ 
sjow āwāwen kaku. Ma ingeinus i d'énĕf, i d'èněf kaku, wam murìm i pakbe ōser munda ma îngeinus i sapi.

\section{De ingeinoes en de wind.}

De ingeinoes zit op een waringin-tak, hij daagde den westenwind uit, zeggende: "De wind kan hem niet van den tak werpen!"

De westewind verhief zich met kracht, en de tak beweegt naar boven, naar beneden, maar de ingeinoes houdt zeer stevig den tak vast.

De westewind kan de ingeinoes niet van zijne plaats afwerpen.

De ingeinoes daggt den oostewind uit, zeggende: "De oostewind kan hem niet van zijn tak afwerpen".

De oostewind beveelt den regen den ganschen nacht neer te dalen. 's Morgens is de ingeinoes koud en als de zon stijgt, krijgt de ingeinoes slaap en de oostewind blaast zeer zachtjes. En de ingeinoes slaapt, slaapt, slaapt vast.

De oostewind behoeft maar één maal zich met kracht te verheffen en de ingeinoes valt.

1. Ingeinoes. Naam van een buideldier. Men heeft gevlekte en witte.

2 en 3. Mun en min. Woorden van gelijke beteekenis. De omwisseling van $\mathrm{u}$ en $\mathrm{i}$ in de verschillende Papoesche dialecten komt meer voor. Mun en min beteekenen treffen, slaan, raken, dooden.

\section{As, $\left({ }^{1}\right)$ si sma ārimian( $\left.{ }^{2}\right)$ rariso?}

Bepon As, si fau arimianba, si pāke amin $\left({ }^{3}\right)$ munda. Ras ōso, nāf i barĕk fanām saso $\left(^{4}\right)$ ma i rir rwasi ōso bo rwasi wēsĕ. I nārārer rwasi, As, i kamkam, i swarepĕn, ko frur rariria ro mangarmōm, nēri djadi.

Ma iririja, si frur arimian bepon.

\section{Hoe de As de arimian vonden?}

Vroeger kenden de As de arimian niet, zij gebruikten slechts bamboe. Op een dag, ligt een hond bij de saso. Hij legt de eene voorpoot (kruiselings) op de andere voorpoot. Als hij de voorpooten beweegt, denkt de As, die aan 't smeden was, als we dit zoo van ijzer maken, zal 't gelukken.

En zoo werd de eerste arimian gemaakt. 
1. As. Volgens mijn zegsman naam van de onderdanen van den radja van Salawati.

2. Arimian, IJzeren tang, die bij het smeden gebruikt wordt van bijzonder model.

3. Amin. Bamboe. Doch ook voor dingen, die men er van makkt. Hier wordt bedoeld een omgebogen stuk bamboe in den vorm eener tang.

4. Saso. Naam van de eigenaardige, dikwijls elders reeds beschreven, inlandsche blaasbalg. Ook wordt de geheele smidse met dien naam genoemd.

\section{Ro binsi ma nāfsi.}

Bepon bin, i nai sus na bor; naf, suru munda. Ma bin i sma rumgun fiāk, nāf ōser munda. Bin i kein kukĕr nāf, i kōfein fāro nāf: "Aja, ja mbrein be bo, ma sus na bor jena, si dwark aja-ku fāmfārowe", ma bin i buk sus na bor faro nāf, ma nāf i buk sus suru fāro bin. Rjani bin si sma rumgun ōser ōser munda ānsōua; nāf, si sma na bor.

13. Van vrouwen en honden.

Vroeger had de vrouw vele borsten; de hond slechts twee. En de vrouw kreeg vier kinderen, de hond maar één. De vrouw zittende bij de hond, zegt tot de hond: "Ik loop omhoog en mijne vele borsten belemmeren mij - laten we omwisselen" , en de vrouw geeft de vele borsten aan de hond, en de hond geeft de twee borsten aan de vrouw. Alzóó krijgt de vrouw slechts kinderen éen voor éen; en de hond krijgt er vele.

\section{T'ārukĕn( ( $\left.{ }^{1}\right)$ ma Pasimo. $\left({ }^{2}\right)$}

Snun ōso bin bjedi i mar, i d'erak i kwar.

Ras ōso i d'orĕs ro kubir, i kanĕs suar bin bjedi, i swar i. $\left({ }^{3}\right)$ I kanĕs, bin rwubĕkor i d'ōpĕr be bo. Snun i kāndor, d'ōbo: "Rosei?" Rwubĕkor i kōfein: Wa swar aja, ja jom au, ma snun i mbrein, rwuběhor i titi i jom snunia. I d'ek rum bieda, rwubĕkor i jom i. Rob, bin i běsnunkāku, isua i sjower (4) ro rwubĕkor. Bape snun i mēwĕr i, i san rwubĕkor ro warrwuri. (5) War i d'un rwubĕkor be masĕu. Rwubĕkor i sur, bĕdjadi sra.

Snun bjedi manjowi i kein ro sraia, d'ōbo: Kāmāmo, kāmāmo, s'ekor, si wandōĕn au. $\left({ }^{6}\right)$

Rwubĕkor d'ōbo: Wewe waio, wewewe. ( ${ }^{7}$ ) 
Tārukĕn ma pāsimō, su borĕs, su mam sra, i sur ro bōsen. $\left(^{8}\right)$ Sra ani, suunkakubekor i sur kwar, djadi srahnām. Beponsi s'anba, snaro si fōr $\left({ }^{9}\right)$ sra. Ko mam sra, ko mam mga suru kukĕr snōri, kukĕr sbari kaker.

Tārukĕn kukĕr pasimo, su rama ro sra afuri, su mnaf sra, i kōfein faro su: "Wa kek ja, — pir ja bo. - Pis ja pis Kowuk ba, w'inĕm i msu, w'anik mu." ( $\left.{ }^{10}\right)$

Tārukĕn ma pasimo, su kofein i d'awěs kuker ku. Tārukĕn i pōkba i d'ek, bape pāsimō i d'ek nabje. Pasimo i san sra nakam, i kofein faro tārukĕn : "Wa fandur na". Bape tārukĕn i d'ōrĕn nakām, snēri i fo. Pasimo i sabu, i serf sra, bape tārukĕn i d'ōrĕn nakam.

"I bje kwar!" tārukĕn i kōfein, rariria kwar, ku bur.

Su borěs, pasimo i wan $\left({ }^{1}{ }^{1}\right)$ tārukĕn, d'ōbo: "W'ōpĕr, wa for wau orja !"

Bape wau d'irijaba, aimāndo $\left(1^{2}\right)$ d'irija. Tāruken i d'ōpĕr, aimāudo i min snēri, snēri i mgir, ma sra na kam sapi ro wōndi. Pāsimo i mbrif nāba, andendi kabās (pasimo andendi piōpěr) ma i kerjair tārukěn. $\left({ }^{13}\right)$

Ansōmpe su běfandur sra na kaim ro wai, ma su borĕs be sup, s'un sra faro kāwāsa. Si mārisein bōn ōrně, si ker i rāmuma, ma iriria ansōna k'an sra.

\section{De zeeëgel en de zeekrab.}

Een man, wiens vrouw gestorven was, had haar begraven.

Op een dag staat hij bij 't graf te weenen om zijne vrouw, die hij lief had. Terwijl hij weent, springt het doodshoofd van zijne vrouw naar boven. De man schrikt, hij zegt: "Wat is dit?" Het doodshoofd spreekt: "Gij hebt mij lief, ik volg u!" en waar de man loopt, rolt het doodshoofd hem na, het volgt den man.

De man beklimt zijne woning, het doodshoofd volgt hem. 's Nachts werd het doodshoofd mensch, overdag veranderde het zich in een doofdshoofd. Maar de man wilde het niet en wierp het doodshoofd in de rivier. Het water bracht het doodshoofd naar zee. Het doodshoofd sproot uit, het werd een klapper.

De papegaai van haren man zat in de klapper en zei : "Kamamo, kamamo, s'ek kor, si wandōĕn au."

Het doodshoofd zei: "Wewe, waio, wewewe."

De zeeëgel en de zeekrab waren beiden aan het roeien. Zij zagen den klapper, groeiende op de steenen. Die klapper was een doodshoofd, dat uitgesproten was. De voorouders aten geen kokos- 
noten, want zij durfden ze niet eten. Als wij een kokosnoot bekijken, zien wij twee oogen en een neus en ook een mond.

Als de zeeëgel en de zeekrab onder den klapperboom komen, hooren zij den klapper tot hen beiden zeggen: "Beklimt mij, werpt mij af, schilt mij, splijt mij, drinkt de melk, eet mij!"

De zeeëgel en de zeekrab zeggen: "hij spreekt met ons." De zeeëgel kon niet klimmen, maar de krab klom zeer goed. De krab werpt alle klappers af, en zegt tot den zeeëgel: "Verzamel ze!" Maar de zeeëgel slikt ze alle in, de buik vol. De krab daalde af, zij zocht de klappers, maar de zeeëgel had ze alle ingeslikt.

"t Is goed !" zegt de zeeëgel "nu 't toch zoo is, laten we heengaan!"

Als zij roeien, beveelt de krab den zeeëgel, zeggende: "Spring, vang die schildpad."

Maar 't was geen schildpad, het was drijfhout. Als de zeeëgel springt, dringt het drijfhout in zijn buik, de buik berst en al de klappers vallen naar buiten. De krab lachte hard, haar borst splijt (de borst van de zeekrab is wit) en hij jouwt den zeeëgel uit.

$\mathrm{Nu}$ v̇ergaderen ze de klappers in de prauw, en zij roeien uaar land, zij brengen de klappers tot de menschen. Deze waren blij met deze vrucht, zij plantten ze rondom, en alzoo eten we nu klappers.

A ant. 1. Tarukĕn. Een visch met stekels gelijk de egel en eeu onevenredig dikke buik.

2. Pasimō. Een oneetbare zeekrab.

Dit verhaal hoorde ik gelijk de meeste der in deze blz. opgenomen vertellingen meermalen. Het eerste deel hoorde ik zonder meer vertellen, tot waar tarukĕn en pasimō in het verhaal optreden. Klaarblijkelijk is het eerste en tweede gedeelte echter één verhaal, waarom ik 't bijeengevoegd heb.

Dit verhaal werd ook zoo verteld, dat het met den dood der beide dieren eindigt. De kokosnoten spoelden van zelf aan 't strand en werden door de menschen gevouden.

3. Swar. Lief hebben in 't algemeen. Wordt gebruikt voor medelijden, barmhartig enz. 't Behoort tot de goede gewoonten, dat de gestorvenen, (naar het aanzieu, waarin ze stonden) korter of lauger, met luide klaagzangen worden betreurd.

4. Sjowĕr. Hier vertaald door veranderen. 't Is eigenlijk omhullen. 't Woord is ook sor of sasor. Schoenen b. v. heeten robesasor wesi (dingen, die de voeten omhullen). Ook als fig. in de taal komt het voor in: a p sasor, d. w. z. iemand niet direct 
noemen, maar met 'n bijnaam of vermomd. We zullen dit sjowěr meer in de fabelen aantreffen.

5. W arrwuri. Eenvoudig vert. met water. Eigenlijk is warrwuri lett. vert. hoofd des waters, de brou, oorsprong.

6. en 7. Liet ik onvertaald, daar ik de vert. wel eenigszins vermoeden kan, maar ' $t$ is niet het Nuf. wat nu gesproken wordt en enkele woorden weet ik ook niet. Misschien is het ook z.g. dierentaal, die volgens de fabelen afwijkt van de menschelijke taal.

8. Bōsĕn. De koraalrịffen, die met het land samenhangen en bij laag water bloot komen.

9. Fōr, vertaalde ik als niet durven. Men gebruikt dit fōr eenigszins in de bet. van ta boe. Wanneer iemands familielid ergens gedood is, dan eet hij van die plaats geen enkele vrucht, geen groeten enz. en hij drinkt er geen water. De Nuf. drukt dit uit met fōor robeān Men vreest, als men 't toch eet en drinkt, een ontzettend dikke buik te zullen krijgen en dan te sterven.

Ook is de Nufoor fōr van een weg, een plaats, waar het bloed van een der zijnen heeft gevloeid.

Echter zijn er ook dieren, waar de Nuf. zich fōr voor gevoelt. Er zijn er, die b.v. de kroonduif rekenen tot hun voorouders. Deze zullen geeu kroonduif eten. Van de Wariabsi wordt verhaald, dat ze geen rijst eten, omdat toen hunne stammoeder werd geboren, in de placenta een rijste-aar gevonden werd.

En omdat nu de kokosnoot ontsproten was aan het doodshoofd van een der. voorouders, zou het nageslacht zich ook fōr gevoelen tegenover de kokosnoot. Latere geslachten zouden zich echter van die vrees gëemancipeerd hebben.

10. Ook de vorm, waarin de kokosnoot spreekt, is niet de gewone. De woorden zijn echter duidelijk genoeg, waarom ik 't vertaalde.

11. Wan - zenden. In vele gevallen is dit wan echter ook bevelen. Iets zenden is afnak.

12. A imando. Drijfhout. Algemeene naam voor dood hout, de omgevallen boomstammen b. v. in het bosch. Mar is sterven, marjo ${ }^{1}$ verwelken, verdorren, a i mand o waarschijnlijk 't genasaleerde marjo. Brandhout, 't kleine dood hout heet a miais.

13. Gelijk in de andere dierverhalen, waar de vertelling partij trekt vau eigenaardigheden van sommige dieren, zoo ook hier van de witte borst der zeekrab.

1 J. L. Van Hasselt. Nuf.-Holl. Woordenb. 1893. 


\section{Dewbōki.}

Snungubor ōso i d'arĕm( $\left.{ }^{1}\right)$ Dewbōki, bape i d'ènēf so i baïm Māndira ōso, snungubor ani i d'ek Dewbōki simia, ma i d'ènēf kukĕr i. Ārwo i bur. Bape ino bjeda i sapi ma i min Dewbōki snēri ma Dewbōki i mar.

Isna, Dewbōki suari, kamari s'orĕs, su waf Dewbōki, su swarepĕn i d'ènēf fiōro. Snari, kamari, su wan Dewboki bĕkuìk bjedi i d'or i Běknìk i kōfein: "J'or Dewbōki, i karĕmba; ja mām rik na bor kāku" .

Snari, kamari, su mām Dewbōki, su mām i mar; ma su sma ina ro snēri bjedi.

Su wan womĕn sedi, suōriso Mamintaraja, i serf bĕnai ro ino. Mamìmtaraja i ra be sìngādji, bape sìngādji rumgun bjesi, si fau ino ba; i fukĕn suruān rumgun bjesi dape si kākō si fau ino ba; i fukĕn korano rumgun bjesi, si kako si fau no ba. I fukĕn kapteinlaut $\left({ }^{2}\right)$ rumgun $\left({ }^{3}\right)$ bjedi, i kōfein: "Ino jeda is ōrně".

Dewbōki snari, kamari, s'or kapitein-laut rumgun bjedi, s'ōbo: $\mathrm{Nu}$ nei uei nubedi maroba kwar, ko meōf snun i bĕmun i, i fuōk $\left({ }^{4}\right)$ nei nubedi ro mar.

Rjani: su rir nei bĕmar ro wa, ma suungubor ani $\mathrm{i}$ fnōk nei bĕmar ro wa. Su sissĕn wa kukĕr bori, ma su san wa ro sorĕn $\left(^{5}\right)$ běba.

Ki i d'un wa kukĕr nei bĕmar ma snungubor be meōs. Wa i d'er ōrwa ro krisāfuri. $\left({ }^{6}\right)$

Sjāngi ( $\left.{ }^{7}\right)$ i kein ro krisruri i d'an krisbōn, i san be ro wa kukĕr snungubor ma nei bĕmar.

Rumun ōso, snōriso Bōkibowi, $\left({ }^{8}\right)$ i mām ōrně, i d'or be sjāngi: "Wa san krisbe ro snunkaku rumbori seda awer!"

Sjāngi i mnāf ōrně, i bur.

Rumun i sjuw kajẹn ro wawabni, snungubor i pisak, ma rumun i fukěn i: "Mu serf rosei mob inè?"

Snungubor i faja ro nei i mar, rēsĕri, si rir i kukĕr bin ro wa ma si san wa ro sorĕn bĕba.

Bōkibowi i kōfēn: "Neri ja frur $\left({ }^{9}\right)$ bin, i kenĕm wer, ma Bōkibowi i fandur prim ma i ser prim ro kōmpis $\left({ }^{10}\right)$; wārpur wer i refis sbari ro bin ma $\mathrm{i}$ buk d'inēm prim faro $\mathrm{i}$.

Dewbōki i d'ōren primia, i sfu jar mgasi, d'ōbo: „J'ènēf bĕkwaim kaku". Bāpe snungubor i kōfēn: "W'ènēf, bape wa mar; w'akmām ku kein ro meōs". 
Ma snun i rib wa ro kajĕn kukĕr rōbĕrōk ma snun si borēs, ma wa kāku i sja, kukĕr borěs ( $\left.{ }^{1} 1\right)$ ma rōbĕrōkna, ma su bur be sup seda.

Mānsar ōso, i kein ro rumbrawer ro Dewbōki rumia, ma i kōfēn: "Ja mıāf rōbĕrōk, wa i sja ma". I kōfēn wer: "Dewbōki i rama". Ma rumguusi ro rum, si mbrais. Bape snari i fijow si, d'ōbo: I mām Dewbōki i mar kāku. Aba i kaněs māngĕnēm, si fuāk awer.

Bape wa fanām kwar, Dewbōki snari i mām nei bjedi, i marisein nāba, ma Dewbōki swari, (12) su kein kuker snari, kamari wer.

\section{Dewbōki.}

Een jongeling had zich verloofd met Dewbōki, maar hij had nog niet bij haar geslapen. Op een avond klom die bewuste jongeling in de kamer van Dewbōki en hij sliep bij haar. Des morgen vertrok hij. Maar zijn mes valt en treft de buik van Dewbōki en Dewbōki sterft.

Toen het licht werd, stouden de moeder en vader van Dewbōki op, zij wachten Dewbōki, zij denken, dat zij zoo lang slaapt. Moeder en vader sturen de jongere zuster van Dewbōki, om haar te roepen. De jongere zuster, zegt: "Ik heb Dewbōki geroepen, maar ze antwoordt niet; ik zie zeer veel bloed."

De moeder en vader gaan naar Dewbōki zien; zij zien, dat ze dood is, en ze vinden het mes in hareu buik.

Ze zenden huunen slaaf, wiens naam is Mamintaraja, om den bezitter van het mes te zoeken. Mamintaraja gaat naar den singhadji, maar de volgelingen van den singhadji kennen het mes niet; hij vraagt aan den volgelingen van den soeroehan, maar zij ook, zij keunen het mes niet; hij vraagt aan de volgelingen van den k orano, zij ook, zij kennen het mes niet. Hij vraagt aan den zoon van den kapitein-laut deze zegt; "Dat is mijn mes".

De moeder en vader van Dewbōki roepen den zoon van kapiteinlaut. Zij zeggen tot hem: "Wij hebben ouze dochter niet meer, wij willen, dat de man, die haar gedood heeft, met onze dochter sterft.

Alzoo leggen zij het doode meisje in de prauw, en die jongeling werd gevoegd bij het doode meisje in de prauw. Zij sluiten de prauw met eeu deksel, en zij werpen de prauw in den grooten oceaan.

De stroom brengt de prauw met het doode meisje en den jongeling naar een eiland.

De prauw strandt daar onder een krisboom.

Een zwarte kakatoe zit in den top van den $\mathrm{krisboom;} \mathrm{ze} \mathrm{eet}$ 
kris vruchten en werpt de schalen op de prauw met den jongeling en het doode meisje.

Een varken, genaamd Bokibowi, ziet dit. Het roept tot de zwarte kakatoe: "Gooi geen krisschalen op de daken der menschen woningen".

Als de zwarte kakatoe dit verneemt, vertrekt ze.

Als het varken het zand onder de prauw omwroet, ontwaakt de jongeling en het varken vraagt hem: "Wat zoekt gijlieden hier?"

De jongeling verhaalt van het meisje, hoe het gestorven is en hoe ze hem met de vrouw in de prauw hebben gelegd en de prauw in den grooten oceaan hebben geworpen.

Bokibowi zegt: Ik zal maken, dat de vrouw weer leeft, en Bokibowi, vergadert dauw en giet de dauw in een kopje; later weer brak ze deı mond vau de vrouw open en gaf aan haar de dauw te drinken.

Dewbōki slikte de dauw in, daarna strijkt ze om hare oogen, zeggende: "Ik heb zeer lang geslapen". Maar de jongeling zegt: "Gij hebt niet geslapen, maar ge zijt dood geweest; zie! wij zitten op een eiland".

En de man teekent een prauw in het zand met tifa's en roeiers, en ... een echte prauw is er, met roeiers en tifa's en ze gaan naar hun land.

Een grijsaard zit in de voorgalerij van Dewbōki's huis, en hij zegt: "Ik hoor tifa's, een prauw komt". Hij zegt weer: "Dewbōki komt". En de jongens uit het huis, ze juichen. Maar de moeder verbiedt hen, ze zegt, dat ze heeft gezien, dat Dewbōki echt dood was. En ze weent zeer, opdat ze niet spelen.

Maar als de prauw dichtbij is gekomen, ziet de moeder van Dewbōki hare dochter, en zij is zeer blijde, en Dewbōki en haar man, zij wonen weer met moeder en vader.

A ant. 1. Arĕm. Verloven. De verloofden worden, hoewel nog ongetrouwd, toch als man en vrouw beschouwd. 't Is hun echter niet vergund, elkander te zien, tot aan weerszijden de verplichtingen van den bruidschat zijn nagekomen.

2. Singhadji, Soeroehan, Korano, Kapitein-laut, titels, die de verschillende hoofden voereu. Iedere familie heeft haar eigen hoofd. Een algemeen dorpshoofd kennen de Nufooren niet. En daardoor zijn in én dorp dikwijls verscheidene dignitarissen met weidschen titel bij zeer beperkten invloed.

3. Rumgum. Beteekent zoon, jongen, ook volgelingen. De 
leden der familie, die het gezag van een $\mathrm{Singhadji,} \mathrm{Soeroehan,}$

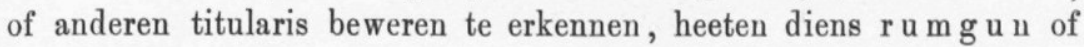
ook romawa.

4. F nōk. Helpen. Ook fn ōw ěk en fnōbĕk. 't Beteekent echter z.a. in dezen zin ook toevoegen, bijdoen. Water bij iets gieten is b.v. ook war i fnōk enz.

5. Sorĕn. Oceaan, de zee. Bedoelt men het zeewater, dan zegt men masēn Inhammen, baaien noemt men sau.

6. Kris. Bekend op Java als kĕtapang, op Ternate als noesoe. De vruchten hebben een harde schaal, de kern wordt als amandelen gegeten.

Krisafuri Onder den krisboom. Afuri beteekent onder den boom.

7. Sjangi. Groote, zwarte kakatoe.

8. Bōkibowi. Dr. Adriani merkte me op, dat bow in het To-radja varken is. $\mathrm{B} \overline{\mathrm{k}} \mathrm{ki}$ is de bekende titel voor prinsessen. Dus prinses varken is de lett. vert.

9. Frur. Maken. Dit frur wordt echter ook gebruikt voor 't behandelen van zieken en gewonden.

10. K $\overline{\mathrm{m}} \mathrm{p}$ is. 't Verbasterd holl. woord kopje.

11. Borĕs. Roeispa an. Wordt echter ook gebruikt ten opzichte van de roeiers zelve.

12. De jonge man is verplicht na de huwelijksvoltrekking een jaar ongeveer verblijf te houden in 't huis zijner schoonouders.

\section{Nuri.}

Ro Rumbĕrpōn ( $\left.{ }^{1}\right)$ ikāk ōso, snōri Nuri. I buk bin suru, māmbĕnaik. $\left({ }^{2}\right)$ Su snōsna: Kaidusĕrai ma Insirisinēj. Rās ōso si pōs in. Nuri i mēwĕr in, i mārisein roiām. $\left({ }^{3}\right)$ Bape bin, su mkak i māngěnēm, snar ikak. Bin, su borěs, Nuri i d'as $\left({ }^{4}\right)$ i ro wa raundi, $\left({ }^{5}\right)$ rwuri frāk $\left({ }^{6}\right)$ ro wa andiudi. $\left({ }^{7}\right)$ I mam in, roiam, i d'arōn fasau, i d'un be bo.

I mam kapirare, bin, su mēwĕr; su mām āb $\left({ }^{8}\right)$ běba, bin, su kōfēn: "W'un i, i ba". Rēsĕri rwuri i sabu ro māsĕn dōri, i mārisein i d'un āb krafia, ab i piamuk ( $\left.{ }^{9}\right)$ Nuri rwuri. I mar, krāf i ra be sup, i d'ek ro Ainei. $\left({ }^{10}\right)$

$\mathrm{Si}$ disen ( $\left.{ }^{1} 1\right)$ : Nuri dōnduwē, $\left({ }^{12}\right)$ mōswuarō, $\left({ }^{13}\right)$ Anai bonbesajaiondi, $\left({ }^{14}\right)$ i $\operatorname{piar}\left({ }^{15}\right)$ i d'awaw, naimawasi $\left({ }^{16}\right)$ muswaro. $\left({ }^{17}\right)$

\section{Nuri.}

Op Rumberpon bezat een slang, wiens naam was Nuri, twee $7^{\circ}$ Volgr. VII. 
vrouwen, zusters. Hun beider namen waren : Kaiduserai en Insirisinej. Op een dag gaan ze visschen. Nuri houdt niet van visch, hij wil schelpen. Maar de vrouwen vreezen hem zeer, omdat hij een slang is. Terwijl de vrouwen roeien, ligt Nuri opgerold op de voorplecht. 't Hoofd legt hij op den kant der prauw, en als hij een visch of een schelp ziet, duikt hij spoedig en brengt het naar boven.

Als hij een kleine schelp ziet, weigeren de vrouwen; maar toen zij groote ab zagen, zeggen de vrouwen: "Haal die, die is groot". En toen daalde het hoofd in zee; hij wilde het vleesch van de ab halen, maar de ab knelde het hoofd vau Nuri af. Terwijl hij sterft, gaat het lichaam naar land, en bestijgt de Ainei.

Ze zingen: Nuri roept den vloed, zij hebben 't eiland lief, de Anei is een berg met ver uitzicht, het land onder water, hij in nood, meisjes bemint hem!

A a nt. 1. Rumberpon. Eiland, op de kaarten genoemd Amberpon. De overleveringen beweren, dat door een watervloed dit eiland zou gescheiden zijn van de vaste kust. Aan deze catastrophe sluit de legende van Nuri zich aan.

2. Manbenaik. Naik is in 't algemeen broeder, familielid, stamverwant. Mambenaik is broeder in den beperkten zin, dien het woord bij ons heeft. Hier ook zuster.

3. Roiām. Schelpdieren. Wordt bepaald de schelp, de schaal bedoeld, dan wordt gezegd: roi āmbe.

4. As. Oprollen van touw of koperdraad. Hier 't opgerold liggen van een slang.

5. Wa raundi. Door letterverspringing van wa a urndi, a ur of ur, kin. Waraundi dus het voorste gedeelte van de prauw.

6. Fiāk. 't Hoofd neerleggen. Afiak is naam van de bekende hoofdsteunsels, de houten bankjes, waarop de Papoea het hoofd te rusten legt.

7. Āndindi. Kant, grens (van andir).

8. $\overline{\mathrm{A}}$ b. Groot schelpdier, kan de grootte van meer dan $50 \mathrm{cM}$. bereiken, sluit zich als de oester.

9. Piamuk, pam uk. Uk is scheiden. Kar of ker uk, door suijden van elkander scheiden, pa m uk, door drukken van elkander scheiden. Hier afknellen.

10. A inei. Berg op Rumberpon.

11. Op de Nufoorsche zangpartijen wordt deze historie met de volgende woorden bezongen. 
De meeste liederen, die gezongen worden met woorden in niet alledaagsche vormen, hebben verklaring noodig.

12. Dōnduwe, door nasaleering en samenstelling ontstaan uit d'or rub. Or rub wordt ondub. B. en W. wisselen z. a. bekend veelmaals. $\mathrm{Or}$ is roepen, $\mathrm{rub}$ is vloed.

$\mathrm{D} \overline{\mathrm{n}} \mathrm{d}$ u we $=$ d'or $\mathrm{rub}=$ hij roept den vloed (de overstrooming).

13. Mōswuaro. Het eiland, dat geliefd wordt.

14. Bōnběsajōndi. Bōn is berg. Sajor, dat op Windesi de beteekenis van zien in 't algemeen heeft, beteekent in het Nuf. vèr zien, uitzicht hebben. $B \bar{o} n$ bĕsajor wordt door nasaleering bōnběsajōndi - een berg met ver uitzicht, een hooge berg.

15. Piar. Drijven. Het eiland drijft weg.

16. Maimawasi $-\mathrm{Mai}=$ meisje, mawa is klein. $\mathrm{Naima-}$ wasi in het Nuf.: jonge meisjes in tegenstelling van romawasijongens.

17. Muswaro. Heb lief. Hier staat naimasi in het gew. meerv. terwijl mu swaro, in den dualisvorm staat.

\section{Ingu. ( $\left.{ }^{1}\right)$}

Nufor, si bores be Rain. $\left({ }^{2}\right)$ Ōso ro si, i mar ro Rain, ma s'erak i. Snun bĕṃar snōri bjedi Morìmpi.

S'erak i ro swan, ingu ōso i rama, ma i d'un snun bĕmar rwuběkor, $\left({ }^{3}\right)$ i d'ōrěn i.

I d’ōrĕn i kwar, in i jar $\left({ }^{4}\right)$ ro Rain be Mnsowerr, $\left({ }^{5}\right)$ ro Mnsowĕr be Sārāwāti, ro Sārāwāti, be Doreri, ro Doreri be Nufori.

Ingu i jar fanām rum, i d'or: "Mèsēer wa waf aja ro der.

Ro rum, si kāndor, si kōfēn: Mundiri i d'awēs ōrja.

Bape mėser kawāsa, si waf ro der, ingu i rama, i d'au Morimpi rwuběkor ma Morimpi snari i d'un i fa i d'erak i ro Nufori.

Inga kajōb $\left({ }^{6}\right)$ bjeda: Nōt ani irja werwainapi wariwa si sari, nōt āmbe sasĕr $i$, si wer $i$, s'un be rusora, s'un $i$ be rum ani irja wer.

Mani akako do manjofai.

Manjofai sawanko ranuri i sar, i ra d'un susa nairo si sar, i mun ambendira, Not ani irja wer wainapi wariwa si sari, not ambe saser i, si wer i, s'un be rusora, si weriwe wer $i$ wa be rum ani irja wer. 


\section{Ingu.}

Nufooren roeien naar Ceram. Eén van hen sterft op Ceram en zij begraven hem. De naam van den doode was Morimpi.

Zij hadden hem aan 't strand begraven. Een in g u komt en neemt het doodshoofd van den gestorven man, en slikt het in.

Toen ze 't ingeslikt had, zwemt ze van Ceram naar Misol, van Misol naar Salawati, van Salawati naar Doré, van Doré naar Nufoor.

De ing a zwemt dichtbij het huis en roept: "Wacht me morgen, als 't ebbe is."

In het huis, waren ze verwonderd, en ze zeggen: "Wie spreekt daar?"

Maar den volgenden dag wacht het volk, toen 't ebbe was, de ing u komt, ze braakt 't doodshoofd van Morimpi uit; de moeder van Morimpi neemt het en begraaft het op Nufoor.

Het lied van de·ingu: De rijstzak, die ze medenamen naar het vreemde land, de zak, die de vreemdelingen gevuld hebben, die ze over de schouders gehangen hebben, ze brengen die naar het kerkhof, ze brengen die naar het huis weer.

Het lied Manjofai der voorouders: Sawankoranuri is gegaan naar het vreemde land, hij gaat en hij brengt droefheid mee, ze zijn gegaan in de richting van het vreemde land.

De rijstzak, die ze medenamen naar het vreemde land, de zak, die de vreemdelingen gevuld hebben, die ze over de schouders gehangen hebben, ze brengen die naar het kerkhof, ze brengen, die naar het huis weer.

A a nt. l. Ingu. De naam van een groote visch. Men vertelt er zelfs van, dat deze visch prauwen aanvalt.

2. Raïn. Ceram. Vau ouds bestaan er handelsbetrekkingen tusschen de Papoea's en de Cerammers. De geregelde bootdienst vermiuderde de prauwvaart. Een enkele maal hebbeu echter nog tochten naar het vreemde land (de a mber) plaats, doch tegenwoordig doorgaans niet verder dan naar Salawati.

Terwijl iemand voor 't eerst op reis is naar de "a mber", worden door de achterblijvende familieleden zangpartijen georganiseerd, om hem te beschermen tegen de booze invloeden van geesten. Die zangpartijen hebben onder den naam van "dis ĕn wārk" ook plaats, wauneer iemand voor 't eerst naar een plaats op Nieuw-Guinea 
zelve gaat, maar de feesten voor hen, die naar de "amber" gaan, hebben meerdere nachten plaats en de liederen, die dan gezongen worden, zijn herinneringen aan voorvaderen, die dezelfde tochten deden.

3. Rwubĕkor. Doodshoofd. Kor is been. Rwubĕ kor, het beenig gedeelte van het hoofd.

4. Ja r, Zwemmen, n.l. 't zwemmen van visschen. 't Zwemmen van menschen, schildpadden, krokodillen, viervoetige dieren is a s.

5. Mnsowĕr. Nuf. naam van Misol.

6. Kajōb. Zang, n.l. de zangen ter eere van de dooden. Vooral worden deze gezongen bij 't maken der korwars (beeldjes, voorstellende de vooronders).

Gelijk de meeste liederen, is ook dit in niet alledaagsche, waarschijnlijk wel oudere vormen. De vert. in het Holl. is ook niet letterlijk. In de liederen komen dikwijls vergelijkingen voor, vermonde woorden.

$\mathrm{Nōt}$ is hetzelfde als nōken (zak, gevlochten van bladeren); wainapi, naam van de soort nōkĕn; wariwa, die kant, ginds; si sari, sar is scherp - overdrachtelijk is sar ook snel varen gelijk het scherpe mes snel doordringt, in 't Holl. — ze snijden er van door; wer over de schouders hangeu; s aser, vullen; rus, kerkhof, plaats waar de graven (kubir) zijn.

Het lied is eene herinnering an de reis en het doel er van. 't Wordt de ingu in de mond gelegd.

Op zoo'n zangpartij zingt het eene deel de ingu-partij, terwijl het andere deel het lied der voorouders zingt. A k a ko, voorouders, wordt nu vervangen door bĕpōnsi; mun is het gedeelte; a mbendira, het genasaleerde a mber.

\section{A siōk sarāk. (')}

Rās ōso kāpāl Ingris i d'ajujĕn fanām rirbor. $\left({ }^{2}\right)$ Kapitein jongons $\left({ }^{3}\right)$ bjedi i ban asiōk fanām āwawejĕk. $\left({ }^{4}\right)$ Asiōk sarāk i sapi. Kaptein i msor naba. Jongons i mkak ma mẻsĕr i pāke sānsun běbje ma i d'orĕs ro awawejĕk. I mām sāroj ( $\left.{ }^{5}\right)$ fanām kapāl, i fukĕn: "w'un aja be rirbor". Bape sāroj d'ōbo: "Ja jar ro bo munda, ja pōkba, ja jar be sōp" . I mām ingōmbararì,,$\left({ }^{6}\right)$ i fukĕn ingōmbarerē, i d'un i be sōp, bape ingōmbararē i mēwěr kakō, d'ōbo i jar ro bo munda. Jongons i i mām ingu, i d'or ingu, i d'un i be riror; ingu d'ōbo: "i bje !" Ma jōngōns i kein ro ingu kruri ma ingu $i$ d'un $i$ be rirbor. 
Jōngōns i mām kēru romāntar, $\left({ }^{7}\right)$ - ōrnĕ faknīk $\left({ }^{8}\right)$ rum bieda, ma ingu i d'or faknik, i sibĕr āsiōk faro jōngōns. Faknìk d'ōbo: "Mundiri kōfēn, aja nei āsiōk". Ingu d'ōbo: "Au, wa nei i baboi, ja mām i kwar, ma wa siběr asiōk ba, ja serf rum wēsě".

Ro kēru romāntar ani, sim suru; ōso faknik bjeda, sumindi $\left({ }^{9}\right)$ ingu bjeda. Ingu i d'awĕs rariria, faknik i sibĕr asiōk, bape asiōk brawĕn ma i buk sansun běbje kaku, ma jōngōns i d'ek kapal wer kukĕr āsiōk brawĕn ma sānsun běbje. Kāptein i kāndor, d’ōbo, i kāptein ba kwar; jōngōns i bĕdjādi kāptein.

\section{De zilveren lepel.}

Op een dag voer een Engelsch schip bij een koraalbank. De bediende van den kapitein wiesch de lepels bij de trap. De zilveren lepel viel. De kapitein was zeer boos. De bediende vreest en morgen kleedt hij zich met mooie kleederen en hij staat op de trap. Als hij een walvisch bij 't schip ziet, vraagt hij: "Breng mij naar de koraalbank!" Maar de walvisch zegt: "Ik zwem slechts boven, ik kan niet naar beneden zwemmen!" Hij ziet een bruinvisch, hij vraagt aan de bruinvisch, hem naar beneden te brengeu. Maar de bruinvisch weigert ook, ze zegt, ze zwemt slechts boven. De bediende ziet een ingu, hij vraagt de ingu, hem naar de koraalbank te brengen; de ingu zegt: "'t is goed!" En de bediende zit op den rug van de ingu en de ingu brengt hem naar de koraalbank.

De bediende ziet eeu grooten steen, - dat was het huis van een zeegeest, en de ingu vraagt aan de faknik den zilvereu lepel aan den bediende terug te geven. De faknik zegt: "Wie zegt, dat ik den lepel heb". De ingu zegt: "Welzeker, hebt gij die, ik heb het gezien, en als ge den lepel niet teruggeeft, dan zoek ik een ander huis".

In dieu grooten steen waren twee kamers; éen van de zeegeest, de andere van de ingu. Toen de ing u zoo sprak, gaf de faknik den lepel terug, maar een gouden lepel en ze gaf zeer mooie kleederen, en de bediende besteeg het schip weer met den gouden lepel en de mooie kleeren. De kapitein was verbaasd, hij zei : nu was hij geen kapitein meer en de bediende werd kapitein.

A a nt. 1. Sārāk. Zilver, ook zilveren armring. In het Roonsch is $s \bar{a} r \bar{a} k \bar{a} n$, zonneschijn.

Prof. Kern.: Over de verh. v/h Maf. tot de Mal. Pol. talen 
(blz. 261), zegt: Sarak. Natuurlijk het Amb., Bulusche, Daj. Jav. salaka, Sang. sadaka, zilver.

2. Rirbor, ook rirwor. Koraalrif, in zee. Koraalrotsen en riffen, die met de kust sameuhangen, heeten $b \bar{o} s$ ĕn.

3. Jōngōns. 't In Indië welbekende, verbasterd Holl. jongen, algemeene naam voor bediende.

4. $\bar{A}$ wàwejĕk. Ook a wēk, trap. De eerste vorm verduidelijkt de afleiding. A wa w'ejek, hout, gij beklimt; a w'ek, a w'ek, ook: hout: gij beklimt.

5. Saroj. Potvisch, kleine soort walvisch. Op sommige tijden van het jaar komen deze dieren veel voor in de Nieuw-Guineesche wateren.

6. Ingōmbararē, Bruinvisch.

7. Romanter. Groot, reusachtig.

8. Faknik. Zeegeest. Van de faknik gelooft de Nufoor, dat deze de stormen veroorzaakt. Ze leven naar de Nuf. beweert in de rotsen en holen.

9. Sumindi. De andere, de er op gelijkende; waarschijnlijk: su mnis.

\section{Korano ( $\left.{ }^{1}\right)$ Rōbĕfrar. $\left({ }^{2}\right)$}

Korano Rōbĕfrar, i bĕprēnta faro karau munda. I māma suunkaku ro swan, si sma in si bor, i snarĕm, si kun in, i kōfein: "I bje, kāwāsa, si sma in, rōb, ko ra ko karau in".

Ōrja $\left({ }^{3}\right)$ i wan kāwāsa rōběfrar, si sabu. Oso i d'ejĕk $\left({ }^{4}\right)$ rum. Rēsěri $\left({ }^{5}\right)$ si rafa, $\left({ }^{6}\right)$ snunkaku si warĕn kaker, s' enĕfba. Si bur fa si kōfein faro Korano Rōběfrar si kōfein: Tāndirima, $\left({ }^{7}\right)$ tāndirjama, ārēte tākarēte, tarare ta wapi, si ōni oni (Kawāsa s'enĕf baïm, si wārĕn-binatang woos seda).

$\bar{A}$ nsōna, si kein. Mānānur sani $\left(^{8}\right)$ i wan fa s'ek rumia, si mām wer. Si rafa, snunkaku ani s'enĕf kwar. Si rama, si kōfein faro Korano Rōběfrar ro wos seda. $\left({ }^{9}\right)$ Tāndirima, tāndirjama, ārēte, tākārēte, tārārēta wapi, s'enēpa, nēpa".

Mānānur i wan, s'un in si kām.

Ārwo kāwäsa s'ibĕr si, si sma in ōsoba, s'un in kām.

Ōrja rōb wer, snunkāku, si kōfein: "I bje kwar, $\left({ }^{10}\right)$ rōb ko mām, snun mundiri i karau in. Si sin roi běkārau ōrja. Rōběfrar s'ek, si kiu in, kāwāse, si kōfein: "Korano Rōběfrar kawāsa bjesi, si karau in. Si min ōno, ōno si bur.

S'awēs ( ${ }^{1}$ ) Korano Rōběfrar, s'ōbo: "i prēnte nabjeba". 


\section{Koning Muis.}

Koning Muis gaf bevelen (had te gebieden) aan dieven siechts.

Eens ziet hij, dat de menschen van het strand vele visschen hadden; als hij ruikt, dat ze de visch rooken, zegt hij: "Goed, de menschen hebben visch, van nacht gaan we visch stelen."

Daarop zendt hij het muizenvolk, zij dalen af en éen beklimt het huis. En toen gingen ze weg, want de menschen waakten nog, zij sliepen niet. Ze gaan heen om 't aan Koning Muis te zeggen. Ze zeggen: "Tāudirima, tāndirjama, ārēte, tākārēte, tārārēta wapi, si ōni ōni!" (In beestentaal: "De menschen slapen nog niet, ze waken)."

Zij wachten, tot hun aanvoerder hun 't bevel geeft, het huis te bestijgen om weer te zien. Als ze nu gaan, slapen de menschen. Zij komen en ze zeggen aan Koning Muis in hunne taal: "Tāndirima, tāndirjama, arēte, tākārēte, tarareta wapi, s'enēpa, nēpa." (In muizentaal: ze slapen al).

Als des morgens de menschen ontwaken, zien zij geen enkele visch, alle visschen zijn weggehaald.

Daarop, 't wordt weer nacht, zeggen de menschen: "heden nacht zullen we zien, wie er visch steelt."

Ze loeren, wie er zal komen stelen. De muizen klimmen op, ze grijpen de visch. Nu zeggen de menschen: "Het volk van Koning Muis, zij zijn de vischdieven". Eenigen worden gedood, eenigen ontkomen.

Ze verwijten Koning Muis, dat hij geen goede bevelen geeft.

Aant. l. Korano. De bekende Moluksche titel Kolano. Gelijk al vroeger is opgemerkt, beteekent onder de Nufooren de ééne titel niet 'veel meer dan de andere.

2. Rōbĕfrar. Muis. (lett. ding, dat hard loopt).

3. Ōrja. Als aanw. v.n.w. beteekent het die, gindsche, in tegenstelling van deze, dit. Bij het verhalen gebruikt men het in de bet. van: daarop; toen dit was geschied; dit alzoo zijnde enz.

4. Gĕh of ek, klimmen.

5. Rēsĕri. Wordt ook bij het verhalen telkens gebruikt voor : en toen, daarna enz.

6. $\mathrm{Rafa}$. Gaan in de richting van den spreker af, rama gaan in de richting tot den spreker.

7. Tāndirima enz. Het hier volgende liet ik onvertaald, daar deze muizentaal geen begrijpbaar Nuf. is. Mijn verhaler voegde er 
tot uitlegging bij: "Dat is beestentaal en beteekent: "De menschen slapen nog niet, ze waken nog." W a pi is misschien w a $\mathrm{f}$ - wachten.

8. Sa ui. Samentrekking van sedi (bez. v.n.w. hun) en a n i (aanw. v.n.w., bedoelde, de bewuste enz.). De bet. is dan "hun aanvoerder, over wien we reeds spraken" of "dien we reeds kennen" enz.

9. Uit het nu volgende muizentaaltje is alleen te begrijpen: enёpa, en ĕf (slapen).

10. Ibje kwar. Uitdrukking voor: "Er is niets meer aan te doen", "'t is gebeurd" enz. Lett. is het: 't is goed."

1I. Awĕs. Spreken. Wordt echter z. a. in dezen zin ook gebezigd voor: tegen iemand uitvaren, iemand berispen.

Wordt alleen bedoeld: spreken met iemand, dan voegt men achter aw ĕs nog kukĕr met. Volgt onmiddellijk achter awĕs het voorw., dan heeft aw ĕs de bet. van berispen enz.

\section{Mānsasĕrworìndi.}

Ikak ro Nufori, snōriso Mānsasĕrworìndi.

Bĕpōn ikak i min snunkaku ba, i d’ènĕf (1) kukĕr snōn bĕnei i. Māmbĕnaik di suru. Bĕba, snōri Bawe, bĕkanìk Māmbōki.

Bawe i buk bin sāmfur sissĕr suru. Bawe i borěs, Māmbōki i mēwěr, i kein ro rum.

Ōrja Bawe, i kōfein faro ikak Mānsasĕrworìndi : "Māmbōki i mēwĕr, wa mām wārk $\left({ }^{2}\right) \mathrm{i}$; i frur pērkara $\left({ }^{3}\right)$ kukĕr bin ōso, i d'awĕs kukĕr i - wa fes su kaïm".

Ōrja Māmbōki i frur pērkara, i d'awĕs kukĕr Bawe swari ōser.

Bawe i bur be rum, bin sāmfur sîsĕr ōser, si kakes ( $\left.{ }^{(}\right)$i, s'un berĕn faro i. Bawe i mām kāusa (5) samfur sissěr ōser, kakes oser i sia ba. Ōso i mar ke, i frur pērkara ke? I wan romgun bjedi, i d'un sumber ro wai kukĕr kēru. I jas sumber, fa i sar kaku. I pref swābōr, kum ro krāf bjedi, ro wesi. I mam, i sar kaku kwar.

I sjun ro sim, bin i frur pērkara, i mam Mambōki kukĕr bin, ma ikāk piarĕk su. I mam, pierĕm $\left(^{6}\right)$ si, pierĕm ikak, i muk. Snōn, i mar, bin, i mar; ikak rwwri i kenēm wer. I bur, i sāpi ro masēn, i d'as ro rumĕraundi, i bur, i kubur. $\left({ }^{7}\right)$ "Mgo mun aja rē, $\left({ }^{8}\right)$ ja sin, ja mun mgo munda". Ansōna i bĕmbrōb snunkaku.

Bĕpōu raririaba.

20. Mānsas ĕr rorîndi.

Op Nufori was een slang, genaamd Mānsaserworíndi. 
Vroeger doodde de slang den mensch niet, hij sliep met den man, die zijn eigenaar was.

Er waren twee broeders. De oudste heet Bawé, de jongere Mamboki.

Bawé had twaalf vrouwen. Bawé ging roeien, Mamboki wilde niet, hij bleef thuis.

Daarop zei Bawé tot len slang Mansaserworindi: "Mámboki weigert mee te gaan, let goed op hem; als hij een perkara makt met eene vrouw, als hij met haar praat - bind hen beiden!"

Daarop maakte Bawé eene perkara, hij praatte met ééne "van Bawés vrouwen.

Toen Bawé naar huis vertrok, onthaalden elf vrouwen hem, ze brachten hem pinang. Bawé ziet elf koperen borden, één onthaal was er niet. Wellicht was er een dood, wellicht had die eene eene perkara gemaakt? Hij beval zijnen zoon, het hakmes uit de prauw te halen en den steen. Hij sleep het mes, opdat het zeer scherp was. Hij schoor er den baard mee, en het haar van het lichaam en van de beenen. Hij ziet, dat het zeer scherp is.

Toen hij het vertrek binnen ging van de vrouw, die de perkara gemaakt had, ziet hij Mamboki met de vrouw, en de slang omstrengelde hen beiden. Als hij dat ziet, hakt hij er op los, en hij hakt de slang in stukken. De man sterft, de vrouw sterft; de kop van de slang leeft weer. Deze gaat heen, en valt in zee. Hij zwemt langs de voorzijde van het huis; en heengaande blaast hij op de tritonschelp en zegt: "Gij hebt mij het eerst geslagen, ik zal nu aldoor maar u dooden. " $\mathrm{Nu}$ beoorloogt hij den mensch.

Vroeger was het aldus niet.

A ant. 1. Enĕf. Slapen. Ook de beteekenis van verblijf houden.

2. Mām wārk. Opletten. Samengest. uit mam, zien, en wark, beletten. 't Heeft de bet. van: nauwkeurig iemand nagaan.

3. Pērkara. .'t Bekende Mal. woord voor rechtzaak, quaestie enz. Frur pērkara, een perkara maken, iets doen, wat tot een perkara anleiding geeft.

4. Kakes. Onthalen. Voornamelijk wordt bedoeld het onthalen op tabak en pinang. 't Behoort tot de gewoonten, die eene rechtgëaarde vrouw in acht moet nemen, dat ze den echtgenoot, die van eene reis wederkeert, met tabak en pinang tegentreedt, als hij uit zijne prauw het huis van de zeezijde inklimt. Wanneer eene 
vrouw in dezen te kort schiet, is dit voor den man een reden te denken, dat er iets aan hapert.

5. Kansa. Koper. Ook alle artikelen, die van koper zijn gemakt, als schalen, pinangdoosjes enz. Hier worden bedoeld de koperen borden of doozen, waaruit de vrouwen hunne tractatie den wedergekeerden echtgenoot aauboden.

6. Pier ĕm of i perĕm. Hij slaat met het hakmes. V.b. van de invoeging van het v.n.w. v./d. $3^{\mathrm{e}}$ pers. in het w.w.

Naar oud-Nufoorsche adat moeten man en vrouw, die betrapt worden op overspel, door den beleedigden man wordeu gedood en vooral in eene zaak als deze, waar de man nog wel een broer is van deu echtgenoot. Dit geldt als bloedschande.

7. Kubur. Tritonschelp, de schelp, waarop het sein voor den strijd enz. gegeven wordt. Ook het blazen op de kubur, wordt kubur genoemd.

8. Rē. Waarschijnlijk rēsěri, eerst.

\section{Abrabōn. (1)}

Snun Makasar i frur rum afĕr, $\left({ }^{2}\right)$ bape i fanba i frur bo pāngir abrabōn. Abrabōn i ba kaku - snunkaku i kapirare.

Ma s'ènĕf ro rum, māndira kam, abrabōn ani i sasiar, ma i d'ārk ōso ro kawāsa rum, ma snun i mar. Iriria i d'ārk siwke, samfurke. Kawāsa si bor bur rumia, ma rum i bro.

Snun Bugi i rama kukĕr kāpal bjeda, i serf rum. Kawāsa kām, si meofba snun. Bugi i kein ro rum sena. Bape snun, i benei rum ibro ani, i kōfein faro snun Bugi: "Wa marisein, wa kein ro rum jeda, wa kein wauerik, bape ja kein paik siw, snun siw, si mar, rjani ja bor bur rum orja". Snun Bugi i kofein: "I bje, ja bĕsewa rum bani wauerik.

Rōb bĕpōn, suun Bugi i wàrĕn. I mām binatang ani i rama, i frar kukĕr kawāsa bjeda be kapal, ma i d'ènĕf ōrwa.

Rob běsuru i d'un tuwale $\left({ }^{3}\right)$ ōso, ma i waf ro kērwa. Binatang i rama, i san rōběan faro i, iriria binatang i sia fa faro i. Si mām biuatang aui, mgasu $\left(^{4}\right)$ sak imnis padamara.

Binatāng fanām kaku, suun Bugi i san tuwala ro rwuri binatangia ma i d'un bur mga bjesu.

Binatāng i msor, i jom. Bape i jom ōso, wēsĕ i mbrein nejān wēsě ; i jom i wer, ōso i mbrein nejān wēsĕ wer. Iriria i mbrein papiar māngenēm. Ma snun i d'un mgasu, i d'ek kāpal kukĕr kawāsa bjedi ma i bur beri. 
Arwo suun benei rum ani, i pisah, i mam abrabōn bĕmar, i kōfein: "Biuatāng ro rum jani is ōrnĕ, Bugi i d'un bur $\left({ }^{5}\right)$ mgasu. Si jom snun Bugi, bape si sma $\mathrm{i}$ ba kwar.

Snun Bugi, i sma untung bĕba kukĕr mga brawĕn su, bape benei ro rum, i sma rum munda.

\section{Duizendpoot.}

Een Makassaar makte een steenen huis, maar hij wist niet, dat hij het maakte boven 't hol van een duizendpoot. 't Was een zeer groote duizendpoot - een mensch was er klein bij.

En als zij in het huis sliepen, kwam die duizendpoot naar buiten, en hij beet een van het volk uit het huis, en de man stierf. Zoo had hij er misschien negen, misschien tien gebeten. Het volk verliet het huis en het huis was leeg.

Een Boeginees kwam met zijn schip, hij zoekt een huis. Niet een van het volk wilde, dat de Boeginees in zijn woning verblijf hield. Maar de man, die het ledige huis bezat, hij zegt tot den Boeginees: "Wilt ge in mijn huis wonen, woon er dan maar, maar ik heb er negen maanden gewoond en negen mannen zijn gestorven, daarom heb ik dat huis verlaten.". De Boeginees zegt: "'t Is goed, ik huur dat huis van u maar."

Den eersten nacht waakt de Boeginees. Als hij dat beest ziet komen, vlucht hij met zijn volk naar het schip en hij sliep daar.

Den tweeden nacht neemt hij een hoofddoek mee, en hij wacht aan de deur. Toen het beest $\mathrm{kwam}$, werpt hij het voedsel toe, alzoo ging het beest tot hem. Zij zagen, dat de beide oogen van dat beest vlamden als een lamp.

Toen het beest zeer dicht bij was, wiep de Boeginees den hoofddoek op het hoofd van het beest en haalde de beide oogen weg.

Het beest werd boos, en achtervolgde hen. Maar als hij er een achtervolgde, liep een ander een anderen weg; liep hij dezen na, dan liep er weer een een anderen weg. Daardoor liep hij te verward. En de man, die de beide oogen had weggehaald, besteeg het schip met zijn volk en hij vertrok onmiddellijk.

Des morgens ontwaakt de bezitter van het huis eu hij ziet den dooden duizendpoot. Dan zegt hij: Dit is het beest uit mijn huis. De Boeginees heeft de beide oogen weggehaald. Zij achtervolgden den Boeginees, maar zij vonden hem niet meer.

De Boeginees had groote winst met de beide gouden oogen, maar de eigenaar van het huis had alleen het huis. 
A ant. 1. Abrabōn. Duizendpoot. Abra is touw, maar tevens de algemeene benaming van alles, wat tot binden dient, ook rotan en de lianen. Deze slingerplanten dragen peulvruchten. B o $\mathrm{n}$ is vrucht, abrabon lett. lianenvrucht of wel peulvrucht. En nu heeft de duizeudpoot door zijne geledingen werkelijk wel eenige overeenkomt met een peulvrucht.

2. A fer. Kalk. Rum a fer, lett. kalken huis, de benaming voor steenen woningen.

3. Tuwala. Gewoonlijk zegt de Nuf. twara voor hoofddoek. Tuwala is het algemeen in de Molukken verbreide woord. Port.: toalha, Eng. towl.

4. Algasu. Zelden hoort men dualisvorm voor oogen. Hier valt er echter den nadruk op, dat beide oogen vlamden, van goud waren, meilegenomen worden enz.

In het volgende verhaal speelt eeu slang een rol, die goud in de keel had. Slangen, die schitterende steenen en paarlen bij zich hebben, zijn, naar sommigen beweren, meermalen gezien(?)

5. Un bur. Samengest. uit un (halen) en bur (weggaan); un bur, weghalen.

\section{Snun miskin. $\left({ }^{1}\right)$}

Ro mēnu ōso, snun miskin, i kein kukĕr swari.

$\mathrm{Su}$ miskin kaku, su kein ro rum kaku maroba, ma robĕan, su bĕfandur i mnis mangkōkō. $\left({ }^{2}\right)$ Rosei kawāsa s'an, su j'an.

Swari bjedi i pas abris ro radja diaf bjeda; i sma pipi( $\left.{ }^{3}\right)$ sāmfur di suru. Snun i bĕmāngābo $\left({ }^{4}\right)$ nabjeba kaku, i pōkba fārarur.

Rās ōso rādja, i wan kawāsa, si frur $\left(^{5}\right)$ wa sena, insaro si serf aimgan $\left({ }^{6}\right)$, kesi $\left({ }^{7}\right)$ ma samgawa $\left({ }^{8}\right)$ fa si bědakām.

Kāwasa kām, si bur, snun bĕmiskin ani kukĕr swari, su j’awaw. Ma snun, i kōfein faro bin: "Wa mbrein be buta $\left({ }^{9}\right)$, wa kobis bjēf ma amion (1") faro pipi samfur di suru. Ku jom kawāsa.

Bin, i frur wa. I rir āmbafēn, insaro snun i barek, snari bĕmāngābo. Ma su bur, su jom kāwāsa. Su sma kāwāsa ro swapōr. ( $\left.{ }^{1}{ }^{1}\right)$ Kāwāsa, si mām suun bĕmiskin, swari, su rama, si jau su.

Suuu bĕmiskin, i bur, i kọ̄ein faro bin: "Kāwāsa, si jau ku, ku bur". Su bur, su barĕk ro swan. Su fnap robĕan ker kaku ro urĕn kapirare kaku. Ma su serf sāmgawa ma aimgan, karìng sāmfur, snar mob ōrwa i bow (12) kaku.

Māndira fnurèp kaku, ikak ōso, romāntār kaku i d'anawĕr be swan. Ikāk ōrně i nei brawěn ro sāsuri, ma snun ma bin, su mam, 
i fnāk kuker brawĕn ani. I mawāb sbari, brawĕn i sasiar, ma i sua mob i kwaim, ma ikak i sjob be dōri wer.

Bin i mkak, i kin snun, d'ōbo: "Ku ro ke? Ku ro ke?" Snun, i kōfein: "Wa mkak awer, ku ro maroba."

Snun i swar brawĕn ōrnĕ, i swarepĕn ro suēri: "Ja nei kada, j’awaw ōsoba kwar!"

Ikak, i bur wer be mob bjeda.

Bape rās wēsě, snun, i bur, i kōfein faro bin : "Wa kein ro wa, ja mbrein knik!"

I mām ikak nejān bjeda, i jom i, isōf i mām ikak dōrē bjeda; i kein waf ikak.

Māndira wer, ikak i sāsiar. Snun, i mam i, i kein fasis kāku: Ikak i fnāk brawĕn bjeda wer. Snun, i mām ōrnĕ, i sjob tuwala ma i rir tuwala ro sāprōp. Brawĕn, i sāsiar ikak sbari, i sapi ro snun miskin tuwala bjeda. Snun, i pāngum fasau, ma i frar. Ikak, i jom i. Bope snun, i frar fasau, ikak i sma i ba.

Ikak, i snēri sām, i mararer sup běsipĕr, tatewai ma wamdōfer is min sup.

Kāwāsā ro swāpōr, si kandor, s'ōbo: "Snun, bin miskin, su j'an roi sāsar ke?" $\left({ }^{13}\right)$

Suun i d'āfĕn brawĕn ani ro mēk bjeda, ma i borĕs be kāwāsā wēsě.

Māndira, kāwāsā, si pām padamara, s'an robĕan seda. Si kĕrjar suun bĕmiskin, s'ōbo: i d'an roběan bjeda ro fnurēp. "I bje", snun, i kōfein, "aja miskin, rjani j’an robĕan jeda ro fnurēp; mgo, mg'an ro isna." Bape s'an kam, snun, i bas mēh bjeda, ma kāwāsā, si kāndor, snaro isna běba.

Māndira wer, rariria wer. Si kōfein: "Snun bĕmiskin i d'uu rosei ?"

Māndira ōso, rumgum kapirare i d'ōf fanām snun bĕmiskin; i mam, suun, i bas mēk bjeda; isua běba. I kōfein faro kāwāsa: "Isna bĕba i sia ro snun miskin wa dōri".

Radja ro mẹ̄nu ōrja, i mnāf, i d'or snun bĕmiskin; i marisein, i kobis brawĕn ōrnĕ. Snun miskin, i mēofba.

Kāwāsa, si serf aimgan ma sāmgawa ma kesi imnis, si bur be mēnu seda wer.

Snun ma bin miskiu, su kein ro wa seda, ma māndira wer, i bas mēk bjeda ma isna $\mathrm{i}$ ba wer. Radja ro mēnu bjeda, $\mathrm{i}$ fukĕn: "Rosei is ōrnĕ, isna bĕba so?" Si kōfein: "Suun bĕmiskin i d'un brawĕn!"

Radja i d'or i, snun i mēwĕr, d'ōbo: i miskin, i māngabo bjeda 
kaku, i mkak i ra faro radja. Radja, i d'or běsuru, bĕkiōr. Ānsōna snun bĕmiskin i ra faro radja. Radja i marisein is kobis brawĕn ōrně. Snun miskin, i meōf ba. Bape radia, i kōfein : "Ja buk rum sāmfur faro un ifo kuker ārta. Ānsōna snun i marisein.

Iriria suun bĕmiskin i sma ārta na bor kaku. Warpur wer, i bĕdjadi radja ro sup ōrně, ma rās ōso, i kōfein faro swari : "Bĕpōn ku miskin, ānsōna ko sma arta na bor. Mundiri i buk ōrnĕ kām maro ku? Wa mām be bo!"

\section{De arme man.}

In een dorp woonde een arme man met zijne vrouw. Ze waren zeer arm, ze woonden niet in een echt huis, en hun voedsel verzamelden ze als de kippen. Wat de menschen aten, dat aten zij ook. Zijne vrouw wiedde gras in den tuin van den radja; zij ontving daarvoor twintig centen. Die man had in hevige mate mengabo, hij kon niet werken.

Op een dag, beval de radja aan zijn volk, dat ze hunne prauwen zouden in orde brengen, opdat ze kanarinoten, dammer en notemuskart zouden zoeken om te handeleu.

Toen alle menschen vertrokken waren, zaten die arme man en zijne vrouw in nood. En de man zeide tot de vrouw: "Ga naar de markt, koop pisang en djamboes voor de twintig centen. We volgen de menschen."

De vrouw makte de prauw in orde. Zij legde een plank, opdat de man zou kunnen liggen, omdat hij mengabo had. En ze vertrokken, ze volgden het volk na. Zij vonden het volk aan de kaap. Het volk ziet den armen man en zijne vrouw ziende, joegen hen beiden weg.

De arme man, hij gaat weg en hij zegt tot zijne vrouw : "Als ze ons wegjagen, dan gaan we weg". Als ze zijn vertrokken, liggen ze aan het strand. Ze koken zeer weinig eten in een zeer kleine aarden pot. En ze zochten notemuskaat en kanarinoten, tien zakken, omdat op die plaats zeer veel was.

Den avoud, 't was zeer donker, kroop een reusachtige slang naar het strand. Die šlang had goud in de keel, en die man en vrouw, ze zagen hem spelen met dat goud. Als hij den mond opelideed, ging het goud naar buiten en het gaf zeer ver licht, en de slang trok het weer naar binnen.

De vrouw vreesde, ze greep den man vast, ze zeide: "Gaan wij verloren? Gaan we verloren?" De man zeide:" Wees niet bang, we gaan niet verloren". 
De man beminde dit goud, hij dacht in zijn hart: "Als ik het had, verkeerde ik in geen enkelen nood meer".

De slang ging weer naar zijne plaats.

Maar den anderen dag ging de man heen, hij zeide tot de vrouw: "Blijf in de prauw, ik wandel een weinig".

Hij ziet deu weg van den slang en hij volgt dien, tot hij het hol van den slang ziet; dan gaat hij op den slang zitten wachten.

Toen het weer avond werd, kwam de slang er uit. Als de man hem ziet, zit hij zeer stil. De slang speelde weer met zijn goud. De man, dit ziende, trekt zijn hoofddoek en legt den hoofddoek op den grond. Toen het goud uit den mond van den slang kwam, viel het op den hoofddoek van den armen man. De man pakte het gauw in en hij vluchtte. De slang achtervolgt hem. Maar de man liep hard, de slang kreeg hem niet.

De slang, die zeer boos werd, bewoog het geheele laud, het land werd getroffen door aardbeving en storm.

Het volk aan de kaap schrikte, zij zeiden: "Zouden de arme man en vrouw iets verkeerds hebben gegeten".

De man stopte dat goud in zijn bladeren koffertje, en hij roeide naar het andere volk.

Des avonds, staken de menschen hunne lampen op, toen ze hun voedsel gingen opeten. Ze jouwden den armen man uit, zeggende: "hij eet zijn voedsel in duisternis". "t Is goed", zeide de arme man, "ik ben arm, daarom eet ik mijn voedsel in het donker; gijlieden, ge eet bij licht". Maar, terwijl ze allen aan 't eten waren, maakte de man zijn koffertje opjen, en al het volk was verbaasd, wegens het groote licht.

En den volgenden avoud weer. Ze zeiden: "Wat heeft de arme man meegebracht?"

Op een avond verborg zich een kleine jongen in de nabijheid van den armen man; hij ziet den man zijn koffertje openen; het werd zeer licht. Hij zeide tot het volk: "'t Groote licht is in de prauw van den armen man".

De koning van dat dorp het hoorende, roept den armen man; hij wil dat goud koopen. De arme man wil niet.

Als het volk genoeg kanarinoten en notemuskaat en dammer hadden vergaderd, vertrokken ze weer naar hun dorp.

De arme man en vrouw, bleven beiden in hun vaartuig, en des avonds opende hij weer het koffertje en het werd weer zeer licht. De koning van zijn dorp vroeg: 
"Wat is dat, dat groote licht?" Men zeide: "De arme man heeft goud meegebracht!"

De koning roept hem, de man weigert, hij zegt: hij is arm, hij heeft in hooge mate mēngābo, hij vreest tot den koning te gaan. De koning roept de tweede maal, de derde maal. Nu gaat de arme man tot den koning. De koning wil dit goud koopen. De arme man wil niet. Maar de koning zegt: "I $\mathrm{k}$ geef $\mathrm{u}$ tien huizen gevuld met schatten". $\mathrm{Nu}$ wilde de man wel.

Aldus ontving de arme man zeer vele schatten. Later werd hij koning van dat land, en op een dag zeide hij tot zijne vrouw: "Vroeger waren we arm, nu hebben we vele schatten. Wie heeft dit alles aan ons gegeven? Zie naar boven!"

A ant. 1. Miskin. Arm. Uit het Maleisch overgenomen.

2. Imnis Mangkōkō. Zooals de kippen, d.w.z. ze zochten evenals de kippen her en der hun voedsel, en aten hetgeen de anderen hadden weggeworpen of wat van hun maaltijd was overgebleven.

3. Pipi. Cent. Op Halmaheira in 't algemeen de naam voor geld. (V. Baarda: Galélareesch-Holl. Woordenb. blz. 323).

4. Mēngābo. Nuf. naam voor de ziekte, die in de Mol. bobento heet. Framboesia tropica. De inlanders zien graag, dat kinderen deze ziekte hebben, want dit vrijwaart hen later voor lepra, z. a. ze beweren. Maar ouderen van dagen zijn er bang voor, daar het dan ongeneeslijk schijnt en de ledematen verstijven doet.

5. Frur is maken, maar ook z.a. hier in orde brengen, repareeren, herstellen. Zoo ook voor behandeling van zieken en gewonden.

6. A imga n. Kanarinoot. Komt op N. G. niet veel voor.

7. Kesi. Dammer. gom. copal. Voornaam handelsart. van N. G.

8. Sāmgawa. Notemuskaat. Een inferieur soort komt hier en daar tamelijk veel voor op N. G.

9. Buta. Het Tid. woord voor markt.

10. Amiōn kan beteekenen djamboe, maar ook de op Java bekende ketoepa's (rijst gekookt in gevlochten bladeren).

11. Swa pōr. Kaap. Eene kleine bocht in het land raris.

12. Bow. 'k Vond dit woord in mijn manuscript. 'k Heb verzuimd bij 't neerschrijven de bet. te vragen. Wellicht is 't ook een schrijffout en moet het bor zijn, veel. Ik heb 't als bor vetraald.

$7^{\circ}$ Volgr. VII. 
Su j'an roi sāsar ke? Zie aant. 9 van $\mathrm{N}^{\circ} 14$. Het eteu van iets, dat $\mathrm{f} \overline{\mathrm{r}} \mathrm{r}$ is, heeft immer treurige gevolgen voor den schuldige.

Maar aan nog iets kan gedacht worden. An nabje, goed eten, is fig. gebruikt, zich fatsoenlijk gedragen. 't Is mogelijk, dat men vermoedt, dat die arme menschen iets gedaan hebben, wat niet in den haak is, en dat de natuur zich daarover vertoornd toont. Het plegen van bloedschande b.v. wordt naar de meening der Nuf. gevolgd door verwoestingen door aardbeving enz. Meermalen werd mij door Nuf. nadat ze gehoord hadden van de aard- en zeebeving op Ceram, als hunne meening gezegd, dat iemand zich daar aan bloedschande zou hebben schuldig gemaakt.

\section{Nei ro bejĕn nijew.}

Ras ōso, snun i mbrein ro sup, i serf robĕan. I rama fanām bejĕn nijew. Snari i bur, i frar. Bape i mnāf, ōso kianěs; i swarepĕn bejĕn mgun, bape i serf, i mām nei kapirare, i d'un i be swan. Snun aui, swari su, su nai rumgun ba. Ānsōna su fan nei ro bejĕu nijew. Kepursi (') ro nei ōrně si sia kaker.

\section{3. 't Meisje uit het varkenshol.}

Op een dag ging een man naar het bosch om eten te zoeken. Hij komt dicht bij een varkenshol. Het moeder-varken loopt hard weg. Maar hij hoort huilen; hij denkt dat het 't jong van 't varken is; maar zoekende, vindt hij. een klein meisje, dat hij meeneemt naar het strand. Die man en zijne vrouw hadden geen kind. $\mathrm{Nu}$ voedden zij het meisje nit het varkenshol op. De nakomelingen van dit meisje zijn er nog.

A a nt. 1. De bewering af te stammen van een krokodil, kroonduif enz. is in 't geheel niet vreemd onder de Papoea's.

\section{Nei ro ikak.}

Ikak ōso i bĕmgu snunkaku, nei d'iria. Ma i d'un i be diaf, nei ōrnĕ i d'an biêf. Benai ro diāf, $i$ for nei ōrnĕ, ma i d'un i be rum. Warpur i buk i, ma i sma nei wer.

Nei ōrně, i so kamari be diāf. Ikak ani, kepuri bjedi, i mām i, i reb (') i. Kamari i mām ōrně, i perĕm ikak, i mar. I rama ro rum, i kōfein faro swari : "Rās inè knìko ikak i d'ōrĕn nei bedi, bape ja perĕm i, i mar. Ānsōna bin, i mbrein be diāf, i mām ikak, 
swari bjedi i perĕm kwar, ma i d'āfĕn snari bjedi ro nōkēng, i d'un $\mathrm{i}$ be rum.

\section{De dochter der slang.}

Een slang had een mensch ter wereld gebracht, een meisje. En zij bracht haar naar een tuin, waar dit meisje pisang at. De bezitter van den tuin ving dit meisje en nam het meê naar huis. Later huwde hij haar, en hij kreeg weer een meisje.

Dit meisje volgde haren vader naar den tuin. Die bewuste slang, hare grootmoeder, zag haar, ze likte haar. De vader, dit ziende, slaat de slang dood. Tehuis komende, zegt hij tot zijne vrouw: "Vandaag had een slang bijna uwe dochter ingeslikt, maar ik heb ze doodgeslagen." $\mathrm{Nu}$ ging de vrouw naar den tuin, ze ziet de slang, die haar man heeft gedood, en ze doet hare moeder in een zak, ze brengt ze naar huis.

Aant. l. Reb, likken. De slang maakt door zijne prooi eerst te belikken, deze glad en daardoor meer geschikt om in te slikken. Hier was echter dat likken waarschijnlijk vriendschappelijk bedoeld.

\section{Soèk (1) kukēr Kōrwēn. $\left({ }^{2}\right)$}

Soēk, si barēk ro Meōsnomi. $\left({ }^{3}\right)$ Rōb s'enēf, ikak kōrwēn, i snarĕm for, i d'anawer be swan, ma i reb Soēk ōso ma i d'ōrĕn i. Soēk ani, i nei sarabi $\left(^{4}\right)$ ōso. Ikak i d'ōrĕn snun kwar, i d'anawer wer be sup. Aimando i barek, ikak i d'anawer ro bo, Soēk i d'uu sarabi bjeda ma i kna ikak snēri. Soēk, i sāpi ro rwa ōrně : ikak, i mar, i sapi ro rwa ōrwa.

Ārwo Soēk, si pisak, si serf bati sedi. Si dor i fanām aimāndo, ma si kin i kukĕr undaim, $\left({ }^{6}\right)$ isōf i pōk $\left({ }^{7}\right)$ wer.

\section{De Soëkker en de reuzenslang.}

De Soëkkers lagen op Meosnomi. Toen zij 's nachts sliepen, kroop een reuzenslang, die het vuur geroken had, naar het straud, en hị likte een Soëkker en slikte hem in. Die Soëkker had een mes. Toen de slang den man had ingeslikt kroop hij weer naar het bosch. Een omgevelde boom lag er; de slang kroop er over heen, en de Soëkker neemt zijn mes en snijdt de buik van de slang open. De Soëkker valt aan dezen kant, de doode slang valt aan de andere zijde.

Des morgens ontwaken de Soëkkers, zij zoeken hunnen vriend. 
Ze vinden hem bij den omgevallen boom, en ze betasten hem met bladeren, tot hij weer krachtig was.

A ant. 1. Soēk. Eiland, dicht bij Biak. De bewoners der verschillende eilanden en landstreken, worden met den naam hunner woonplaatsen genoemd.

2. Kōrwēn. Tot welk geslacht of welke familie deze slang behoort, is mij onbekend. Ik vertaalde het als reuzenslang, daar że volgens de beschrijvingen van respectabele grootte zijn.

3. Mēosnōmi of Meos Num. Eiland dicht bij Jowbi. Dit Meōsuomi is niet bewoond. Naar de Papoea's beweren herbergt het vele slangen.

4. Sa rabi. Mes van eigenaardigen vorm.

5. Undarm. Bladeren. Bladeren dienen den Papoea's veel bij het behandelen van hunne zieken.

\section{Tobēlo(') ma ikak.}

Tobelo ōso i mbrein ro Meōsnōmi, i sapi ro dōrē. Ikak mgun, si swarepĕn sna sedi, s'ek ro i. Snari i d'anawer, i serf robĕan. Āmber ōrja, i marisein i bur, bape i pōkba i d'ek, suaro dorē imnis ārsēn āmbafēn. $\left(^{2}\right)$ Ikak snari, i sïber wer. Āmber ani, i mam ikak, i kin tuwala bjerla, ma i waf ikak i sabu. Ikak i sabu, purari bĕpōn.

AAnsōna āmber i kin purari kukĕr tuwala bjeda. Ikak i snēri sām, i mararer purari be bo ma i san iriria āmber kako be bo. Amber i frar, bape ikak i jom i. Amber, i běāngār $\left({ }^{3}\right)$ i, i san kēru be nejān wēsĕ. Ikak i jom sasar keru, bape knīko i jom suun wer; i san wer kēru, isof i rama ro swan, i mbrein ro māsĕn Ikak i mkak war, i kandor, i bur.

\section{De Tobelorees en de slang.}

Een Tobelorees liep op Meōsnōmi, hij viel in een kuil. De jonge slangen dachten, dat het hunne moeder was, en zij klommen tegen hem op. De moeder was weggekropen om eten te zoeken. Die vreemdeling wilde weg gaan maar hij kon niet klimmen, omdat de kuil was als een muur van planken. De moederslang keerde weer. Als die vreemdeling de slang ziet, houdt hij zijn hoofddoek in de hand en hij wacht tot de slang neerdaalt. De slang daalt neer, de staart vooruit.

$\mathrm{Nu}$ houdt de vreemdeling den staart vast met zijn hoofddoek. 
De slang wordt boos, ze beweegt den staart naar boven en werpt aldus den vreemdeling ook naar boven. De vreemdeling draaft weg, maar de slang achtervolgde hem. De vreemdeling bedriegt haar, hij werpt een steen naar een anderen weg. De slang achtervolgt verkeerdelijk den steen, maar dadelijk achtervolgt hij weer den man; hij werpt weer een steen, tot hij aan 't strand komt, toen liep hij in zee.

De slang was bang voor het water, ze schrok en ze ging heen.

A a nt. 1. Tobelo. Plaats op de Oostkust van Halmaheira.

2. Arsen ambafen. Plauken wand. De wanden van den kuil waren glad, gelijk een planken wand.

3. Bĕāngār. Bedriegen van het Mal. a kal.

\section{Bin, snēri bĕba, ikak, i d'ōrĕn i.}

Snun ma bin, su farbuk kwar. Bin, i snēri bĕba. Rās ōso s'om diaf. Ma māndira, s'enĕf. ikak korwĕn, i rama; i reb bin, ma i d'ōrĕn i kukĕr rumgun bjedi; rēsěri ikak i bur.

Ārwo, snun, i serf bin; i mam ikak, i d'un i. I d'or kāwāsa ma si jom ikak. Si sma i, si kna snēri bjedi. Si sma bin, bape i mar kwar. Ānsōna si kna bin snēri kakō, ma rumgun, i kenĕm kaker. S'un i, si fan i, isōf i ba.

\section{De zwangere vrouw, die door een slang werd ingeslikt.}

Een man en vrouw waren gehuwd. De vrouw werd zwanger. Op een dag ontginden ze een tuin. Des avonds, terwijl ze sliepen, kwam een reuzenslang; hij likte de vrouw, en hij slikt haar in met haar kind; en toen ging de slaug heen.

Des morgens zoekt de man de vrouw; hij zag, dat een slang. haar heeft weggehaald. Hij riep het volk bijeen en zij achtervolgden den slang. Als ze hem vinden, snijden ze hem den buik open. Zij vinden de vrouw, maar ze was dood. Nu suijden ze de vrouw den buik ook open en het kind leeft nog. Zij nemen het mee, ze voedden het, tot het groot was.

\section{Kiūof( $\left.{ }^{1}\right)$ bĕba.}

Mankarikadi, i sjowĕr $\left({ }^{2}\right)$ i ro kinōf bĕba. I ra faro Korano, i nai nei sāmfur. I d'or ōso, fa i buk i. Bĕba, $\left({ }^{3}\right)$ si mēwer kam, si buk $\left({ }^{4}\right)$ in. Bĕknìk, i marisein. Isna Mānkarikadi i sjowĕr ro kinōf, rōb, i běsnunkaku. 
Rōb ōso, i kun bur ( $\left.{ }^{5}\right)$ kinōf pisja, d'ōbo: i marisein, isna, swari, su mbrein, su borĕs.

Mānkarikadi, i borěs paik di fiāk. Běba, si msor bĕknìk, s'ōbo: si buk Māukarikadi kaim. Bĕba, si san bĕknìk ro faknìk, $\left({ }^{6}\right)$ bape i mar ba.

Mānkarikadi, i bur ( $\left.{ }^{7}\right)$ wer, bin wēsĕ kām, si buk roběan, berĕn $\left({ }^{8}\right)$ faro $i$, bape $i$ mēwer. I mām swari bjedi ba, $i$ fukĕn : "Bin jedi roriso?" S'ōbo, si fau i ba, i bur be sup, si serf $i$ fiōro kwar.

Mānkarikadi, i kofein : "Mgo srer, mgo mun i kwar!"

Bin, si kōfein, i buk si kam kada! I kōfein : "Roba, ja marisein ōso ro mgo ba, ja marisein bĕknìk mgobedi i jer" .

I ra, serf i, i sma i, i d'un i wer, i kein so i munda.

\section{De groote Kinof.}

Mankarikadi veranderde zich in een groote $\mathrm{k}$ in of. Hij gaat naar den korano, die tien dochters had. Hij vroeg er één, om haar te trouwen. De ouderen weigeren allen, een visch te trouwen. De jongste wil wel.

Overdag veranderde Mankarikadi zich in een kinof, des nachts was hij mensch.

Op een nacht verbrandde de vrouw den kin of huid, ze zegt: ze wil overdag met haren man wandelen, roeien.

Mankarikadi ging vier maanden roeien. De ouderen waren boos op de jongste, ze zeggen, dat ze allen Mankarikadi trouweu willen. De ouderen wierpen de jongste op een faknik, maar ze stierf niet.

Toen Mankarikadi weer kwam, gaven de andere vrouwen hem voedsel en pinangnoten, maar hij weigerde. Hij ziet zijne vrouw niet, en hij vraagt: "Waar is mijue vrouw?" Zij zeggen dat ze haar niet weten, ze is naar het bosch gegaan, ze hebben haar al lang gezocht.

Mankarikadi, zegt: "Gij liegt, ge hebt haar gedood!"

De vrouwen zeggen, dat hij haar allen huwen mag! Hij zegt: "Neen, ik wil niet één vau $\mathrm{u}$, ik wil uwe jongste zuster, haar alleen".

Hij gaat haar zoeken. Als hij haar vindt, brengt hij haar weer mee en hij blijft slechts bij haar.

A ant. $1 \mathrm{Kin} \overline{\mathrm{f}}$. Een visch.

2. Sjowĕr. Veranderen, vermommen, zie aant. 4 van $\mathrm{N}^{\circ} 14$. 
3. B ӗba. Groot. Onder broers en zusters worden de ouderen bĕba genoemd, de jongeren worden door hunne ouderen bĕkn ìk genoemd. De vrouw van Mankarikadi was ten opzichte van al hare zusters de b̆̌knik.

4. Buk. Huwen. Eigenlijk beteekent buk, geven. In den zin van huwen, ook zich geven. Elkander huwen is farbuk. Far geeft aau een w.w. een meerv. beteekenis.

5. Kun bur. Samengesteld uit kun, branden, en bur, weggaan, dus door branden 't weg maken.

6. Faknik zie aant. 8 van $\mathrm{N}^{0} 18$. Hier wordt de woonplaats bedoeld van de zeegeest. Die woonplaatsen worden ontzien, men nadert die niet en vaart er stilzwijgend voorbij,

7. Bur. Vertrekken, weggaan, een plats verlaten. Gewoonlijk onderscheidt men bur fa en bur ma. 't Eerste van de woonplaats naar elders vertrekken. Bur ma, vertrekken naar de woonplaats.

8. Zie over dit gebruik aant. 4 van $\mathrm{N}^{\circ} 20$. Dat aanbieden van tabak enz. (kakes) geschiedt door de echtgenooten. Het aanbieden van tabak en pinang door vrouwen aan mannen en omgekeerd, wanneer ze niet gehuwd zijn, is een stilzwijgende uitnoodiging tot geslachtsgemeenschap.

\section{9. (1) Bin ro berĕn ruri. $\left({ }^{2}\right)$}

Binia kor rās di suru kwar; i wan faro snōn běkāmkāmia, $\left({ }^{3}\right)$ i wan mangarpis $\left({ }^{4}\right)$ faro snōnia, ma knîko, suōn i kam wef i. $\left({ }^{5}\right)$ Mangarpis, i kōfein faro i : Īnsĕrĕn $\left({ }^{6}\right)$ jedi, i wan aja, d'ōbo: "Mèsĕr, wa rafa ro war, wa masi ani. Ma snōn, i ra, bin ani, i sabu ro berĕnia ruri faro $i$, su j'èněf. Ma bin bĕpōn, i serf i. Ma arwo, i d'or ( $\left.{ }^{7}\right)$ fa si kāmkām wēr.

Ma i kāmkām kwar, i d'asĕr $\left({ }^{8}\right)$ bin ba, d'ōbo: i masi.

Ma i mgirba, $\left({ }^{9}\right)$ i d'ènĕf rōb di suru; ānsōna $i$ bur faro bin bĕpōu. Ānsōna, i kōfein faro bin běpōn, d’ōbo: "Bin jedi i sia ro asaria furi. Ma bin bĕpōnia, i ra fa i serf i, bape i sma i ba. Ma i kōfein: "Ja sma i ba !" Bape snon, i kōfein : "Isia". Ma ānsōna suōn, i kōfein faro bin běkon ro berĕnia ruri : Wa fāsna mangundau faro i. Ānsōna, i fāsna i faro bin běpōn. Ānsōnā, bin bĕpōn, i d'un i, fa $\mathrm{i}$ kein so i ro rum bjeda.

Ma snōn ani, i bores, bin bĕkein ro berĕnia ruri ani, i sma rumgun. Ma bin běpōn, i d'āfĕn i ro nökēn, ma i san i. Mboi i d'âfĕn kāmkām, ārimian, roibĕjowěr $\left({ }^{1}{ }^{0}\right)$ ro nōkēn, insaro i fāsna faro snōnia. Ma i mun kakō rumgunia snari, bape mangirio i d'un 
rumgunia kuker snari, su, fa i frur su. Ma su bur faro rum subeda, ìs ōrnĕ berĕnia ruri. Ma snōnia, i rama, bin bĕpōn, i fasna munara snōnia bjana faro i. Ma snōnia, i kōfein : "I bje kwar, māndira ko fnāk sārma ( $\left.{ }^{1}{ }^{1}\right)$.

Ma rumgun ani, i ra fa i d'akfnak. Ma i fnāk nabje kaku. Ma kāwāsa s'or i fa i d'akan berĕn, bape i mëwĕr. Ma si kōfein ōrnĕ faro kamari. Ma kamari kōfein : "Mandira iné, ja rafa j’akmām mānsěrēn $\left({ }^{12}\right)$ mundiri is ōrja. Ma i ra, i d'akmām.

Si fnāk wer, rumgun ani, i rama. Ma i fnāk nabje kaku. Ma kamari i kein ro karapēsa $\left({ }^{1}{ }^{3}\right)$ bjeda.

Ānsōna i d'or i, fa i d'akan kakes, bape i sibĕr kruri fa i kjar kamari. Ma ānsōna kamari i māmbadir ( $\left.{ }^{4}\right)$ i. Ma i kōfein : Rumgun jedi irja. Ma rumgun ani, i bur wer faro snari. Ma arwo, kamari, i wan kawāsa faro i, bape i kofein: "Roba, ja rafaba, snar bin bĕpōnia i san aja kwar ma i jabĕk sna jedi ro rumbri babia, (15) rjani ja rafaba. Mboi ja rafa, kamari i wan bin bĕpōnia fa $\mathrm{i}$ bur. lriria snon ani, i jau bin bĕpōnia, fa i bur.

\section{De vrouw in den top van den pinangboom.}

De vrouw had twee dagen geteld, toen ze een honigzuigertje tot den smid zond. Bijna had de man dit met zijn hamer dood geslagen. Het honigzuigertje zeide tot hem : "Mijne meesteres heeft mij gezonden, ze zeide: "Ga morgen naar die rivier, waar ge u gebaad hebt." En de man ging, en die vrouw daalde uit den top van den pinangboom tot hem, en ze sliepen beiden. En de eerste vrouw, ze zocht hem. En 's morgens riep hij weer zijne helpers om te smeden.

En toen hij gesmeed had, ging hij niet met zijne vrouw mede, hij zei, dat hij ging baden.

En hij kwam het bosch niet uit, twee nachten sliep hij er; daarop ging hij naar zijne eerste vrouw. $\mathrm{Nu}$ zeide hij tot zijne eerste vrouw: "Mijn vrouw is onder den waringinboom". En de eerste vrouw, ze ging om haar te zoeken, maar ze vond haar niet. En ze zeide: "Ik vind haar niet". Maar de man zegt: "Ze is er !" En nu zegt de man tot de vrouw, die in den top van den pinangboom zat: "Toon u zelve aan haar". Nu toonde ze zich aan de eerste vrouw. $\mathrm{Nu}$ neemt de eerste vrouw haar mede, opdat ze met haar in haar huis zou wonen.

En terwijl die man roeiende was, kreeg de vrouw uit den top van den pinangboom een zoon. En de eerste vrouw stopte hem in 
een zak en wierp hem weg. Ja, ze deed den hamer, den nijptang, den kauwbijtel in een zak, om aan den man te toonen. En ze doodde ook de moeder van den jongen, maar een boschkip haalde den jongen en zijne moeder beiden, en ze behandelde hen beiden. En zij gingen naar hun beider huis, dat is de top van den pinangboom. En toen de man kwam, toonde de eerste vrouw zijne gereedschappen aan hem. En de man zeide: 't Is goed, van avond spelen we 't sa rma-spel.

En die jongen kwam ook om mêe te spelen. En hij speelde zeer goed. En 't volk riep hem om mee pinang te eten, maar hij wilde niet. En ze zeiden dit tot den vader. En de vader zei : "Van avoud zal ik gaan om te zien welke heer dit is." En hij gaat, om mee te kijken naar het spel.

Als ze weer aan 't spelen zijn, komt die jongen. En hij speelde zeer goed. En de vader zit op zijn stoel.

$\mathrm{Nu}$ roept hij hem, om mee te eten van het onthaal, en hij draaide om, om zijnen vader den rug toe te keeren. En nu ziet de vader hem nauwkeurig aan. En hij zegt: "Dat is mijn zoon!" En die jongen ging weer naar zijue moeder. En des morgens zendt de vader volk tot hem, maar hij zeide: "Neen, ik ga niet, omdat de eerste vrouw mij heeft weggeworpen en zij heeft mijne moeder onder het huis gebondeu, daarom ga ik niet. Ja, ik ga, als mijn vader de eerste vrouw wegzendt." En alzoo, joeg de man de eerste vrouw weg.

Aant. 1. Dit verhaal ontving ik in manuscript van een mijner Papoesche kweekelingen. Ik gaf het weer z.a. ik het ontving. Volledig is het echter niet, n.l. 't begin niet. 't Vangt aan met de mededeeling, dat er eene vrouw was, die voortgekomen was uit den top van een pinangboom, waar ze na hare wording verblijf hield. Van daar uit bespiedde ze een smid, die gewend was in een riviertje te baden.

2. Ruri. Top van een boom. Ook widom is top, maar dan de uiterste punt. Men spreekt b. v. van sra-widom, d.i. het weeke uiteinde. $\mathrm{Ruri}$ is echter het geheele bovenste gedeelte.

3. Bĕkāmkāmia. Kāmkām is smeden. $K \bar{a} m$ is overg., eischt een voorw,, b. suwber (hakmes). Kāmkām is smeden in 't algemeen. $\mathrm{S} n \bar{o} \mathrm{n}$ b ĕkāmkām is smid. Men heeft onder de Papoea's geen verdeeling van ambachteu. Ieder werkt voor zich zelven. Maar er zijn er dan toch, die in 't een of ander werk boven de anderen uitmunten.

I a duidt op een bepaalden smid.

7• Volgr. VII. 
4. Mangarpis. Honigzuigertje. Klein, algemeen voorkomend vogeltje.

5. Kam wef. Wef is stuk slaan. Mef is uit zich zelve breken. $\mathrm{K} \overline{\mathrm{a} m}$ wef. Door 't slaan met den hamer, verpletteren.

6. Insĕrēn. Vrije vrouw. Titel van alle vrouwen, die van vrije geboorte zijn.

7. Or. Roepen. Een smid heeft voor zijn werk verschillende helpers noodig. Den eenen dag helpt deze hem, den anderen dag een andere. Zoodat hij eerst zijne helpers bij elkaar moet roepen voor hij aan 't werk kan gaan.

8. As šr. Volgen. Bedoeld wordt, dat hij zijne vrouw niet na afloop van 't werk terstond nar huis volgde. De gewoonte van hen, die smidswerk verricht hebben, is na afloop van den arbeid te gaan baden in een beekje, liever dan in de zee.

9. Mgir. Te voorschijn komen uit het bosch.

10. De hier genoemde gereedschappen werden door de vrouw in een zak gestopt. Dit zou dan als bewijs moeten dienen, dat die tweede vrouw den man had bedrogen, en die zak met gereedschappen op de buik gebonden had.

11. Fuāk sārmā. Sārmā spelen. Een soort voetbal. De bal is van rotan gevlochten.

12. Māns ĕrēn. Titel van mannen, in vrijheid geboren.

13. Karapèsa. Stoel. Al wat tot zitplaats dient, heet men karapēsa.

14. Māmbadir. Mam, zien. Māmbadir, nauwkeurig zien. Overigens wordt badir in de beteekenis gebruikt van zich verraden, of ook z. a. in kofein badir, aanzeggen, oververtellen.

15. Rumbri bāb. De Papoesche woningen zijn op palen gebouwd. Het gedeelte onder het huis, dus tusschen de palen is de rum bāb of rum wabni.

\section{Indawāwōrki ma Binkakuri.}

Bin suru, su snōsna Indawāwōrki ma Binkakuri, su serf roiam. Indawāwōrki i d'un ingumbu ( $\left.{ }^{1}\right)$ be rum, Binkākuri i d'un roiām, $\left({ }^{2}\right)$ krāf bĕba.

Indawāwōrki, i msor, i bur, ma i barĕk ro nejan bori. Kapō $\left({ }^{3}\right)$ s'ōpĕr ( $\left.{ }^{4}\right)$ ro krāf bjeda.

Binkakuri i mbrein nejān ōrnĕ, i mām kāpo, i pas na. I pas kapo ro Indawāwōrki andendi bjeda, bin ōrně, i kāndor, ma i d'orĕs, i sankakirare Binkākuri, isōf i mar. Indawawōrki i kēruk 
Binkākuri sus bjena, i d'un be rum, i buk sunsna, faro Binkākuri nei bjedi, snōriso Imawai ma Indawawarki, i bur Imawai i kun susna, sunsna, su kaněs, imnis snunkaku. Imawei i kāndor, i san susna.

Imawai, i d'or Imběbai, Indawawōrki nei bjedi, i kōfein: "Wairus $\left({ }^{5}\right)$ jeda $i$ sapi, wa serf $i$ ". Ma Binběbai i sābu $\left({ }^{6}\right)$ fa i serf Imawai wairus bjeda. Ausōnā Imawai, i rir kēru ōso ro for, ma i d'or Imběbai : "Wa mawab $\left(^{7}\right)$ sbambri". Imběbai i know be bo, i mawāb sbari ma Imawai i san kēru běsām ro Imběbai sbari. Kēru, i sapi ro Imběbai suēri, i mar.

Imawai, i d'un Imběbai uk di suru, ma i rir ōso ro rumurndi, wēsě ro rum raundi, ma i famāngor Imběbai kuker sre babo ma sāmfarna ro rwasi ma Imawai i be fa d'orěs Imběbai ro kērwa,

Inda wa wōrki i bur wer be rum, i mām nei bjedi, i d'orĕs wārk ( $\left.{ }^{8}\right)$ kērwa, i famāngor i kwar, i disĕn. Bape i mām kaku, i mām nei bjedi, i mar kwar. Ma i d'or Imawai. Uk ro rum urndi i karĕm. Indawawōrki, i serf ro rum urndi, I d'or wer Imawai, uk ro rum raundi i karĕm. I serf ro rum raundi uk ro rum urndi, i karēm wer. Ānsōna Indawawōrki i mām uk, su karēm, i kōfein : "Imawai i mun nei jedi kwar, rēsĕri i bur". Ma Indawawōrki i jom Imawai.

Rōb, Imawai i d'ènĕf ro mun ōso ro aimando, ma Indawawōrki i d'ènef ro mun wēsĕ. Arwo Imawai i bur wer, ma Indawawōrki i jom weur bjena.

Imawai i rama ro warběki, i d'asuk $\left({ }^{10}\right)$ waria. I mām wōngor, $\left({ }^{9}\right)$ i fukĕn, i d'un i. I kōfein faro wōngor: "Bin ōso, i jom aja, i mum sna jedi; ānsōna i serf, i mum aja kakō. Bin i rama, wa mun i. Wōngor d'ōbo: "Wa kein ro kruri jedi munda". Ma Imawai i sabu kwar, Indawawōrki i rama, ma i d'or wōngor, i d'un i. Wōngor kōfein: "I bje, wa kein ro purari jedi wauerik". Ma wōngor i d'as kukĕr Indawawōrki, bape war i d'ejĕk ro binia fandu, bin, i kōfein: "Napirmō, ja ro". Wōngor kōfein: "Wa mkak awer, nei, j'un knìkirine ani, rariria". War i d'ek söf sbari, bin, i kōfein wer: "Nipirmō, kuikko ja ro. Wōngor d'ōbo: "Wa mkak awer, nei j'un kuîkirine ani, rariria kwar". Ma wōngor i d'as wer, war i d'ek bo binia rwuri, i msar. Ma Imawai i mam ōrně, i disěn, ma i kĕrjair $\left({ }^{12}\right)$ Indawawōrki.

\section{Indawawōrki en Binkākuri.}

Twee vrouwen, wier namen waren Indawawōrki en Binkākuri, zochten schelpen. 
Indawawōrki bracht ing umbu thuis, Binkākuri bracht een schelp, met veel vleesch.

Indawawōrki werd boos; ze ging weg en lag op het voetpad. Paddestoelen botten uit op haar lichaam.

Binkākuri, die op dat pad liep, ziet de paddestoelen, ze trekt ze uit. Als ze de paddestoelen uittrekt van de borst van Indawawōrki, schrikt deze vrouw, ze kitelt Binkākuri, tot ze sterft. Indawawōrki snijdt de borsten van Binkākuri af, en neemt ze mee naar huis. Ze geeft de borsten aan de dochter van Binkākuri, genaamd Imawai en Indawawōrki gaat heen. Imawai roostert de borsten, deze huilen, als een mensch. Imawai werpt van schrik de borsten weg.

Imawai roept Imběbai, het meisje van Indawawōrki, en zegt: "Mijn naald is gevallen, zoek die". En Binběbai daalt neer om de naald van Imawai te zoeken. Nu legt Imawai een steen in het vuur, en ze roept tot Imbĕbai: "Doe je mond open". Imbĕbai kijkt naar boveu, ze doet den mond open en Imawai werpt den heeten steen in den mond van Imběbai. De steen valt in de buik van Imbĕbai, ze sterft.

Imawai neemt twee luizen van Imbĕbai, en ze legt een in het achterhuis, de andere in het voorhuis, en ze versierde Imběbai met een nieuwe sarong en armbanden aan de armen en Imawai liet Imbĕbai aan de deur staan.

Indawawōrki, weer naar huis gaande, ziet hare dochter, in de deur staande, (ze ziet) dat ze zich versierd heeft, (en nu) gaat ze zingen. Mar nauwkeurig ziende, ziet ze dat hare dochter dood is. En ze roept Imawai. De luis uit het achterhuis antwoordt; Indawawörki zoekt in het achterhuis. Ze roept weer Imawai, de luis uit het voorhuis autwoordt. Als ze in het voorhuis zoekt, antwoordt de luis uit het achterhuis. $\mathrm{Nu}$ merkt Indawawōrki, dat de twee luizen antwoord geven en ze zegt: "Imawai heeft mijne dochter gedood, en toen is ze vertrokken". En Indawawōrki achtervolgde Imawai.

Des nachts slaapt Imawai op 't ééne gedeelte van een omgevallen boomstam, en Indawawōrki slaapt op het andere gedeelte. Des morgens gaat Imawai weer weg, en Indawawōrki achtervolgt haar weer.

Imawai komt aan eene rivier, ze zwemt de rivier over. Ze vraagt aan een krokodil, dien ze ziet, haar mee te nemen. Ze zegt tot den krokodil: "Ik word door eene vrouw achtervolgd die mijne moeder gedood heeft, nu zoekt ze mij ook te dooden. Dood die vrouw als ze komt." De krokodil zegt: "Ga maar op mijn rug zitten !" En toen Imawai afgestegen was, komt Indawawōrki en vragt den krokodil, 
haar mee te nemen. De krokodil zegt: "'t Is goed, zit maar op mijn staart". En de krokodil zwemt met Indawawōrki, maar toen het water tot het midden der vrouw gekomen was, zegt de vrouw: "Neef, ik ga verloren!" De krokodil zegt: "Vrees niet, 't meisje, dat ik zooeven meênam, ging 't evenzoo!" Als het weer tot den moud is, zegt de vrouw weer: "Neef, zoo dadelijk ben ik verloren!" De krokodil zegt: "Wees niet bang, het meisje, dat ik zooeven bracht, ging "t ook zoo!" En de krokodil zwemt weer verder, het water stijgt boven 't hoofd der vrouw, en ze verdrinkt. En Imawai dit ziende, zingt en jouwt Indawawōrki uit.

Aant. 1. Ingumbu. Krabbe, die in verlaten schelpen huist. Wordt de schelp te eng, dan verhuist de ingumbu naar eeu grootere. Men kan die diertjes met elkander zien vechten, om een leege schelp, tot het eindelijk één gelukt haar te veroveren. Men zoekt deze krabben wel voor aas om te visschen, maar ze dienen niet tot voedsel voor visschen.

2. Roi am, krāf bĕba. Roi am zijn echte schelpdieren, die wel tot voedsel dienen.

3. K a p ō. Paddestoelen. Eetbare soort.

4. $\bar{O}$ pĕr. Hier vertaald door uitbotten. 't Woord beteekent eigenlijk springen.

5. W alrus. Naald. De gewone naainaald heet ret. Hier wordt bedoeld een naald van de groote eener stop- of paknaald, waarmee de pandanusbladeren tot matten aanééngehecht worden.

6. Sabu. Afdalen. Door de groote reten, die de Papoea's laten in de vloeren hunner wonigen, valt nog al eens het een en ander onder het huis. Binbĕbai moest dus om die naald te zoeken, zich onder de woning begeven.

7. Mawābs sari. Den mond openen. Mawāb alleen is voldoende voor openen van den mond. Bas is openen in 't algemeen.

8. Orĕs wārk. Samengesteld uit ōrĕs en wārk. Ōrĕs, staan en $w \bar{a} \mathbf{r k}$, beletten. Door haar staan, belemmerde, belette ze 't ingaan in de deur.

9. W ōngor. Krokodil. Niet overal is er eene vijandige verhouding tusschen krokodil en mensch. Op Meos War b.v. wilde men niet, dat een mijner roeiers schoot op een krokodil,' want zoo ver men zich herinneren kon, was er nooit iemand van Meos War door een krokodil gebeten. Begou men nu die goede verstandhouding te verbreken, dan zou daarvan 't gevolg zijn eene altijddurende veete tusschen krokodillen en menschen. 
Aan de Humboldts-Baai werd me gezegd, dat wanneer aan de Karwari de figuren opgehangen werden, die kasuarissen en krokodillen voorstellen, men dan die houten kasuarissen en krokodillen vraagt hunnen makkers in bosch en water te gebieden, menschen, die iets verkeerds gedaan hadden te trappen en te bijten.

10. Kĕrjair. Uitjouwen. Ook kōrjar.

\section{Bumambraundi.}

Imbĕkĕpu suru, su na (') rumgun kĕpuri, snōriso Bumambraundi. S'ap i Bumāmbraundi, $\left({ }^{2}\right)$ snar i fuāk bumam māngěnēm. Isna $\left({ }^{3}\right)$ sōf māndira i fnāk bumām munda. Kĕpuri bjedi, i msor, i kōfein: "Rumgun wēsĕ, si serf in, bape au w'èněf, wa fnāk bumam, w'an, w'èněf, wa fnāk bumām wer"/.

Kĕpuri, i fnap pōkēm, $\left(^{4}\right)$ i kapu ro sajēr Bumambraundi pōkēm bjeda. Bumambraundi, i d'ek fa i d'an, i kōfein : "Bumi, pōkēm i snarēm be kapu. Kĕpuri, i kōfein : "Alboi, snar au, wa fnāk bumam māngĕnēm.

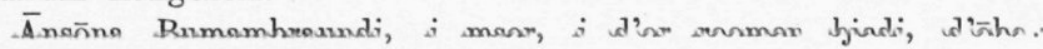
"Ku serf in !" Su serf in, su mām saroj. Bumambraundi i so sarōj kuker jāfēn bjeda, bape saroj i sjob wa kuker Bumambraundi ma women bjedi, ma i d'orrĕn su kuker wa seda.

Su kein ro sarōj snēri, su biser. Su sma for ba, su frōběkun $\left(^{5}\right)$ kuker ādi. $\left({ }^{6}\right)$ Su sma for, su kēruk sarōj kènia, ma si fnap ken. Sarōj i mar.

I mar, rìsĕn, i san sarōj bĕmar ro bo be sōp, ma Bumambraundi i kōfein : "Sarōj, i marke, ku j'ek ma ko sabu munda. Su fnēwerr $\left({ }^{7}\right)$ su knasna, su mnāf rìsĕn, ma su kōfein : "I mar baboi ma su kna sarōj snēri, ma su sasiar.

Su borĕs, su mām warběki. Bumambraun i masi. I masi, i mām āngra běkes, i da; i kin, i mām, si kēruk i bābo, d'ōbo: "Snunkaku i masi ro warrwuri, piapĕr rwuri kuker āngra!"

I mām angra bĕkes sumundi, $\left({ }^{8}\right)$ i kin i, i mām snumburaim i piarkēpěn āngra. I d'un snumburaim, snumburaim i kwaim, d'ōbo : "Bin i masi, ja ra, ja mām i !" I kōfein faro womĕn : "Wa kein ro wa, ja mām suunkaku i masi ro warrwuri.

I mbrein- i mām diāf. Ro diaf, i mām rum kapirare. I d'ek rumia, bape rum i bro. I waf, i mam ingubor ōso, i masi bābo, i d'āpěn jās. $\left({ }^{9}\right)$ Bin i rama. Bin, i mām Bumambraundi, i fukĕn i : "Wa serf rosei ?" Bumambraundi i kōfein : "Wa jeda i sia ro warweri kuker womĕn jedi. Nu biser, riani ja serf rōbĕan, bjēfke!" 
Bin, i kōfein : "I bje, w'un bjēf wauěrik, bape wa bur fasau, snaro kĕpuri jedi i rama knìko, ma insar i nai mānoin, $\left({ }^{10}\right)$ ja mkah, nēri i mun au.

Bumambraundi, i bur. I bur kwar, knìko insar kukĕr nāf bjedi (nāf, i kākō bĕmanoin), su rama. Su j'un sunukaku (' $\left.{ }^{1}\right)$ kukĕr rumun. Insar, i buk rumun faro nei, ma māngundi i kun snunkāku.

Nāf, i snarĕm Bumambraundi māmās (12) bjeda, i d'ob ma i d'ark awēk. Insar i kōfein: "Mundiri i d'ek rum, nāf i d'ark awēk ?" Bape bin i kōfein : "Ja masi ma ja rmìmĕn $\left({ }^{13}\right)$ rwuri, nāf, i snarĕm mani, rjani i d'ark awēk.

Mandira, $\left({ }^{14}\right)$ insar kukĕr nāf, su bur wer, Bumambraundi i rama kukĕr wa. Si biaun bjēf ma roběan nabor, kníko wa i msar, ma bin i so.

Arwo, insar kukĕr nāf, su rama wer, nāf i d'ark awēk wer. Insar i d'or nei kĕpuri : "Mundiri i rama mobinè, nāf, i d'ark awēk". Bape ōso i karemba. Insar i d'ek rum, i mam rum i bro. Ānsōna, i mām weur ro kajĕn, i kōfein : "Snun ōso i d'un i!"

I d'ek wa bjeda, ma i wan nāf bjedi, i barēk ro wa raundi.

I jom Bumambraundi sko, $\left({ }^{15}\right)$ Bumambraundi, si pōkba. Insar wa bjeda fanam rape, ma si mnaf, i disĕn :

"Insarodi wa sasiki $\left({ }^{16}\right)$ wa jar jar $\left({ }^{17}\right)$ pon,

Bumambraundi wa jar jar pur!"

Bumambraundi, i kōfein : Nēri ko frur rosei, bin ōrnĕ i pākrìk - mĕnōf, iko, na kiur i ba". Bin i kōfein: "Ko so i kukĕr manposswabōr, (18) i mar. Insar wai bjeda, i fanām kāku, kēpuri bjedi i d'orěs ro wa, ma i so kāki $\left({ }^{19}\right)$ insar kukĕr māmposswabōr; insar i sāpi, i mar. Ma wa, i da kukĕr nāf munda.

Bumambraundi kĕpuri, i waf rumgun kĕpuri munda. Rās rās, i d'asarin ro rumbrawer, i mām Bumambraundi, i ramake.

Rās ōso, si kōfein : "Ko mām wa ōso, ōrnĕ Bumambraundi wa bjeda. Wa fanām knīk, si kōfein : "Roba, snunkaku di kiōr, rjāni Bumambraundi d'iriaba. Bape si mām kāku, si k̄ōfein : "Roba, Bnmambraund'iria, i d'un bin".

Ma kĕpuri, i marisein nāba, Bumambraundi kukĕr swari, su j'ek rum bjeda.

\section{Bumambraundi.}

Twee grootouders hadden een kleinzoon, wiens naam was Bumambraundi. Ze noemden hem Bumambraundi, omdat hij zoo veel met den tol (bumām) speelde. Van den morgen tot den avond, speelde 
hij maar met den tol. Zijne grootmoeder werd boos, en zeide: "Andere jongens zoeken visch, maar gij slaapt, gij speelt met den tol, ge eet, ge slaapt, ge speelt weer met den tol."

Zijne grootmoeder kookte gierst en toen deed ze hare behoefte in den houten bak, waarin de gierst van Bumambraundi was. Als Bumambraundi (in huis) geklommen was om te eten, zeide hij: "Grootmoeder, de gierst stinkt naar st..." Zijne grootmoeder zeide : "Dat is, omdat ge te veel met den tol speelt."

$\mathrm{Nu}$ werd Bumambraundi boos hij roept ziju slaaf, en zegt: "We gaan visschen!" Als ze aan 't visschen zijn, zien ze een walvisch. Bumambraundi werpt den walvisch met zijn harpoen, maar de walvisch trok de prauw met Bumambraundi en zijn slaaf naar zich toe, en hij slikte hen beiden in met hunne prauw.

Terwijl beiden in de buik van den walvisch zaten, kregen ze honger. Ze hadden geen vuur. Ze maakten echter vuur, door de uitleggers der prauw tegen elkaar te wrijven. Toen ze vuur gekregen hadden, sneden ze den lever uit van den walvisch, en ze kookten den lever. De walvisch stierf.

De branding wierp den doodeu walvisch op en neer, en Bumambraundi zeide: "Zou de walvisch dood zijn wij stijgen en we dalen maar." Ze legden hunne ooren te luisteren en hooren de brauding. $\mathrm{Nu}$ zeggen ze: "Welzeker is hij dood!" en ze sneden den buik van den walvisch open, en ze gingen er uit.

Ze roeien verder en worden een rivier gewaar. Bumambraundi gaat baden. Als hij baadt, ziet hij een doorgesneden citroeu drijven. Hij grijpt die en ziet, dat de citroen pas doorgesneden is. Hij zegt: "Iemand baadt aan den bovenloop van de rivier, die zich het hoofd met citroen gereinigd heeft!"

Als hij het andere gedeelte van den doorgesneden citroen ziet, grijpt hij dit ook en ziet een haar om den citroen heen gedraaid. Hij neemt dat haar en als hij ziet, dat 't een lang haar is, zegt hij : "Er is eene vrouw aau 't baden, ik ga haar zien!" Hij zegt tot den slaaf: "Blijf in de prauw, ik ga zien, wie er baadt hooger op aan de rivier."

Hij loopt, en ziet een tuin. In den tuin ziet hij een klein huis. Hij bestijgt dat huis, maar het huis is leeg. Hij wacht. En nu ziet hij eene maagd, die pas gebaad heeft, zich warmen in de zonneschijn. De vrouw komt. Als die vrouw Bumambraundi ziet, vraagt ze hem: "wat zoekt gij?" Bumambraundi zegt: "Mijne prauw is aan den mond der rivier met mijn slaaf. We hebben honger, daarom zoek ik eten, is er pisang?" 
De vrouw zegt: "Goed, neem maar pisang, maar ga spoedig heen, want mijne Grootmoeder komt zoo dadelijk, en de oude vrouw heeft eeen weerwolf, ik ben bang, dat ze u dooden zal."

Bumambraundi ging heen. Toen hij vertrokken was, komt spoedig daarop de oude vrouw met haren hond (de hond was ook een weerwolf). Ze brachten een mensch mee met een varken. De oude vrouw geeft het varken aan het meisje en zelf roostert ze den mensch.

De hond ruikt de reuk van Bumambrauudi, hij blaft en hij bijt deu ladder. De oude vrouw zegt: "Wie is er in huis geklommen, de hond bijt den ladder?" Maar de vrouw zegt: "Ik heb mij gebaad en miju hoofd met olie gesmeerd, de hond heeft de olie geroken, daarom bijt hij in den ladder" .

's Avonds gaan de oude vrouw en haar hond weer weg, Bumambraundi komt met de prauw. Ze laden pisang en zeer veel eten, bijna zonk de prauw, en de vrouw volgde.

's Morgens komen de oude vrouw en de hond weer, de hond bijt weer in den ladder. De oude vrouw roept hare kleindochter toe: "Wie is hier gekomen, de hond bijt in den ladder?" Maar niet één geeft antwoord. De oude vrouw klimt in huis, ze ziet het huis leeg. $\mathrm{Nu}$, ziet zij de voetsporen in het zand en ze ze zegt: "Een man heeft haar weggehaald!"

Zij klimt in hare prauw, en ze beveelt haren hond te gaan liggen in het voorste gedeelte der prauw.

Zij achtervolgde Bumambraundi, en de zijnen. Bumambraundi en de zijnen konden niet langer. De prauw van de oude vrouw is reeds dichtbij, en ze hooreu haar zingen:

"De prauw van de oude vrouw zwemt 't eerst,

De prauw van Bumambraundi zwemt achter!"

Bumambraundi zegt: "Wat zullen we doen, de vrouw is onkwetsbaar, speren, pijlen treffen haar niet." De vrouw zegt: "Als we haar werpen met de baard van de māmpōs, sterft ze." De prauw der oude vrouw, was zeer dichtbij, hare kleindochter gaat in de prauw staan, en werpt de oude vrouw met de baard van de māmpōs; de oude vrouw valt dood neer. En de prauw drijft alleen met den hond.

De grootmoeder van Bumambraundi wacht steeds haren kleinzoon. Elken dag zit ze gehurkt in het aan zee gelegen deel van het huis, ze kijkt of Bumambraundi komt.

Op zekeren dag wordt geroepen: "We zien eene prauw; dat is de prauw van Bumambraundi." Toen de prauw een weinig dichtbij 
was, zeggen ze: "Neen, drie menschen, dat kan de prauw van Bumambraundi niet zijn." Maar als ze goed zien, zeggen ze: "Neen 't is Bumambraundi wel, hij brengt eene vrouw mêe".

En de grootmoeder was zeer blij, toen Bumambraundi met zijue vrouw te zamen haar huis binnenklommen.

Aant. 1. Na. Hebben. Dit na hoort men afwisselend met $\mathrm{nai}$ in dezelfde beteekenis.

2. Bumambraundi. Gouden tol. Bumam, tol, braun of brawĕn, goud. De bumam is een soort priktol, die de Papoesche knapen zelve snijden en met touw opzetten.

3. Isna. Het is licht. Wordt gebruikt voor morgenstond.

4. Pōkĕm. Gierst. Deze gierst wordt ook op N.-G. gewonnen op de bergen. 't Is een geliefd voedsel.

5. Frōbĕkun. Vuur krijgen door 't wrijven van twee houten. Bekende methode bij wilde volkstammen.

6. Adi. Uitlegger aan de prauw. Wordt gemaakt van zeer licht hout.

7. Fnēwĕr. Neigen, schuin houden. Ook van de zon bij 't ondergaan. Fnēwĕr knasi, het oor neigen om te luisteren.

8. Sumindi. Waarschijnlijk van imnis, gelijk, eveneens. Sumindi, die er bij behoort, de gelijke er van.

9. Āpĕn jās. Zich warmen in de zonneschijn; āpĕn for, zich warmen bij 't vuur.

10. Mānoin. Weerwolf. De mān oin speelt bij de Papoea's denzelfden rol, dien de weerwolf vervulde in 't bijgeloof onzer voorvaderen. 't Geloof aan zoo'n weerwolf is over den ganschen Archipel verspreid. $\mathrm{Na}$ zousondergang verwijdert geen Papoe zich alleen op eenigen afstand van het strand. Men zegt, dat enkele personen behept zijn met de macht anderen te dooden door bovennatuurlijke middelen. Wordt door 't wichelen iemand aangewezen als bezittende een mānoin, dan moet hij volgens oude zeden worden gedood.

Later geeft een ander sprookje ons meer gelegenheid den aard van dit bijgeloof te leeren kennen.

11. Snunkaku. Snun is man, kaku, echt. 't Woord beteekent echter niet uitsluitend mannen. 't Is veel meer: iemand, mensch in 't algemeen.

't Wordt ook gebruikt om aan te duiden dat 't kieken reeds in 't ei gevormd is.

12. Māmās. Vuil. De hond rook B's vuil. Algemeen is deze 
wijze van spreken in betrekking tot het ruiken van iemands bijzondere uitwaseming. De Papoea's zelve hebben soms een zoo fijn reukorgaan, dat ze iemands bijzondere geur kunnen onderkennen.

13. Rmìměn. 't Hoofd smeren of zalven met olie.

14. Mandira. Avond. De tijd, dat de mānoins hunne prooi zoeken te bemachtigen.

15. Sko. Zij met hun drieën. Su, zij met hun tweeën.

16. Sasiki. Dit woord ken ik niet.

17. Jar. Hier overdr. gebruikt. 't Is het zwemmen van visschen.

18. Mām pōs. Is een visch, die een soort snor ( $\mathrm{s}$ wa bor) vertoont. 't Is met deze snor, dat de oude heks alleen te dooden is.

19. So kaki of so kakir. Werpen. Wat dit kāki of kākir beteekent weet ik niet. So is op zich zelve reeds werpen, gooien.

\section{2. ( $\left.{ }^{1}\right)$ Radja Kōrare, $\left({ }^{2}\right)$ radja Djilolo, $\left({ }^{3}\right)$ radja Batjan, radja Karnaki. $\left({ }^{4}\right)$.}

Kapal, i d'ajujĕn ro sorĕn bĕba. Sof $\left({ }^{5}\right)$ bĕba i d'ōrĕn kapal kukĕr kawāsa kaim. Mangangan wer, i kin sof kukĕr kapal, i d'un be sup. Sof, i mērbāk, mangangan, i pōkba, ma sof kukĕr kapal i sapi ro sup. Sof i pōkĕm, kāwāsa ro kapal, si sasiar. Si mbrein be radja ro sup orwa, sup Rumi. $\left({ }^{6}\right)$

Ma radja, i ker samarāka, $\left({ }^{7}\right)$ i ba kāku, ma kāwāsa, si frur kērwa ro samarāka ma s'an ro dōri. Snun ōso, i bur i d'as be Korore, i serf war.

1 d'inĕm war, bin war ro nanggi, si masi, si rir sānsun sena kukĕr waprerna ro sup. Snun ani, i d'un bin běba sānsun kukĕr waprerna. Biu, si masi ibro, s'ek be nanngi wer, bape ōso i.d'awaw.

Ansōna snun ani i badir $\left({ }^{8}\right)$ i, d'ōbo i d'un sānsun, ma waprer bjena; d'ōbo, i buk i.

Snuu ma bin, su ra be insar, i keiu ro sup ōrnĕ. Su kein knīk, insar i kōfein: "Mu kein mob ini munda, ma mu serf in mara aja ba."

Bin, i pas snumburaim ma i frur sarfer, i buk faro snun, i kōfein : "Sārfer îs ōrně, wa serf in". Warpur wer i pas snumburaim ōso wer, ma i frur djara. $\left({ }^{9}\right)$

Snun, i borĕs, i pōs in, i sma in si bor, imbĕrnōs, insum, in kam, wa i msar. I mbrein be rum, i kōfein faro bin: "In i sia, wa i msar".

Iriria ras kiōr. Ras bĕkiōr, bin, i kein ro rum, i mām be bo ; 
i mām waprer posom, snun i jōkēf ro os. I swarepĕn. nēri i bur wer, bape i bur fasauba.

Rās ōso, i frur robĕan faro rumgun fiāk bjesi ma faro swari, i kōfein faro rumgunsi : "Roběan faro mgokmasri i sia - ja bur!" Ma bin i d'un waprerna i bur be bo. Rumgun, si waf sikmasri ba, s'an roběan ibro.

Bĕpōn, i d'an ben bjeda i bro, i bur, i kein ro kēru běba ro wōndi; bĕsuru i d'an ben bjeda ibro, i bur be wōndi, i kein ro aiknam; rumgun běkior i d'an bjeda ibro, i mbrein be wōndi, i kein ro kēru ani pembri; ma běfiāk, i mbrein fauirbaim, i kein ro medja bori.

Běba, i radja Kōrare ( $\left.{ }^{10}\right)$, běsuru radja Djilolo, bĕkiōr radja Batjan, běfiāk radja Karnaki.

$$
\begin{aligned}
& \text { 32. De koningen van Tidore, Djilolo, } \\
& \text { Batjan, en Ternate. }
\end{aligned}
$$

Een schip zeilde in den grooten oceaan. Een groote s o of slikte het schip in met al het volk. Een arend greep weer de so of met het schip, en bracht het naar het land. De s o of was zwaar, de arend kon ze niet langer houden, en de s o of viel met het schip op den grond. De so of rotte, het volk uit het schip ging er uit. Ze gingen naar den koning van het land, het land Rumi.

De koning had een watermeloen geplaut, die zeer groot was, en het volk maakte een deur in die watermeloen en zij aten er zich in. Een der mannen zwom naar Tidore, om water te zoeken.

Terwijl hij water drinkt, leggen acht hemclvrouwen, die daar baadden, hare kleederen en vleugels ter aarde. Die man neemt de kleederen en vleugels weg van de oudste (grootste) vrouw. Toen de hemelvrouwen klaar waren met baden, stegen ze weer ten hemel, maar één kon niet (was gefopt).

$\mathrm{Nu}$ maakt de man zich bekend, zeggende, dat hij hare kleederen en hare vleugels weggenomen heeft; hij zegt, met haar te willen trouwen.

De man en vrouw gaan beiden naar de oude vrouw, die in dat land woonde. Toen zij daar eeu poos waren, zeide de oude vrouw: "Gij zit hier maar, en gij gaat niet voor mij visschen."

De vrouw trekt een haar uit en maakt een vischlijn, zij geeft die aan den man, zeggende: "Dat is een vischlijn, ga visschen!" Later weer trok zij weer een hoofdhas uit en maakte een net.

De man gaat roeien en visschen, en hij vangt zeer veel visch, 
imbĕrnōs, insum, allerlei soort visch, zoodat de prauw tot zinkenstoe vol was. Hij gaat naar huis, en zegt tot de vrouw : "De prauw is tot zinkens toe vol met visch."

Zoo ging het drie dagen. Den derden dag kijkt de vrouw, die thuis zit, naar boven en ziet den top van den vleugel, die de man had verstoken tusschen de atap. Ze dacht er over weg te gaan maar ze ging nog zoo gauw niet.

Op zekeren dag zegt ze tot de jongens, nadat zij het eten voor hare vier kinderen en voor haren man heeft gereed gemaakt: "Het eten voor uw vader is daar - ik ga heen!" En de vrouw neemt de vleugels en stijgt naar boven. De jongens wachten niet op hunnen vader, zij eten het eten op.

Als de eerste zijn bord' heeft leeg gegeten, staat hij op en gaat zitten op een grooten steen buiten, de tweede gaat naar buiten als zijn bord is leeg gegeten en gaat zitten in een boom; de derde eet zijn bord leeg en gaat zitten op het kantje van dien bewusten steen; de vierde, die nog niet goed loopen kan, gat boven op de tafel zitten.

De oudste, dat is de sultar van Tidore, de tweede sultan van Djilolo, de derde sultan van Batjan, de vierde sultan van Ternate.

A ant. 1. Dit verhaal bevat de bovennatuurlijke geboorte der Moluksche Vorsten.

Reeds Valentijn vermeldt, deel 1 blz. 279, eene legende omtrent de wording der vorsten van Ternate, Tidore en Batjan :

„De koningen van Ternate, Tidore en Batjan zeggen, dat zij van denzelfden draak, doch ieder uit een bijzonder ei, gesproten zijn, om welke redenen de koning van Batjan een draak boven op zijn paleis heeft uitgesneden staan. Anderen, dit wat verder ophalende, zeggen, dat de moluksche eilanden van ouds door een vorst, Bigara of Bikoe Cigara genaamd, bestuurd zijn en geven verder dit navolgende verdichtsel als eene zuivere waarheid op, dat deze vorst op zekeren tijd uit varen gegaan en met zijn gilala (een zeker snelzeilend en tegelijk licht roeivaartuig) omtrent Batjan gekomen zijnde, eenige bamboezen of indiaansch riet tusschen de klippen gewaar werd, 'twelk hij gelastte af te kappen, maar dit was zoo ras niet begonnen, of men vernam bịj den eersten kap, dien men daar in deed, dat er eenig bloed uit kwam. Dit ontstelde dezen bijgeloovigen zeer sterk, maar nog veel meer, dat hịj aan den wortel van dien bamboes-stoel (want zoo groeien zijj bijeen) vier eieren vond, die zeer veel naar slangeneieren geleken. Terwijl hij nu bezig was met deze eieren te beschouwen, hoorde hij een stem, als uit het riet voortkomende, tot hem zeggen: 
„Gij moet deze vier eieren wel gadeslaan en wel bewaren, alzoo uit dezelve vier vorstelijke personen staan geboren te worden." De vorst, hierdoor opgetogen, nam die eieren mede naar zijn paleis en vernam niet lang daarna, dat daaruit drie mannen en eene vrouw te voorschijn kwamen, van welke éen de stamvorst der koningen van Batjan, éen de voorvader der boetonsche koningen en éen de stamhouder van een der vorsten in de papoesche eilanden was, gelijk dan die vrouw ook een zeer machtig vorst van Loloda, op 't groot land van Halmahera, getrouwd geweest is. Ter gedachtenis van dit voornoemd voorval eeren veel van deze volken niet alleen dezen Bakoe Cigara, maar zelfs ook nog die rotsen, tusschen welke de eieren gevonden zijn. Waarbij men nog voegt, dat uit het ei des eersten konings van Batjan dertien heidensche vorsten van Ternate, na elkander gesproten zijn, tot dat een sultan van Tidore, Bonga genaamd, opdaagde, die den alcoran, of 't moorsch geloof aannam; doch wie deze koning geweest zij, blijkt mij nergens, zoodat het maar een opgeven van 't moedig Batjansch koningje is, dat zich uit dezen hoofde ook beroemt de oudste van de moluksche koningen te zịn, ten bewijze van dien nog de klippen en de plaats omtrent zijn land, waar dit voorviel, vertoonende.

Dit is dan eon yerhaal, waaruit men klaar ziet, dat het opgeven van den voornoemden oorsprong van deze drie koningen van denzelfden draak, maar uit drie bijzondere eieren, met zeer weinig verandering, uit een dergelijk verhaal der ouden getrokken is."

2. Kōrare. Het Nufoorsch verandert regelmatig de $t$ uit andere talen en dialecten in k. En dikwijls de d in r. Kōrare is ontstaan uit den ouden naam van Tidore, Todor. Ook de verandering van $o$ in $\mathrm{a}$ is niet vreemd. 1

3. Djilolo. Vroeger rijk van dien naam op Halmaheira.

4. Karnaki. De ouder 2 genoemde veraudering van $t$ in $\mathrm{k}$ geeft ook hier de wijze aan, warop dit woord van Ternate is afgeleid.

5. Sof. Een visch.

6. Sup Rumi. Het land Rumi. Dr. Adriani, die in een ToRadjasch verhaal het land $\mathrm{Runi}$ vermeld vond, schreef mij, als zijne meening, dat met dit Rumi bedoeld zou ziju het onbekende land, en waarschijnlijk terug te brengen zou zijn tot het Byzantijnche rijk, dat als deel van het keizerrijk Rome (Rumi), door de Arabieren als het werkelijke rijk van Rome beschouwd werd.

7. Sāmarāka, Watermeloen. De bekende sĕmangka of samangka van Java en elders.

8. Badir. ${ }^{2}$ Een hoogst enkele maal komt dit woord op zichzelf staande voor, doorgaans in samenstelling met andere werkwoorden. 't

1 Zie Nuf. Spraakk. Hoofdst. XIV.

2 Zie Nuf. Spraakk. Blz. 10. 
Heeft dan ook, z. a. in dezen zin, de bet. van vertoonen, bekend maken. 9. Dja ra (djala Mal.) Net.

10. De gebieders van Ternate en Tidore hebben immer in strijd om dẻn voorrang verkeerd. Valentijn $1^{\mathrm{e}}$ deel vermeldt telkens deze oorlogen, waarin de Compagnie zich ook niet vreemd hield. Geen wonder, dat onder de Papoea`s, als goede onderdanen van Tidore, een verhaal ontstond, waaruit bleek, dat Tidore machtiger was dan Ternate.

33. Radja Djilolo, Batjan, Kārnaki, Kōrare.

Bin nanggi samfur, si masi ro Kōrare. Bepon Kōrare, rirwor munda. Ma insar ōser munda bĕdjadi ro rirwor.

Kapal Wolanda, i ro. Tuwan ōser, i bur.

Bin nanggi, si masi, si rir sānsun sena ro insar rum bjeda, ma si pas waprerna, na fnak (') sānsun.

Tuwan ani i mbrein ōrwa, i mam bin nauggi, si masi, i rmomĕn si, ma i d'awěs kukĕr insar, i d'ardu waprerna. Iusar i kōfein : "Wa marisein mundiri ?" Sungubur, i kōfein : "Bĕknìk!" Ma insar, i jōkĕf běknîk waprerna.

Bin nanggi, si masi pōsa, si marisein s'ek be bo. Siw, si fes waprer sena; ōso, i serf, i sma ba. Siw s'ek be bo, ōso i d'awaw. Sungubor ani, i kin bin nanggi ro rwasi, i d'un be rum bjeda ma i buk i.

Bin i sma rumgun. Rumgun ōrnĕ, i ba knīk, bin i sma rumgun wer.

Ras ōso, snun i mbrein, i pōs in.

Bin, i kein, i kĕpur $\left({ }^{2}\right)$ rumgun; i mām be bo, i mām waprerna, snun, i jōkĕf ro ōs. Bin, i d'orĕs bĕri, i fes waprerna, ma i d'ek be nanggi.

Rumgun, i kanĕs naba. Kamari, i d'ek rum, i mām bin mob bjeda, i mām bin maroba. Snun i mām ro ōs, waprer su sia ba. Suun, i swarepĕn bin, i d'ek be nanggi, ma i marisein, i serf i örwa; bape rariso?

I kein ma i kaněs, mangangan, i rama, i fuken i: "Wa kaněs kukĕr rosei ?" Ma suun i faja ro bin, i bor bur i.

Mangangan i farkor i d'ōbo: i d'or man, si kam; nāri ōso, i pōk i d'un i be nanggi.

Suun i fan man, ma man kangramu - mangangan, mansirijew, mangaras, mansowi, sjaran - si rama. Mangarpis kakō. Man běba, si mām mangarpis, si jau i, s'ōbo; i d'an awer, i pok i d'un snun ani be bo ba. Snun i kōfein: "Man kapirare, i d'an wauerik". 
Mangangan i kōfein: "Wa kein ro sasuri jedi, nēri j’un au be bo !" Bape mangangan i pōkba, mansirijew, i pōkba, ōso, i pōkba.

Mangarpis i d'an kwar, i kōfein faro snun: i kein ro kruri bjedi wauĕrik! Snun, i mkak, suar man i kapirare mangĕnēm, bape mangarpis, i kōfein : "Wa mkak awer!" ma i fārkor snun ani, i kein rariso."

Ma snun, i kein ro mangarpis kruri - djadi $\left({ }^{3}\right)$ ! Ma mangarpis riōb be sōp ma i d'ek awawēn be bo. Man běba s'ek be bo bĕri, rjani si mor fasau, ma mangarpis i d'un snun be uanggi.

Mangarpis i d'un snun ani be bo, i rama ro sāmpāk be mēnu nanggi. Rum i sia ro sāmpāk fandu. Bĕnai ro rum, suōriso Sada. Sada, i fukĕn faro i, i serf rosei. Ma snun ani, i faja ro bin, i hor bur i. Sada, i fārkor snun, i kōfein ; "W'āp bin wēsě awer, w'āp sāsar, nēri wa sma sāsar $\left({ }^{4}\right)$, ma bin kām, si muis. Rjani, ja wau rangamak suru. Wa mām bin, rangamāk, su pof radasu bjedi, bin ōrnĕ, bin bedi.

$\mathrm{Su}$ rama ro nejan be mēnu nanggi, snun, i mām snun ōso, bĕdjadi amiais kwar, mgasi, snồri jer. Snun, bĕdjadi amiais, ì d'or snun ani, d'ōbo, i bětulung i. Bape snun, i kōfein: "Mangundau!" Wēsě wer, i mām snun bĕdjadi kēru kwar, mgasi, snōri jeer. Wēsĕ wer bĕdjadi āmin kwar, wēse wer panda. S'or i kaim, bape i kōfein: "Mangunmgo-perkara mgobeda! Mgo bĕsasi $\left({ }^{5}\right)$ sāsar ro āmin , pāndake״.

Snun, i rama ro mēnu nanggi, mānsĕrēn ro mēnu, i fukĕn i : "Wa serf rosei ?" Ma i kōfein: "Ja serf bin jedi!" Mansĕrēn, i d'or bin kaim, si kein ro āmbafēn, i kōfein : "Bin mundiri, bin bani ?" Bape snun ani i fasna fasauba, snaro i waf rāngamāk, Sada, i kōfeinbadir kwar.

Māusĕrēn, i fukĕn wer: "Wa fasna bin fasau ?" Ma snun, i mnāf, rangamāk suru, su rōb ro knasi bjeda, ma i mām, su pōf ro radasi ro bin, i kein ro posom, ma snun, i kōfein : "Bin ōrwabin jed' iria. Mānsĕrēn, i kōfein : "I bje, w'un i, bape wa frur rosei ja kōfein, j'ew āmin ōrnĕ kukĕr papus $\left(^{6}\right)$ ma kukĕr pōkēm. W'un pōkēm kam be wōndi, wa bur kukĕr bin, bape w'un sāsar papus wēsĕ awer". Ma māusĕrēn ro mēnu nanggi i d'ew amin kukĕr papus ma pōkēm.

Rāngamäk, su kōfein faro snun ōrnĕ : "Nēri-nu fnōk au - wa mam !" Ma rāugamāk, su ra ro amin dōri, ma su serf pōkēm mor nakaim. Pōkēm mor na kraf ro rāngamāk wesi, s'un be wondi. Iriria snun i d'un pōkēm kam be wōndi. 
Ma snun, i nai rum ro nanngi kukĕr bin bjedi. Bin, i sma rumgun wer, bape i bĕumgu i baim, snun i swarepĕn rumgun suru ro sōp, i swar su. I kōfein faro mānsěrēn ro menu naungi, i marisein, i siber be rumgun biesu wer. Mānsěrēn kōfein : "I bje!" Ma i rir awēk sarāk, ma snun kukĕr bin, snēri bĕba, su sabu be sōp.

Si sabu wer ro Kōrare, suari i sma rumgun běfiāk. Rāso i fan si kukĕr robĕan; rumgun bĕba i kein ro aimāudo posom, rumguı běsuru ro aimāndo fandu, rumgun běkiōr i kein ro saprōp fanām snari, rumgun bĕfiāk i kein so snari.

Iriria rumgun rauer, snōri Hasān, i djadi radja Djilolo, snar i ro aimāndo posom, i kwaim ro snari; bĕsuru djadi radja Batjan, fauām knìk; rumgun běkiōr radja Kārnaki fanām wer; ma běfiāk i bor bur snari maroba, i djadi mansĕrēn Kōrare.

\section{De koningen van Djilolo, Batjan, Ternate en Tidore.}

Tien hemelvrouwen baadden op Tidore. Vroeger was Tidore slechts een koraalrif. Eene oude vrouw slechts had op het koraalrif het aanzijn gekregen.

Een Hollandsch schip was vergaan. Een heer was ontkomen.

Als de hemelvrouwen baadden, legden ze hare kleederen in het huis van de oude vrouw en dan trokken ze de vleugels uit, die dan bij de kleederen gelegd werden,

Terwijl die heer daar loopt, ziet hij de hemelvrouwen zich baden en hij kreeg lust tot haar en daarom sprak hij met de oude vrouw, die de vleugels bewaarde. De oude vrouw zegt: "Wie wilt gij?" De jongeling zegt: "De jongste!" En de oude vrouw verborg de vleugels der jongste.

Toen de hemelvrouwen klaar waren met baden, wildeu ze weer naar boven. Negen binden hare vleugels aan; maar één zoekt ze maar vindt ze niet. Negen stijgen naar boven, ééu kan niet. Die bewuste jongeling greep de hemelvrouw bij de hand, hij bracht haar naar huis en hij huwde haar.

De vrouw kreeg een zoon. Toen die jongen een beetje groot was, kreeg de vrouw weer een zoon.

Op zekeren dag ging de man visschen.

Terwijl de vrouw neêrzit, haren zoon in de armen houdend, kijkt ze naar boven, en ziet de vleugels, die de man in de atap verborgen had. De vrouw staat dadelijk op, ze bindt de vleugels vast, en ze stijgt naar den hemel.

$7^{\circ}$ Volgr. VII. 
De jongen huilde zeer. De vader klimt in huis, hij ziet de plaats van zijne vrouw, doch hij ziet zijne vrouw niet. De man kijkt naar de atap, de vleugels zijn er niet. De man denkt, de vrouw is ten hemel gestegen en hij wilde haar daar zoeken; maar hoe?

Terwijl hij weenend neer zit, komt een arend, die hem vraagt: "Waarom huilt ge"? En de man vertelt van de vrouw, die hem verlaten heeft.

De arend onderricht hem, zeggende, dat hij alle vogels roepen moet; een zal hem wel hemelwaarts kunnen brengen.

De man voederde de vogels en een groote menigte vogels, arenden, stormvogels, kakatoes, reigers, duizenden komen. Een honigzuigertje ook. Als de groote vogels het honigzuigertje zien, jagen ze het weg, zeggende, dat het niet mee mag eten, want het kan dien bewusten man toch niet naar boven brengen. De man zegt: "Laat dat kleine vogeltje maar mee eten."

De arend zegt: "Zit maar op mijn hals, dan zal ik u naar boven brengen! "Maar de arend kan niet, de stormvogel kan niet, niet één kan het.

Toen het honigzuigertje had gegeten, zei het tot den man, dat hij op zijn rug moest gaan zitten. De man is bang, omdat de vogel te klein is, maar het honigzuigertje zegt: "Vrees niet" en hij onderwees den man, hoe hij zitten moest.

En de man ging op den rug van het honigzuigertje zitten - 't lukte! En het honigzuigertje vliegt naar beneden en het stijgt langzaam naar boven. De groote vogels waren onmiddellijk naar boven gestegen, daarom waren ze zoo gauw moe en het honigzuigertje bracht den man naar den hemel.

Toen het honigzuigertje dien man naar boven had gebracht, komt deze op den weg naar het hemeldorp. Een huis is er op 't midden van den weg. De eigenaar van het huis heet Sada. Sada vroeg hem, wat hij zoekt. En de man vertelt hem van de vrouw, die hem verlaten heeft. Sada onderwees den man, zeggende: "Neem niet een andere vrouw, indien gij verkeerd noemt, dan krijgt ge straf en alle vrouwen gelijken op elkander. Daarom zal ik twee vliegen zenden. Ziet gij, dat de vliegen zich op de schouders van eene vrouw neerzetten, die vrouw, dat is uwe vrouw."

Toen zij gekomen waren op den weg naar het hemeldorp, ziet de man iemand, die veranderd was in een dor hout, alleen met oogen en neus. De man, die in een dor hout veranderd was, riep tot den bewusten man, zeggende dat hij hem moet helpen. Maar 
de man zegt: "Ge moet 't zelf weten!" Vervolgens zag hij, dat er iemaud een steen geworden was, mét oogen en neus. Een ander weer was een bamboe geworden, een ander weer een geweer. Zij riepen hem allen, maar hij zeide: "Ge moet 't zelve weten - 't is uw eigen zaak! Ge hebt zeker een valschen eed gedaan bij bamboe of geweer!"

Toen de man gekomen was in het hemeldorp, vraagt de heer van het hemeldorp: "Wat zoekt ge?" En hij zeide: "Ik zoek mijne vrouw!" En de heer roept alle vrouwen, zij gaan op een plank zitteu. Hij zegt: "Welke vrouw is de uwe? En die man toonde niet spoedig, want hij wacht op de vliegen, die Sada hem toegezegd heeft.

De heer vraagt weer: "Zoekt ge uwe vrouw niet spoedig?" Toen hoort de man, dat twee vliegen langs zijn oor vliegen, en hij ziet ze zich neerzetten op de schouders der vrouw, die aan het einde zat; en de man zegt: "De vrouw ginds - dat is mijne vrouw". De heer zegt: "t Is goed, neem haar mee, maar doe wat ik zeg, $i k$ vul deze bamboe met allerlei dingen en met gierst. Haalt ge al de gierst er uit, dan vertrekt ge met de vrouw, maar haal niet verkeerdelijk andere dingen er uit." En de heer van het hemeldorp vulde een bamboe met allerlei dingen en met gierst.

De vliegen zeiden tot den man: "Wij zullen u helpen, zie!" En de beide vliegen gingen in de bamboe en zij zochten alle gierstkorrels. De gierstkorrels, die aan de pooten der vliegen kleefden, brachten naar buiten. Zoo haalde de man al de gierst er uit.

En de man kreeg een huis in den hemel met zijne vrouw. De vrouw werd weer zwanger, de man echter denkt aan zijne beide zonen beneden, die hij lief had. Hij zegt tot den heer van het hemeldorp, dat hij naar zijne beide jongens terugkeeren wil. De heer zegt: "'t Is goed!" En hij zette een zilveren ladder en de man met de zwangere vrouw, zij daalden naar beneden.

Toen zij weer op Tidore waren afgedaald, kreeg de moeder den vierden zoon. Op zekeren dag voedt zij hen met voedsel; de oudste zit op de punt van een omgevalleu boomstam, de tweede op het midden van den omgevallen boomstam, de derde zit op den grond bij de moeder, de vierde zit bij de moeder.

Alzoo werd de oudste zoon, wiens naam was Hasan, radja van Djilolo, omdat hij op het uiteinde van den boomstam zat, ver van de moeder; de tweede werd radja van Batjan, een weinig dichter; de derde werd Radja van Ternate, weer een weinig dichter; en de 
vierde, die zijne moeder niet verlaten had, werd heer van Tidore.

A ant. 1. Fnōk. Dit woord beteekent helpen, elkander bijstaan. Ook, z. a. in dezen zin, iets toevoegen.

2. Kёpur. In de armen dragen van kindereu.

3. $\mathrm{Djadi}$. Uit het Mal. overgenomen. Wordt meest gebruikt in den zin: 't Gaat, 't gelukt, 't kan wel.

4. Sàsar is verkeerd doen, dwalen. De straf, die men ontvangt wordt ook genoemd: sma sasar (lett. 't verkeerde, de dwaling ontvangen).

5. Sasi. Zweren. Een heel gewone vorm van eedzwering. Op zulke eedzwering, wordt hier gedoeld.

6. Papus. Goederen. Maar ook allerlei dingen, bv. stof, kaboeboeq enz. noemt men papus.

\section{Mĕrāksamana ma Siraimān.}

Māmbĕnaik di suru : Mĕrāksamana ma Siraimān. Mĕrāksamana i mấu, i mām 'bin nanggi samf́ur, si masi. '1 pisàk, 1 mbrem 'be sup fa i serf si. Insar ōso, i fasna ben bĕkaki, bin ani s'ardu sānsun sena. Mĕrāksamana i d'un sānsun ōso, ma insar ani i jōkĕf Mĕrāksamana ro bruwa. Bin siw s'ek be nanggi kwar, Mĕrāksamana, i kin bĕsāmfur. Bin, i marisein i bur; snar ori i d'ek rape, ma i mkak, i mar. Bape Mĕrāksamana i d'un i be rum.

Mĕrāksamana ma Siraimān, su bur, su pōs in, Koranobini( (1) i d'un bin ani.

Mĕrāksamana ma Siraimāñ , su serf, su serf $\left({ }^{2}\right)$, bape su sma ba.

$\mathrm{Su}$ kein ro awafuri. Su kein, su swarepěn mēkēm miun $\left({ }^{3}\right)$ su, bape su mam be bo, su mam snunkaku, i kanes, Mandmuma $\left({ }^{4}\right)$, ōso ro Koranobini kawāsa bjedi.

Snun ōrnĕ i d'inĕm, i d'inĕm, pipa i bro; i d'an, i d'an nabor kaku.

Koranobini i mēwêr $\left({ }^{5}\right)$ i, i japk i, i pai i ro a widom. Mandinuma, i fuken faro Mĕrāksamana su : "Mu serf rosei ?" Su j'ōbo: "Ōso i d'un bin !" Māndinuma kōfeinbadir Koranobini i d'un i. Ma su per i, nari i fnōk su.

Mandinuma i d'inēm masēn i bro, si sma nejan, si ra be Koranobini meos bjeda. Mĕrāksamana su j'ōf $\left({ }^{6}\right)$, Mandinuma i d'ek Koranobini rumia, i mam bin ani, d'ōbo: Swambri i sia, i serf au”. Bin i d'ores, i so Mĕrāksamana.

Si bur wer ro nejān ani. Koranobini i pisak, i mām bin ani ba, 
i jom Mĕrāksamana sko ro nejān ani. Bape s'ek swan sup seda kwar; Mandinumai i d'au war kām, snēri i bro, Koranobini, i msar.

Mĕrāksamaua i d'un bin be rum bjeda wer. Bape bin i d'ek be nanggi wer, snar aumgunsi, si koriajer rumgun bjedi, s'ōbo: si fau snari kawāsa bjedi ( $\left.{ }^{7}\right)$ ba.

Mĕrāksamana i d'akbur be nanggi, fa i serf bin.

Faja wēsĕ, imnis No 33 .

\section{Mĕrāksamana en Siraimān.}

Er waren twee broeders: Mĕrāksamana en Siraimān. Mĕrāksamana droomt, dat hij tien hemelvrouwen zich baden ziet. Hij wordt wakker en gaat naar het bosch om hen te zoeken. Eene oude vrouw toont hem een hoog bord, warin die vrouwen hare kleederen bewaren. Mĕrāksamana haalt een kleed weg en die oude vrouw verberğt Mĕrāksamana in een kist. Negen vrouwen zijn ten hemel gestegen, Mĕrāksamana grijpt de tiende vast. De vrouw wil vertrekken omdat de zon al opgegaan is, en ze vreest te sterven. Maar Mĕrāksamana neemt haar mee naar huis.

Als Mĕrāksamana en Siraimān aan 't visschen zijn komt Koranobini en haalt die vrouw weg.

Mĕrāksamana en Siraimān, ze zoeken, ze zoeken, maar ze vinden haar niet.

Zij gaan onder een boom zitten. Terwijl zij dáár zitten, denken ze, dat de regen op hen valt, maar als ze naar boven kijken, zien ze iemand weenen, n.l. Mandinuma, een van Koranobini's volk.

Die man kan wel een vat leegdrinken en hij eet schrikkelijk veel. Daarom wilde Koranobini hem niet langer hebben en hij bond hem en spijkerde hem in den top van een boom.

Mandinuma vraagt aan Merrāksamana en zijn metgezel: "Wat zoekt gij?" Ze zeggen: "Iemand heeft eene vrouw weggehaald!" Mandinuma verraadt, dat Koranobiui haar heeft weggehaald. En nu maken ze hem los, want hij zal hen helpen.

Mandinuma drinkt de zee leeg en nu ontstaat een weg om naar het eiland van Koranobini te gaan. Mĕrāksamana en zijn metgezel verbergen zich, terwijl Mandinuma in het huis van Koranobini klimt; als hij die vrouw ziet, zegt hij: "Uw man is er, hij zoekt u." De vrouw staat op, zij volgt Mĕrāksamana.

$\mathrm{Zij}$ vertrekken weer langs dien weg. Als Koranobini wakker wordt en die vrouw niet ziet, achtervolgt hij Mĕrāksamana en de zijnen op dien weg. Maar als zij het strand van hun land bestijgen, 
braakt Mandinuma al het water weer uit, zijn buik leeg en Koranobini verdrinkt.

Mĕrāksamana brengt de vrouw weer naar zijn huis. Maar de vrouw stijgt weer ten hemel, omdat de jongens haren zoon uitjouwen, zeggende: ze kennen de verwanten van zijne moeder niet.

Mĕrāksamana gaat ook naar den hemel, om de vrouw te zoeken.

't Overige verhaal, gelijk in $\mathrm{N}^{\circ} 33$.

A ant. I. Koranobini. De naam beteekent de vrouwen korano. Korano van Kolano.

2. Op blz. 8 van de Spraakk. der Nuf. taal behandelde ik de bet. der w.w., die door herhaling worden gevormd. Ze duiden als: a nan (eten) van an, banban (reinigen) vau ban, een voortdurend reinigen aan. Beperkt zich het eten tot sago en het reinigen tot een bord, dan wordt alleen a n en ba n gebruikt. Zoo duidt in deu zin een bij herhaling genoemd w.w., ook een herhaalde, een voortdurende werking aan.

3. Miun. Is mun (treffen) met het ingevoerde pers. vnw. v./d. $3^{\circ}$ pers. i. Zie: Spraakk. der Nuf. taal, blz. 16.

4. Maudinuma (lett. de drinkende man). Het Nuf. woord voor drinken is inēm. Prof. Keru in de "Verhouding van het Maf. tot de Mal. Pol. talen merkt" echter op: in u m M.P.

5. Mērvēr. Is weigeren, doch ook, z. a. in dezen zin, iets niet langer willen, iets wegwerpen, wegdoen.

6 Of. Zich zelven verbergen, ōkēf iets of iemand anders verbergen.

7. Geen verwanten te hebben is zooveel als slaaf te zijn.

35. Snungubur i sjow ĕr ikāk.

Naikri suru, su pōs in, su biser, su mām sra. Bĕba i d'ek sra, bape ikāk kōrwēn i mgu( $\left.{ }^{1}\right)$ wārk sra ro fandu. Rumgun běba i d'ek sra, i kōfein faro ikāk: „Wa bur, wa dwark awer, j'ek sra rēsĕri". Bape ikāk i meōfba. Rumgun i kōfein : "Nēri ja bak mawōn piuper faro au". Bape ikāk i meōfba, i kein munda. Rumgun, i kōfein wer: Nēri ja bak pānda, i fnōk mawōn !" Bape ikāk i meōfba. Āusōna wer, rumgun i kōfein : "Nēri ja bak sraar jedi faro au !" Ānsōna ikāk, i marisein.

Rumgun, i d'ek sra kwar, i sabu.

Ma i kukĕr běkuìk, su j'ek wa, ma su wan ikāk, i barek ro wa raundi. Su rama ro rum, srar si waf rumgun su. Si mām ikāk, 
si mkak, si kōfein: "Ikāk, nēri i min ko!" Bape nei bĕkuīk, i marisein, i buk ikāk.

Riani ikāk i d'ek be nei sim bjeda.

Ro isna, ikāk i barēk ro sōp, bape mandira i sasiar rib bjeda, ma i bĕsnunkaku. Isna i sjowĕr wer ro rib.

Māndira ōso, běba i knenĕf ro pangir ro sim, i kandor snunkaku, snungobor bĕbje. I d'or běknìk bjedi, ma su ra ro sim, ma su kōfein faro bĕknìk, si buk i kaim. Bape nei i meōfba, ma snungobor ani kakō, i kōfein : "Mu meōf aja ba, mu j’amnēf aja, ansōna ja meōf mu ba.

35. De jongeling die zich als slang vermomde.

Twee broeders, die aan het visschen waren, kregen honger en zien een kokosboom.

De groote klimt in den kokosboom, maar een reuzenslang belemmerde hem in zijn klimmen. De oudste, jongen, die in den kokosboom klom, zeide tot den slang: "Ga weg, verhinder mij niet, laat mij eerst in den kokosboom klimmen." Maar de slang wilde niet. De jongen zegt: "Ik zal een witten gong aan u geven." Maar de slang wilde niet, hij bleef maar. De jougen zegt weer: "Ik zal een geweer, bij deu gong geven!" Maar de slang wil niet. $\mathrm{Nu}$ zegt de jongen weer: ik zal mijne zuster aan u betalen!" $\mathrm{Nu}$ was de slag tevreden.

Als de jongen de kokosnoten geplukt heeft, daalt hij weer af.

En hij met zijn jongere broer, zij stijgen in de prauw en ze bevelen den slang, te gaan liggen in het vóór-gedeelte der prauw. De jongens worden door hunne zusters bij hunne tehuiskomst gewacht. Als ze den slang zien, vreezen ze, zeggende: "De slang zal ons dooden!" Maar het jongste meisje wil wel den slang huwen.

Daarom klimt hij in 't kamertje van het meisje.

Overdag ligt de slang op den grond, maar 's avonds komt hij uit zijn huid en hij is mensch. Als het licht wordt, omhult hij zich weer met het vel.

Op een avond tuurt de oudste door een gaatje in de kamer, ze is verbaasd een mensch te zien, een schoonen jongeling. Zij roept hare jongere zusters en ze gaan naar de kamer en zij zeggen, dat zij hem allen huwen willen.

Maar het meisje wil niet en die jongeling wil ook niet, hij zegt, "Gij beiden wildet me niet, gij hebt me gespogen, nu wil ik u beiden niet," 
A a nt. l. Mgu. In dit verband is dit woord me niet duidelijk, daar het woord beteekent jong en jongen (baren). Of het nog een andere bet. heeft, weet ik niet. W a rk is beletten, belemmeren.

36. Snungobor i sjowĕr ingōmbārarē.

Kĕbom ōso, i nei rumgun kukĕr nei. Bin, i sma aipa, i buk i faro nai, i kōfein: "Wa fnap i, ma srar bedi kianēs, wa buk rwapim kapirare faro $i$, bape $i$ d'an rwapim bĕba awer. Ma snari, i bur.

Rumgun kapirare i kanēs māngĕnem, srar bjedi, i buk rwapim běba kakō faro i fa i d'an.

Bin, i sibĕr ,wer, i mām aipa krāf munda, i fuken : "Rwapim běba i sia ro ?" Nei i kōfein : "Rumgun kapirare kianēs māngĕnēm, ja buk rwapim kām faro i.”

Snari i msor, i bur. I bur kwar, rumgun kapirare i pisak, i kanēs kuker snari. Srar bjedi, i kōfein : "Sasār mangunbeda! I msor, au w'an rwapim nakaim ro aipa. Bape, nēri ku serf i."

Su mam snari weur bjena, su jom i, sōf su mām, snari i rir ro nejān bori sus (1), mangkōko pěnōr kuker amiun. $\left({ }^{2}\right)$ Su j'an i bro, su jom snari wer. Snari, i mbrein pōn, sōf i mām snun bĕba, snōriso Rēgĕrēgĕ, i bas sbari ; ma snari, i mbrein ro dōri. Rēgĕrēgě, i d'ōrĕn i sipěr. Bape snumburaim, na kein ro nasi bjeda kaker.

Rumgun ma nei, su jom bin, su mām Rēgĕrēgě kakō. Bape nei i kōfein : "W'akmām snun ōrně, i d'ōrĕn nani kwar, snumburaim bjena na sia ro nasi bjedi kaker. Su bur be rum seda wer.

Nei i fan srar bjedi, sōf i ba. I besnungobor, i mbrein i rama ro mēnu ōso. Snungobor ro mēnu ōrja, si fnāk sārma. Snungobor ani, i d'akfnāk ma ōso, i pōk i ba. $\left({ }^{3}\right)$

Warpur wer, i mbrein be mēnu ōrja, si wan mangkoko snun, si muniai si. $\left({ }^{4}\right)$ Snungubor ani, i kakō, i d'un mangkōko bjedi, mangkōko kapirare kaku. Si mām i, si kĕrjair mangkōko, si kōfein: "nēri i pōkba beri". Bape snungobor ani mangkōko bjedi, i mun mangkōko snun kām ro mēnu ōrja, rjani i sma untung běba. I pōkba, i bar kumpāng nakam, i běsewa Tjina i d'un kumpāngua be rum.

Rāso wer, i kōfein faro srandi : "Wa ra be mānsĕrēn ro mēnu ōrja, w'or ōso ro nei bjesi, ja buk i. Srandi, i mkak, bape snungobor i kōfein: "Wa ra wauĕrik, ma srandi i ra, bape i ma $\left(^{5}\right)$, i d'orěs běkwaim. Māusěrēn i mām i, i wan ōso ro kawāsa bjedi, i d'or nei. Ma nei i d'or ōso ro radja nei bjesi be swa $\left(^{6}\right)$ ro sraudi 
bjedi. Mānsěrēn i kōfein : "I bje, bape i frur rum sarāk maro aja rēsĕri". Nei i kōfein : "I bje".

Ma snungobor i kōfein wos ōser ma rum sarāk i sia. Ānsōna i mbrein be mānsĕrēn ro mēnu ōrja, bape i sjowĕr mangundi ro ingōmbararē ribja. Ma iriria i d'ōpĕr ro nejān be mānsĕrēn.

Ingōmbararē i barēk ro mānsěrēn ani awēk, mānsĕrēn i d'or nei běba ; i fukĕn i : "Wa marisein, wa buk?" Nei bĕba i d'aninēf i, d'ōbo: "Ja buk inke?" Nei fandu, i kakō i mēwĕr. Radja i d'or nei běknìk, i kōfein: "Au, wa buk ingōmbararē?" Ma i kōfein: "Ja marisein !"

Iriria ingōmbararē i d'ènēf ro nei bĕknìk sim bjeda. Isua i sjowĕr i ro ingōmbararē ribja, ma i barēk ro sōp, bape māndira i sasiar ma i kein kukĕr bin.

Bĕba, su pangaken $\left({ }^{7}\right)$ ārsēn ro běknìk seda sim bjeda fa si mām wārk ingōmbararē kukĕr naik sedi. Su man snungobor bĕbji, su kāndor ma su marisein su buk i, ma su msor bĕkuîk, snar i buk roběan ro obēk munda, bape běknìk, i kōfein : "Wa mam, i rariria kwar".

Su marisein, su buk snungobor ani, bape i mēwĕr. Ānsōna běba, - su msor i, su marisein, su mun i. Rjani su frur robĕan faro i, ma su papiar rēt posom. Bin i d'an roběan rēsěri - kōfein faro swari : "W'an roběan ōrnĕ awer, su papiar rēt posom". Rāso wer, běba, su frur robĕan, su pāpiar rātjōng. ${ }^{8}$ ) Bin i d'an rēsěri, i kōfein faro snun : "W'an awer, su pāpiar rātjōng".

Ānsōna, suun i kōfein: "Ku bur, rās ōso su mun ajake, au ke!"

Ma kapāl, i rama, i d'un su be snun rum bjeda. Srandi, i waf su, ma snun, i kōfein: "Wa farbukbe?" I kōfein : "Roba, ja meōfba, ja kein so au munda!"

36. De Jongeling, die zich als bruinvisch vermomde.

Eene weduwe had eeu zoon en eene dochter. De vrouw vond een krab, die zij an het meisje gaf, zeggende: "Kook die en als uw broer huilt, geef hem dan den kleinen vinger, maar hij mag den grooten vinger niet eten. En de moeder vertrok.

De kleine jongen huilt zoo, dat zijne zuster den grooten vinger ook aan hem te eten geeft.

Toen de vrouw weer terugkeerde, zag ze het lichaam van de krab slechts en ze vraagt: "Waar is de groote vinger?" Het meisje zegt: "De kleine jongen huilde zoo, dat ik hem al de vingers gaf".

De moeder werd boos. Toen ze weg was, werd de kleine jongen 
wakker en weent om zijne moeder. Haar broeder zegt : "Je eigen schuld! Ze werd boos, omdat je al de vingers van de krab hebt opgegeten, maar we zullen haar zoeken".

Als ze de voetsporen van hunne moeder zien, achtervolgden zij haar, tot zij zien, dat de moeder op den weg gelegd had melk, kippe-eieren en mandjes rijst. Na gegeten te hebben, achtervolgen zij de moeder weer. De moeder loopt vooruit, tot ze eenen grooten man ziet, wiens naam was Rēgěrēgě, die zijnen mond opendeed; en de moeder liep er in. Rēgĕrēgě slikte haar geheel in. En de haren blijven nog tusschen zijne tanden.

De jongen en het meisje, die de vrouw achtervolgden, zien Rēgĕrēgĕ ook. Maar het meisje zegt: "Zie dien man, hij heeft moeder ingeslikt, hare haren zijn uog tusscben zijne tanden." Zij keeren weer naar hun huis.

Het meisje voedt haren broeder, tot hij groot is. Jongeling geworden, gaat hij eens wandelen en komt in een dorp. De jongelingen uit dat dorp spelen bal. Die jongeling speelt mee en niet éen, die tegen hem opkon.

Later weer gaat hij naar dat dorp. Nu houden ze hanengevechten. Die jongeling had ook zijn haan meegebracht, een zeer kleinen haan. Als ze dien zien, schimpen ze op den haan, zeggende : "hij zal zeker niet overwinnen". Maar de haan van dien jongeling doodt al de hanen van dat dorp, dat gaf hem groote winst. Hij kon al het geld niet dragen en huurde daarom een Chinees, die het geld naar huis bracht.

Op zekcren dag zegt hij tot zijne zuster: "Ga naar den heer van dat dorp, vraag ééne zijner meisjes, dat ik haar huw". De zuster is bang, maar de jongeling zegt: "Ga maar!" En de zuster gaat, maar ij is verlegen, ze staat van verre. Als de heer haar opmerkt, zondt hij een van zijn volk, om het meisje te roepen. En het meisje vraagt een van de meisjes van den koning tot vrouw voor haren broeder. De heer zegt: "'t Is goed, maar hij moet eerst een zilveren huis voor mij maken". Het meisje zegt: 't Is goed!"

En de jongeling spreekt één woord en het zilveren huis is er. $\mathrm{Nu}$ gaat hij naar den heer van dat dorp, maar hij vermomt zich zelven in het vel van een bruinvisch. En zoo vermomd springt hij op den weg naar den heer.

De bruinvisch ligt aan den trap van dien heer. Die heer roept zijne oudste dochter; en vraagt haar: "Wilt gij hem huwen?" Het oudste meisje spuwt hem, zeggende: "Zou ik een visch huwen?" 
Het middelste meisje wil hem ook niet hebben. De koning roept zijne jongste dochter, zeggende: "Huwt gij den bruinvisch?" En zij zegt : "Ik wil!"

Alzoo slaapt de bruinvisch in het kamertje van de jongste dochter. Overdag vermomt hij zich in het bruinvissche-vel en hij ligt op den grond, maar 's avonds komt hij er uit en blijft bij de vrouw.

De twee ouderen maken een opening in den wand van het kamertje hunner jongere zuster om te letten op de bruinvisch met hunne zuster. Als ze een schoonen jongeling zien, zijn ze verbaasd en ze willen allen hem huwen en ze zijn boos op de jongere, omdat ze eten geeft in een klapperdop, maar de jongste zegt: "Zie maar, hij is zóó" (dat is zóó zijne gewoonte).

Zij willen dien jongeling huwen, maar hij wil niet. Nu zijn de ouderen boos op hem en willen hem dooden. Daarom maken ze eten voor hem en ze vermengen het met naaldepunten. De vrouw eet het eten eerst en zegt dan tot haren man: "Eet dit eten niet, ze hebben er naaldepunten doorgemengd." Op een anderen dag hebben de ouderen eten gemaakt en hebben er vergift in gemengd. De vrouw eet eerst en zegt dan tot den man: "Eet niet, zij hebben er vergif doorgemengd."

$\mathrm{Nu}$ zei de man: "Wij gaan heen, op een dag zullen ze mij of u dooden!"

En een schip komt, dat hen beiden naar hun huis brengt. De zuster wacht op hen en de man zegt: "Zijt ge niet getrouwd?" Zij zei : "Neen, ik wil niet, ik blijf slechts bij u!"

A ant. 1. Sus. Melk, n.l. van haar zelve.

2. Amiun. Reeds vroeger is opmerkt, dat dit zoowel kan beteekenen djamboe-vrucht als kĕtoepats.

3. Ōso i pōk i ba. Pok is kunnen en ook krachtig zijn. Ōso i pok i ba. Niet één is zoo krachtig als hij. Niemand kan hem aan.

4. Hanegevechten kennen de Papoea's niet. Uit het vermelden van hanegevechten en uit nog meer in dit verhaal, blijkt, dat het overgenomen is.

5. Ala. Verlegen, beschroomd.

6. S wa. Echtgenoot. Doorgaans hoort men s wa-ri. Waarschijnlijk is $\mathrm{ri}$ echter een soort bep. lidw. en beduidt $\mathrm{swari}$ de man of de vrouw.

7. Pāngakĕn. Eene opening maken om door te kijken. Pangir 
is opening, gaatje. Hoe de wijze van -afleiding is, weet ik niet.

8. Ratjōng. De Nufooren hebben een eigen woord voor vergif, n.l. marmur. Onder ratjong wordt 't meest verstaan 't rattenkruid, dat noodig is bij 't opzetten der vogels, 't voornaamste handelsartikel der Nufooren.

37. Inkonkuburi. (')

Māmbĕnaik, běba, bĕkanìk, su snōsna: Sĕramaniraï,

Su nai srar ōser.

Ōrja $\left({ }^{2}\right)$, Sĕramaniraï i wan srandi, d'ōbo: "Wa kēruk jar $\left({ }^{3}\right)$, fa ja kur saurir". Rēsěri srandi kōfein: "Aja kēruk jar fa wa kur saurir, w'ajujĕn Inkonkuburi ro Sorēndiweri, wa buk i fa ja bĕnai refiobini". "Wa kēruk wauĕrìk, j'un ke, roba ke!", Sěramaniraï i kōfein.

Saurir, i d'ajujĕn fa i d'un bin, srandi i kōfein ani ro Sorĕndiweri.

I d'ajujĕn, snon ro Sorĕndiweri s'ōbo: "Wa roriso?" I kōfein: "J'un Inkonkuburi." (I sma kubur, bin, i d'enēf ro dōri). I d'un i bur, bin wēsě d'ōbo: "Aja Inkonkuburi, ōrně roiam wauěrík !" Sĕramanirai i san kubur ro wa dōri ma i d'un bin bĕsrer ani ma i buk i.

Bin ōrnĕ, snōriso Indowauěrìk.

Ōrja i buk Indowawěrik, i d'un be rum, kukĕr kubur, Inkonkuburi i sia ro dōri.

Rēesĕri Sĕramanirai kawāsa bjedi s'om diaf. Si bor bur rumia, Inkonkuburi i sasiar fa i d'an robĕan, i masi, suumburaim bjena brawĕn, bape i kwaim kaku imnis njonja.

Rēešri, wam i sjo. I swar wamia, d'ôbo: "Wam i sjo ro nani, mami sup subeda, su fauba, su j’ōbo: "Ja ramaja, buk snon. Bape roba, ja kon wauěrìk, ja buk snōnoba".

Māusar öso, i mbrēin napōkba, i so kawāsa ba, s'om diāf, i kein ro rum. I mnāf ōso i d'awěs, i d'orĕs, i mām Inkonkuburi. I mam bin, māusar i kōfein : "Bin insěrēu kaku( $\left(^{5}\right)$ îs ōrně. Sĕramanirai i d'un Indowawěrik, bape Inkonkuburi is ōrně."

Mānsar i d'ōf wer, Inkonkuburi i sjun ro kuburia dōri.

Māndira Sĕramanirai kawāsa bjedi, si mgir, mānsar ani i d'or Sĕramanirai : "W'un sambako ma j'akan." Sĕramanirai i kōfein : "Rās inẻ mānsar i d'or aja, i sma rosei ?" Indowawĕrîk i swarepĕn rape: "Mansar i kōfein ro Inkonkuburi !"

Inkoukuburi, i masi i ris snumburaim, ōso i sapi. Inkonkuburi i sjun kubur bjeda, mānsar i d'un fasau. Mānsar i fasıa faro 
Sĕramauirai, d'ōbo : "Snumburaim Inkonkuburi is ōrnĕ. Inkonkuburi kaku i sia ro kubur dōri - wa buk Indowawĕrìk, i srer au kwar."

Sĕramauirai d'ōbo: "Kaku, neri mèsĕr ja bur angar be sup, ja bur ma wer, j'ōf ro waia dōri arĕn, ja mām i sasiar wer."

I d'ōf arkōk kaku, i d'awĕsba, i kein fasis.

Arkōk kaku. Inkonkuburi i sasiar wer, i d'an robĕan, i masi, i mbrein jar rumia, i d'awĕs, i kōfein: "Wamia, wa sjow nani, mami sup subeda", imnis rāsowinda.

Rēsĕri Sĕramanirai i d'ōpĕr, i kin Inkonkuburi ro rwasi, d'ōbo : "Wa jōkĕf-au ro kuburia dōri." Bin i kōfein : "W'un aja, rēsĕri wa buk Indowawěrîk."

Sĕramanirai d'ōbo: "I bjo kwar, ja mēwĕr i rape, ja buk au wauĕrìk."

Māndira kawāsa Sĕramanirai bjedi, si mgir ro rum, si mām Inkonkuburi. Sĕramanirai srandi i marisein d'ōbo: "Rĕfiobin kaku jedi ìs ōrně." I forepĕn i, i sjum i, i buk roběfa, sāmfar, sarāk faro refiobin bjedi, i jau Indowawerik.

\section{Inkonkuburi.}

Er waren twee broeders, zij heeten: Serramanirai en?

Ze hadden ééne zuster.

Sĕramanirai beval zijne zuster, zeggende: "Snijd pandanusbladeren, opdat ik een zeil make." En toen zei de zuster: "Ik snijd pandanusbladeren, opdat ge een zeil zoudt uaaien, om te zeilen naar Inkonkuburi te Sorēndiweri; huw haar, opdat ik hebbe eene schoonzuster". "Snijdt gij maar, misschien haal ik haar, misschien uiet!" zei Sĕramanirai.

Het zeil zeilde om de vrouw te halen door de zuster bedoeld, te Sorēndiweri.

Als hij komt aanzeilen, vragen de mannen van Sorēndiweri zeggende: "Waar gaat ge heen?" $\mathrm{Hij}$ zeide: "Ik haal Inkonkuburi" (De vrouw had een tritouschelp, warin ze sliep). Als hij die schelp weghaalt, zegt eene andere vrouw: "Ik ben Inkonkuburi, dat is een gewone schelp!" Serramanirai wierp toen de tritonschelp in de prauw en hij neemt die leugenaarster mee en huwt haar.

Deze vrouw heette Indowawerìk.

Alzoo neemt hij Indowawerīk, die hij heeft gehuwd, mee naar huis met de tritonschelp, waarin Inkonkuburi is.

En toen ging het volk van Sĕramanirai een tuin ontginnen. Toen ze het huis verlaten hadden, komt Inkonkuburi er uit om te eten 
en te baden; hare haren zijn als goud, maar zeer lang z.a. eene njonja.

En toen begon de wind zachtjes te waaien. Ze hield van den wind, ze zegt: "Wind, die in het.land van mijne moeder en mijnen vader waait, zij weten van niets; zij zeggen, dat ik gekomen ben en een man heb gehuwd. Maar neen, ik zit zoo maar, ik heb geen man gehuwd."

Een grijsaard, die niet loopen kon, was niet met het volk meegegaan, dat een tuin ontginde, hij was thuis gebleven. Toen hij iemand hoorde spreken, staat hij op en ziet Inkonkuburi. Als hij eene vrouw ziet, zegt de grijsaard: Dat is een echte vrije vrouw. Sĕramanirai heeft Indowawerik meegebracht, maar dat is Inkonkuburi".

De grijsaard verborg zich weer en Inkonkuburi trok zich weer in de tritonschelp terug.

Als het volk van Sĕramanirai uit het boch thuisgekomen is, roept die grijsaard tot Sĕramanirai: "Breng tabak en ik zal meeëten." Sĕramanirai zegt: "Wat heeft de oude vandaag, dat hij mij roept?" Indowawerik denkt al: "Die grijsaard spreekt van Inkonkuburi!"

Toen Inkonkuburi baadde, had ze de haren gekamd - en één haar was gevallen. Toen Inkonkuburi in hare schelp was gegaan, haalde de oude man dit spoedig. De oude man toonde het an Sĕramanirai, zeggende: "Dit is een haar van Inkonkuburi. De echte Inkonkuburi is in de schelp — gij hebt Indowawerik gehuwd, zij heeft u belogen."

Sĕramanirai zegt: "Juist, wacht, morgen zal ik doen of ik naar het bosch ga, dau kom ik weer terug, en verberg mij in het zoldertje van de prauw, dan zie ik haar als ze er weer uit komt.

Hij verbergt zich tot den middag en spreekt niet, hij bleef stil zitten.

Op den middag, komt Inkonkuburi naar buiten, ze eet voedsel, ze baadt, ze loopt om het huis, ze spreekt, zeggende: "Wind, gij waait in het laud van mijn vader en mijne moeder." enz. gelijk gisteren.

En toen springt Sĕramanirai op, hij grijpt Inkonkuburi bij de haud zeggende: "Waarom verbergt gij $\mathrm{u}$ in de schelp". De vrouw zegt: "Waarom haalt ge mij en waarom huwt ge dan Indowawerik".

Sĕramanirai zegt: 't Is uit, ik wil haar niet meer, ik huw u maar.

's Avonds komt het volk van Serramanirai uit het bosch in huis eu zij zien Inkonkuburi. De zuster van Sĕramanirai is blij, ze zegt: 
"Dit is mijne echte schoonzuster". Ze omhelst haar, ze kust haar, ze geeft een oorring, een schelpen armband, een zilveren armring aan hare schoonzuster en ze jaagt Indowawerik weg.

A ant. 1. Inkonkuburi. In (im voor b.) is de aanduiding van den vrouwelijken vorm tegenover $\mathrm{m} \overline{\mathrm{a}} \mathrm{u}$, (ma m voor b) den vorm vau het manu., z.a. insar (oude vrouw), mānsar (grijsaard), i mbaniori (schoonmoeder), ma mbaniori (schoonvader). Kon, nevenvorm vau kein, zitten, vertoeven, verblijven. Kubur, tritonschelp, dus de vrouw, die verblijf hield in de tritonschelp.

2. $\bar{O}$ rja. Dat in tegenstelling van ōrn é, dit. Menigmaal echter komt het ook voor aan het begin van een zin, zonder eene bepaalde bet. Zooveel als het Mal. bag it u.

3. Jar. Een pandanus-soort, welks bladeren, aan elkander genaaid, zich goed leenen tot matten en ook tot zeil.

4. Kur. 't Samenvoegen der pandanusbladeren, 't aaneenrijgen.

5. Insĕrēn kaku. I u sěrēu, vrije vrouw tegenover mansěrën heer, vrije. Kaku, echt. De Nufooren onderscheiden hunne standen naar de afkomst van vrijen en slaven. Iemand, ouder wieus voorouders geen slaaf is aan te wijzen, heet ins ĕrēn, of mānsérēn $\mathrm{kaku}$, of ook wel : in zijn (haar) bloed is geen druppel lood, 't is louter zilver (of goud). Het water, waarmee een slaaf gedoopt wordt, die tot kind wordt aangenomen heet men ook zilver- of goud-water. 't Gebeurt wel, dat derde of vierde zoons van vrij-geboren om de hooge bruidsschat zich moeten vergenoegen met eene slavin, die hun aangewezen wordt. De kinderen uit zoo'n huwelijk gelden niet als iusěrēn of mānsĕrēn kaku.

\section{8. (1) A burēi.}

Rumgun, si kfo in, si mām nāsěm $\left({ }^{2}\right)$ karifjom bōn, i piar i da. Si serf knām bjeda, Si mām knäm, rumgun mĕngābo i d'ek bĕpōn. Rumgun wēsě, si msor mĕngābo, si prer i. Mĕngābo $\left({ }^{3}\right)$, i suēri sām i d'or Aburēi, běnai ro nāsĕm : "Aburēi, d'eko d'ekě d'eko!" ( $\left.{ }^{+}\right)$ Aburēi i kar wa, i mnāfba, bape swari d'ōbo : "Aburēi, s'or au!" Aburēi, i mbrein be knām, bape i mām romawasi maroba, s'ōf ro nāsĕm ruri; mĕngābo i d'ōf ro kāngōmbe. $\left({ }^{5}\right)$

Aburēi i mām rumgun ōsoba, i bur. Mĕngābo i d'or wer: "Aburēi d'eko d'ekě d'eko!"

Iriria běkiōr, i sma mĕngābo ro kangombe. Mĕngābo i d'āp rumgun si snōsna. Aburei, i mām si, i for si kām, i d'âfĕn si 
kām ro rōnan $\left({ }^{6}\right)$ bĕba kaku, ma i bur fa i serf amiais, i kun si. Bape rumgun, si frur pāngir ro rōnan kukĕr mĕngābo ani, ino bjeda.

Su bur, si kapu ro rōnan dōri, rōnan i fo, rēsĕri si frar, ma s’ek kinĕmknām. ( ${ }^{7}$ ) Aburēi, i fauba si bur kwar, i so mĕnōf bjeda be rōnan. Bape rumgun ōsoba, kapu seda munda. I serf si wer, i mām si ro kinĕmknām. I meōf, i perĕm knām kukĕr si. Aburēi i perĕm ro mun wēsĕ, kāpāuanir i reb kukĕr kaprendi, ai, i sipĕr wer, ma i kofein : "Reběrebĕ a i kuk!" Aburēi i mam kāpānānir, i kēruk kaprendi, ānsōna knām, i kar. Aburēi, i kōfein : "Karokari, kiar i kar." ( $\left.{ }^{8}\right)$

Knām, i sāpi kukĕr rumgunsi fanām wai Aburēi, i kar ani, ma rumgunsi s'ek wa bĕri ma si borĕs.

Aburēi, i pas kum bjena kām, i pām na ma i so rumgun wa seda kukĕr jāfĕn. Jāfĕn i kiur wa ma i sjob wa. Bape rumgun s'un maujowi, i kēin ro ādi. Ma manjowi i d'ark abra kum i muk. Aburēi i pām fasau wer, ma i so wer, bape maujowi i d'ark wer. Iriria isōf abra i bro, ma rumgun, si bur be rum sena.

\section{A burēi.}

Eenige jongens, die aan het visch schieten waren, zagen de vrucht van een djamboe drijven. Ze zochten den boom. Als ze den boom zien, klimt een jongen met bobento het eerst er in. De andere jongens werden boos op den jongen met bobento en slaan hem. De bobento-lijder wordt boos en roept Aburēi, den eigenaar van den djamboèboom: "Aburēi, klimmen, klimmen!" Aburēi, die eene prauw makt, hoort niets, "maar zijne vrouw zegt: "Aburēi, ze roepen je!" Aburēi loopt naar den boom, maar hij ziet de jongens niet, want ze hebben zich in den top verborgen, de bobento-lijder verborg zich in een groote schelp.

Aburēi, die geen enkelen jongen ziet, gaat heen. De bobento-lijder roept weer: "Aburēi, klimmen, klimmen!"

Zoo geschiedt het drie malen, en nu vindt hij den bobentolijder eu de schelp. De bobentolijder noemde de namen der jongens. Aburēi, die hen ziet, vangt hen allen en stopt hen allen in een zeer groote ronan, en hij gaat heen om brandhout te zoeken, om hen te roosteren. Maar de jongens maken een gat in de rouan, met het mes van den bobento-lijder.

Terwijl ze heen gaan, doen ze hunne behoefte in de ronan, de ronan vol en dan vluchten ze en klimmen in een kinemboom. Aburēi die niet weet dat ze gevlucht zijn, werpt zijn speer naar 
de ronan. Maar geen enkele jongen is er, hun str... alleen. Hij zoekt hen weer en vindt hen in den kinemboom. Hij wil den boom omhakken met hen allen er in. Als Aburēi aan den anderen kant wil gaan hakken, likt een hagedis met zijn tong den boom weer heel en zegt: "Likken, likken het afgeknabbeld hout." Aburēi de hagedis ziende, snijdt de tong door, nu breekt de stam. Aburēi zegt: "Hakken, hakken, hij breekt."

De boom, met de jongens, valt dichtbij de prauw, die Aburēi an 't hakken is, en de jongens klimmen spoedig in de prauw en ze roeien weg.

Aburēi trekt al zijne lichaamsharen uit, hij knoopt ze aan elkander vast en hij werpt de prauw der jongens met zijn harpoen. De harpoen treft de prauw en hij trok de prauw. Maar de jongens hadden een papegaai meegenomen, die op den uitlegger zat. En de papegaai bijt in het harentouw, zoodat het breekt. Aburēi kuoopt het weer spoedig aaneen, en de papegaai bijt er weer in. Dat gebeurt tot het touw op is en de jongens gaan weer naar hunne huizen.

A a nt. 1. De meeste vertellingen hebben haren eigenaar of eigeuares, die het alleen mogen verhalen, naar wie men verwijst, indien men een of ander verhaal nog eens zou willen hooren. Het verhaal van Aburēi is algemeen bekend, en wordt algemeen verteld.

2. Nās ĕm op Nieuw-Guinea komen vele djamboe-soorten voor. De nāsĕm is de z.g.n. djambu-ajer, die ook alweer in grooter of kleiner soort onderscheiden wordt. De nās ĕm karifjom is de grootere soort.

3. M ĕngāho, kinderen of volwassenen, behebt met eene of andere ziekte, worden dikwijls met den naam hunner ziekte genoemd.

4. $\mathrm{Ek}$ is klimmen. In verhalen, waarin uitroepen voorkomen, en ook in versjes worden de w. w. wel verlengd.

5. Kāngombe. Groote schelp, die dichtslaat als een oesterschelp.

6. Ronan. Eeu vat, gemaakt van boombast, die van den stam wordt losgemaakt. De bast heeft den vorm van den boom behouden en de uiteinden worden alleen bevestigd, en een bodem er aan gemaakt.

7. De kin ĕm is een hooge, dikke boom.

8. $\mathrm{Kar}$ is omhakken, doen breken en breken, omvallen van boom.

$\mathrm{Si}$ kar ai. Ze hakken een boom. Knam i kar. De boom is gebroken. 


\section{B a d a sināng.}

Ro mēnu ōso, snun i kēin, snōriso Badasinang. Snun ōrnĕ i sma rwa ōser, kna ōser, mga ōser, we ōser, imnis si kes i.

Ras ōso, si rib djarāk (') ro kajĕn. Ōso, i rib djarāk kukĕr snau suru, wēsĕ kukĕr snau kiōr, wēsĕ wer suau fiāk, bape Badasināng i rib djarāk kukĕr snau di war.

Mananur ro meno i mām djarāk, si rib ro kajĕn, i fukĕn: "Mundiri i rib djarāk kukĕr snau di nar?" Si kōfein: "Ōrnĕ Badasināng djarāk bjedi. Mananur i wan Badasināng, d'ōbo : "Wa mbrēin, wa serf djarāk kukĕr snau di war."

Badasināng i mbrēin. Ro mēnu, i rama bĕpōn, si mam i, si mkak, si kōfēin : "Badasināng, si kōfēin ani, i serf rosei ?" Mananur ro mēnu ōrja, i kōfēin : "Mgo mkak awęr, — ko fukĕn, i marisein rosei." Ma Badasināng i fukĕn: "Djarāk kukĕr snau di war is ōrjake?" S'ôbo: "Roba, snau kiōr kada i sia, snau fiāk i isia, bape snau di war, ko sma ba.

Badasināng i d'enĕf ōrwa, ma isna, i bur wer, i serf djarāk kukĕr snau di war ro mēnu bĕsuru. Ōrwa kakō, si mkak i, bape mananur i kōfēin wer: "Mgo mkak rosei, ko fukĕn, i serf rosei. Ma Badasināng, i kōfēin wer: "Ja serf djarāk kukĕr suau di war. Ōrwa, si kōfēin wer : "Djarāk kukĕr snau di kiōr i sia, kukěr snau di fiāk i sia, bape kukĕr snau di war ko sma ba.

Iriria i serf ro mēnu kām, isōf i rama ro menu napembĕr.

Ōrwa si kōfēin : "Djarāk kukĕr snau di war i sia, kukĕr samfur i sia, kukĕr samfur di suru i sia. Mangundau !"

I fukĕu djarāk kukĕr snau di war.

Mandira si fau djarāk, si fes djarāk kukĕr suau di war, ma isna Badasināng i d'ek djarāk bjedi, ma i rir gomōra $\left({ }^{2}\right)$ suru ro sbari. I marisēin djarāk i mbrēin be rwa sar, Badasināng i sjob ro gomōra rwa sar; be rwa kaku, i sjob gomōra ro rwa kaku. Ma iriria i d'un djarāk kukĕr snau di war be mēnu bjeda. Mananur ro mēnu, i mām i, i marisein i, i sandik i.

\section{Badasināng.}

In een dorp woonde een man, wiens naam was Badasināng. Die man had één arm, één oor, één oog, één been, alsof men hem gespleten had.

Op een dag teekenden zij paarden in het zand. Eén teekende een paard met twee hoornen, een ander met drie hoornen, een 
ander weer met vier hoornen, maar Badasināng teekende er een met acht hoornen.

De hoofdman van dat dorp, ziende de paarden, die ze in het zand hadden geteekend, vraagt, wie dat paard met acht hoornen geteekend heeft. Ze zeggen: "Dat is het paard van Badasināng." De hoofdman beveelt Badasināng, zeggende: "Ga, zoek een paard met acht hoornen".

Badasināng gaat. In het dorp, waar hij het eerst komt, ziju ze bang, als ze hem zien, ze zeggen: "Dat is Badasināng, van wien meu zooveel spreekt, wat zoekt hij?" De hoofdman van dat dorp zegt: "Vreest niet, - we vragen, wat hij wil". En Badasināng vrangt: "Is daar een paard met acht hoornen?" Ze zeggen : Neen, een met drie hoornen, die is er wel; met vier hoornen is er ook, maar met acht hoornen hebben we niet."

Badasiuāng slaapt daar en toen het licht werd, ging hij heen, om een paard met acht hoornen te zoeken in het tweede dorp. Daar zijn ze ook bang voor hem, maar de hoofdman zegt weer: "Wat vreest gij, wij zullen vragen, wat hij zoekt». En Badasināng zegt weer: "Ik zoek een paard met acht hoorneu." Dáár zeggen ze weer: "Een paard met drie hoornen is er, met vier hoornen is er, maar met acht hoornen hebben we niet."

Zoo zoekt hij in alle dorpen, tot hij komt in het uiterste dorp. Daar zeggen ze: "Een paard met acht hoornen is er, met tien hoornen is er, met twintig hoornen is er. Ge moet 't zelf weten!"

Hij vraagt een paard met acht hoornen. Als ze 's avonds de paarden voeren, binden ze er een vast met acht hoornen en toen het licht werd, besteeg Badasināng zijn paard en hij legt twee haken in den bek. Als hij wil, dat het paard naar links loopt, trekt Badasināng aan den linkerhaak; naar rechts, dan trekt hij aan den rechterhaak. En zoo brengt hij het paard met acht hoornen naar zijn dorp. De hoofdman van dat dorp hem ziende, is tevreden over hem en prijst hem.

A ant. 1. Djarak. Paard. De Clereq teekent omtrent dit woord aan: "Djarak, paard. Misschien is dit woord overgenomen uit het Jav. of Mak., daar op geen der Tern. eilanden paarden voorkomen, behalve de enkelen, door Europeanen of Chineezen ingevoerd." (Bijdr. tot de kennis der residentie Teruate, blz. 263).

2. Gomōra. Dik koperdraad. Doch ook wat van koperdraad is gemakt, in dit geval haken. 


\section{Tābai.}

I d'or faro mānsĕrēn bjedi. Mānsērĕn bjedi, i baba. Insěrēn bjedi d'ōbo: "Tābai, wa pos in fa j'an." Rēsĕri Tābai i kōfēin : "Bape sarferba, ja sma sarferba!" Bin, i kōfein wer: "Rēsĕri ? Ko sma sārferba, ko bĕrariso ?" Tābai kōfein : "Ku fes kum kubena faro sarfer." I wan $\left({ }^{1}\right)$ bin ani, i pas kum, fa ma i duf, bin i mēwĕr, d'öbo: "Ja duf, ja mēwĕr, ku pōs in ba, ku bur be rum."

$\bar{A}$ nsōna insĕrēn kōfēin wer: "W'or bin ro ai běkwar kobeda (mes) $\left({ }^{2}\right)$ fa mānsĕrēn bedi i buk. Rēsĕri rās rās Tabai, i d'un arrta $\left({ }^{3}\right)$, roběan faro bin ani. I buk fa $\mathrm{i}$ bro, insĕrēn i kōeēin : "I bje kwar, Tabai, ko buk robĕan i bor kwar, wa fron nejan be ai bĕkwar ani, fa ko j'un mānsĕrēn kobedi faro binia. Wa fukĕn ai běkwar rēsĕri.

I fron nejan di suru. Nejan bjeda, i fanam, nejan faro insĕrēn bjedi kuker kawāsa i kwaim kaku.

Ōja rās, si mbrēin fa si jaker $\left(^{4}\right)$ romgunia faro binia, si kōfēin: "Tabai, wa ra pōn!" Bape Tabai i mēwěr, d'ōbo: "Ja sjuif, ja duf, krāf, i duf māngěnēm. Mgo j'un mānsĕrēn jedi faro binia, j'arĕm (5) imnis kwar." Tabai i mēwĕr - kawāsa si bur. Si bor bur swan, Tabai i d'ōpĕr fasau, i masi fasau i mbrein nejau bjeda ma i d'ek aruri.

Kawāsa, si mbrein fả awafuri, imam ( $\left.{ }^{6}\right)$ i fuken: "Aja ijonagē?( $\left.{ }^{7}\right)$

Tabai karĕm: Ijo Taba!" ( $\left.{ }^{8}\right)$

(I kofein : "I buk bin bur mānsĕrēn bjedi).

Kawāsa si kāndor, s’ōbo: "Ai d'ōbo: "Bin i buk Tabai. Imam i fukĕn wer. Tabai d'or wer: "Ijo Taba!"

Kawāsa si bur. Tabai i sabu fasau, i siber nejan kwaimba be rum. I barēk wer ro pāfēn, kawāsa s'ek rumia, s'ōbo: "Taba, ai i kōfēin : "Au, wa buk bin ōrja, mānsěrēn bedi awer. Tabai d'ōbo: "Aja womĕn bjeba $\left({ }^{9}\right)$, ja buk insĕrēu ba, mānsĕrēn jedi, i buk i. S'ōbo: "Roba, a i d'âp au kwar, wa masi, ko j'un au faro binia. Taba i marares i, i masi, i famamgor i, i rjīm $\left({ }^{10}\right)$ mani ro snumburaim, i sfu( $\left.{ }^{1}{ }^{1}\right)$ krāf bjeda, s'un i faro bin. Bape bin, i mām Taba, i mēwĕr, d'ōbo: "Womēn ja mēwẹr." Iriria, su sma i ba kaim. Taba, i sma ba, mānsĕrēu bjedi, i sma ba.

40. Tābai, die eene vrouw ging zoeken voor zijn meester, die nog klein was.

Zijne meesteres zeide: "Tābai, vang visch, opdat ik eet". En 
toen. zei Tābai: "Maar er is geen vischlijn, ik heb geen vischliju!" De vrouw zei weer: "Wat dan?" "Wat moeten we dan als we geen vischlijn hebben?"

Tābai zegt: "Dan binden we onze lichaamsharen tot een vischlijn!" Hij liet de vrouw hare lichaamsharen uittrekken, maar het deed pijn, daarom wilde de vrouw niet, ze zeide: "Lk heb pijn, ik wil niet, dan vangen we maar geen visch, dan gaan we naar huis".

$\mathrm{Nu}$ zegt de meesteres weer: "Vraag een vrouw aan onzen ouden boom (mes), opdat uw heer ze huwe. En toen brengt Tăbai iederen dag goederen en eten aan die vrouw. Toen hij (alles) weg gebracht had, zegt de meesteres: "'t Is goed, Tābai, wij hebben al veel eten gegeven, ga nu een weg wieden naar dien ouden boom, opdat we onzen heer tot zijne vrouw brengen. Vraag 't eerst aan den ouden boom."

Hij wiedde twee wegen. Eén weg, de zijne, was zeer kort, de weg voor zijne meesteres en haar volk zeer lang.

Daarna op den dag, dat zij zouden gaan om den jongen tot de vrouw te brengen, zeiden ze: "Tābai, ga vooruit!" Maar Tābai wilde niet, hij zei : "Ik ben koud, ik ben ziek, mijn lichaam doet te veel piju. Brengt gij mijnen heer tot de vrouw, ik heb genoeg bruidschat gebracht." Als Tābai blijft weigeren, gaan de menschen weg. $\mathrm{Zij}$ hebben nauwelijks 't strand verlaten of Tābai springt snel op en baadt zich gauw; dan loopt hij langs zijn weg en klimt in den top van den boom.

Het volk loopt ouder den boom, de priester vragt: "Aja ijonagēe"

Tābai antwoordt: "Ijo $\mathrm{Taba}$ !"

(Hij zei: dat hij de vrouw, die voor zijnen heer bestemd was trouwen moest).

Het volk was verbaasd; ze zeiden: "De boom zegt: "De vrouw trouwt met Tābai". De priester vraagt weer. Tābai roept weer: "Ijo Taba!"

Het volk gaat heen. Tābai daalt spoedig van den boom af en langs den korten weg terug naar huis. Hij ligt weer in de asch, als het volk in huis klimt. Ze zeggen: "Tābai, de boom zegt: "Gij moet die vrouw huwen, uw heer niet." Tābai zegt: "Ik ben een slechte slaaf, ik huw geen vrije vrouw, miju heer moet haar huwen." Ze zeggen: "Neen, de boom heeft jou genoemd, baadt je, we brengen je naar de vrouw!"

Tābai is trotsch, hij baadt en hij versiert zich; hij doet olie op zijn? haar en smeert zijn lichaam met olie. Daarna brengen ze hem naar de vrouw. 
Maar de vrouw, als ze Tabai ziet, weigert ze en zegt: "Een slaaf wil ik niet. Alzoo, kregen ze geen van beiden haar. Tabai kreeg haar niet en zijn heer kreeg haar ook niet.

A ant. l. Wan. Zenden, Sturen. Ook bevelen, gelasten, iets opdragen, iets laten doen.

2. Mes. Een hooge boom met boven den grond annvangende wortels, die als 't ware den boom stutten, door zijn voetpunt breeder te maken. De vruchtjes zijn. eetbaar, een harde schil en zacht, grijs vleesch om de kern. Smaak gelijk de ramboetan.

3. Als de verloving er door is, die door de wederzijdsche familieleden wordt in orde gebracht, dan begint het betalen van de bruidschat en de familie van den bruidegom laat ook visch en ander voedsel aau de bruid brengen. Gaat de verloving niet door, dan wordt dit voedsel tot den laatsten korrel in rekening gebracht bij de familie van het meisje.

4. Jakĕr rumgun. Den jongen tot zijne bruid brengen. Doorgaans wordt het meisje tot haren bruidegom gebracht. Gedurende de verloving, die jaren duren kan, mogen bruid en bruidegom elkaar niet zien. Is de huwelijksschat betaald, dan wordt het meisje meer of minder feestelijk naar het huis van den bruidegom gebracht.

5. Arēm. Het brengen van bruidschat gedurende den verlovingstijd.

6. Imam. Priester. De Papoesche éeredienst kent geen priesters. Uit het optreden van den priester in dit verhaal, blijkt de vreemde oorsprong er van; ook uit het vereeren van den boom.

7. Aja ijonagē. Liet ik onvertaald, daar ik de bet. er van niet begrijp. Waarschijnlijk geen Nuf.

8. Ijo Taba. De uitlegging van deze woorden volgt in den zin tusschen haakjes.

9. Bjeba. Niet goed, slecht. Kan echter ook beteekeneu "niet veel waard, gemeen (ordinair)" enz.

10. Rjìm. Gewoonlijk rmìmĕn, d.i. het haar met olie zalven.

11. Sfu. Een Papoe, die tot een feest opgaat, besmeert zich zooveel mogelijk met olie, zoodat de huid glimt.

\section{Rumgun, i mun kāpa. (')}

Imbĕkĕpu suru, su nei rumgun kpuri. Rās ōso kĕpuru snari, i d'om diaf, i sma kāpa. I rir kāpa ro ajĕr, fa i fan i. Rumgun kpuri bjedi i rama, i mām kāpa. I fauba, kapa kĕpuri bjedi, i kfo i. Kĕpuri i mām, si kfo kāpa, i msor nāba. I fukĕn mundiri 
i kfo kāpa bjedi. I mnāf rumgun kpuri bjedi i kfo i, i msor i. Su rama wer ro rum, i d'or rumgun kpuri bjedi, fa su pōs in. Kpuri i fara, ma rumgun i pōs in, wa $\mathrm{i}$ fo, bape insar i meōf in ba, isōf rumgun, i sma tarukĕn; in ōrnĕ insar i marisein.

$\mathrm{Su}$ rama wer ro rum, insar i fandur tarukĕn kor nakām be nora. $\left({ }^{2}\right)$ Rumgun i bur, i masi; i sibĕr wer, kpuri, i kōfēin : "W'ènēf ro nora $\left({ }^{2}\right)$ ōrnĕ." Rumgun i d'ènēf, kpuri i kuk i kukĕr tarukĕn borēk, ma i swarepĕn rumgun i mar kwar, i san i ro war.

War, i d'un i, snun suru, su suosna Sirije ma Mariai, su sma i, su frur i kukĕr ariaun. Su frur i, su frur i, isōf par tarukĕn borēk na miais kam.

Su frur munara $\left({ }^{3}\right)$ fa si disen wark $\left({ }^{4}\right)$ rumgun ani, rumgun i disĕn :

Apujo rōrō waria rwuri, Apujo apāngak ( ${ }^{5}$ ) kirje, Sirije mambĕnabje irja Mariaj mamběnabje irja.

41. De jongen, die een kāpa doodde.

Twee grootouders hadden een kleinzoon. Op een dag vindt de grootmoeder, terwijl ze aan 't onginnen is van een tuin, een kāpa. Ze zet de kāpa op de heg, om ze te voeren. Haar kleinzoon komt en ziet de $k a \bar{p}$ a. Niet wetende, dat het de $k \bar{a} p$ a van zijne grootmoeder is, schiet hij ze met een pijl. Als de grootmoeder ziet, dat men hare $k \bar{a}$ pa met een pijl heeft geschoten, is ze zeer boos. Ze vraagt, wie hare $k \bar{a} p a$ heeft geschoten. Als ze hoort, dat haar kleinzoon ze met een pijl heeft geschoten, is ze boos op hem.

Weer tehuis komende, roept ze haren kleinzoon, om te visschen.

De grootmoeder stuurt en de jongen vischt, de prauw vol, maar de oude vrouw wil de visch niet, totdat de jongen een zeeëgel vangt; met deze visch is de oude vrouw tevreden.

Weer tehuis komende, vergadert de oude vrouw alle graten van den zeeëgel tot een hoofdkussen. De jongen gaat heen om te baden. Als hij weer terug komt, zegt de oude vrouw: "Slaap op dit hoofdkussen." Als de jongen slaapt, prikt de oude vrouw hem met de stekels van den zeeëgel, tot zij denkt, dat de jongen dood is, dan werpt ze hem in het water.

Het water nam hem mee. Twee mannen, wier namen waren Sirijé en Mariai, vinden hem en behandelen hem met medicijn. Ze behandelen hem tot de wonden der zeeëgelstekels alle genezen ziju. 
Op het feest dat ze maken om dien jongen, te disen wark, zingt deze :

Grootmoeder aan den bovenloop der rivier,

Grootmoeder stak.

Sirije, dat is een goede man.

Mariai, dat is een goede man.

A ant. 1. Ka pa. Een buideldier, klein soort (buidelrat)?

2. Nora. Hoofdkussen. Tern. norah (De Cl. Res. Ternate, blz. 313.).

3. Munara. Al wat behoort tot een feest.

4. Disen wark. Zingen om den invoed van booze geesten te beletten.

5. A pangak. Geen gewoon Nuf., beteekent prikken, steken.

\section{Bōki ro rirwor.}

Radja ōso, i mām bōki, i kein ro rirwor. I marisein i ra be i, bape i fauba rariso. Rās ōso i mām rumgun kapirare, bōki srandi bjedi, i serf in ro der. Ma rub i siama, rumgun i d'or be bōki : "Wa buk awēk sarāk bani maro aja, fa j'ek, snaro tōbo ma wōngor nēri s’ark aja. Bōki i san awēk sarāk faro rumgun bjedi, i d'ek be i.

Rās wēsě, radja ani, i farari rumgun kapirare mgarēm bjeda, i d'or awēk sarāk. Bōki i swarepĕn : "Mgarĕm ro srar jedi ke ?" Bape radja ani i d'awēs mnis kaku, rjaui bōki i san awēk bjeda faro i. I d'ek kwar, ānsōna rumgun kapirare, i d'or awēk, bape radja i djaga ( ${ }^{1}$ ) awēk. Rumgun i kaněs, d'ōbo: "Tōbo kukĕr wōngor, nēri s'ark aja." Srar bjedi i swar i, bape radja i meōfba i d'ek.

Rub i sar kwar, ma war i sia ro rumgun mgasi rape, ansōna i d'or be kamari, snari $\left({ }^{2}\right)$ ro nanggi, d'ōbo: "Aja rumgun mubedi, aja radja, mu bĕtulung aja." I d'or rariria beri, i mam aimāndo běba bĕri; i kin aimāndo, ma ki i san aimāndo kukĕr rumgun kapirare be meōs ōso.

Ro meōs sıun kukĕr bin, su kēin kukĕr nēi sedi. Nei ōrnĕ i duk ( $\left.{ }^{3}\right)$ māsĕn, i mam aimāndo kukĕr rumgun ani. I d'un i be mansar, insar. I fiak (4) su d'ōbo: "Buk swa(5), ja sma rumgun ōso." Si fan rumgun kapirare, isōf i ba.

I be snungubor kwar, i fas wai ōso ro kajĕn kukĕr bäbār ma snunkaku, ma i d'or wer be snari, kamari bjedi.

Ma rās wēsĕ i rama, i mam wai, i fas kwar, djadi wai kaku kukĕr bārbār ma snunkaku. I kōfein faro bin ma snun, su fan i kwar, i serf mob bjeda, bape nēri i siber wer. 
Rāso srandi bjedi, radja ani i bụk i kwar, i d'orĕs kukĕr rumgun bjedi ro swan; ma rumgun bjedi i kanĕs, d'ōbo : "Wa kaněs awer, ja mām wai, meri bedi ke, aimāndo i d'un i, neri i rama wer. Swari bjedi i kofēin: "Ōrnĕ kaku?" "Mboi", bin i kōfēin, "ja mām i d'orĕs ro wai fandu."

Ma snungúbor i d'orĕs ro wai, i d'an berěn, ma berěn i rik maroba, piupĕr $\left({ }^{6}\right)$ munda. Ma i ra fanām srandi, rĕfiori su, i d'uf ma si kam, si ro. Ma i siběr wer be meōs ani.

\section{De prinses op het koralrif.}

Een koning ziet eene prinses, die verblijf houdt op een koraalrif. Hij wil tot haar gaan, maar hij weet niet, hoe? Op een dag ziet hij een kleinen jongen, den broer van de prinses, visch zoeken bij eb. En als de vloed komt, roept de jongen tot de prinses: "Geef mij die zilveren ladder van je, om op te klimmen, want haaien en krokodillen zullen mij bijten." De prinses werpt den zilvereu ladder aan haren broer toe, die dan tot haar opklimt.

Op een anderen dag, doet die koning de stem van den kleinen jongen na, roepende om den zilveren ladder. De prinses denkt: "Is dat de stem van mijn broer?" Maar die koning spreekt zeer juist na, daarom werpt ze haren ladder tot hem. Als hij is opgeklommen, vraagt die kleine jongen den ladder, maar de koning hield den ladder tegen. De jongen weent, zeggende: "Haaien en krokodillen zullen mij bijten." Zijne zuster heeft medelijden met hem, maar de koning wil niet, dat hij opklimt.

De vloed dringt het land in en het water is reeds tot de oogen van den knaap, nu roept hij tot zijnen vader en moeder in den hemel, zeggende: "Ik uw beider zoon, ik ben de koning, helpt mij!" Als hij aldus geroepen heeft, ziet hij dadelijk een zeer groot drijfhout; hij grijpt dat drijfhout vast en de stroom werpt het drijf hout met den kleinen jongen op een eiland.

$\mathrm{Op}$ het eiland houden een man en vrouw verblijf met hunne dochter. Dit meisje zeewater halende, ziet het drijfhout met dieu jongen. Ze brengt hem bij den grijsaard en de oude vrouw.

Ze fiak hen beiden, zeggende: "Bukswa, ik heb een jongen."

Ze voeden den kleinen jongen tot hij groot is.

Als hij jongeling is geworden teekent hij een prauw in het zand met vlaggen en menschen en hij roept weer tot zijn moeder en vader. En den anderen dag, als hij komt, om de prauw te zieu, die hij geteekend heeft, is deze een echte prauw geworden met vlaggen 
en menschen. Hij zegt tot de vrouw en tot den man, die hem gevoed hebben, dat hij zijne geboorteplaats gaat zien, maar hij zal terugkomen.

Op zekeren dag staat zijne zuster, die met dien koning was gehuwd, met haar kind aan het strand; als haar kind huilt, zegt ze: "Huil niet, ik zie een prauw, 't is misschien je oom, het drijfhout heeft hem meegenomen, hij zal weer komen." Haar man zegt: "Is dat zoo?" "Ja," zegt de vrouw, "ik zie hem in het midden van de prauw staan." En de jongeling staat in de prauw, hij eet pinang en de pinang is niet rood, ze is slechts wit. En als hij dicht bij zijne zuster en zijnen zwager komt, blaast hij en ze gaan allen verloren. Daarop keert hij weer terug naar dat eiland.

A a nt. 1. Djaga. Mal. oppassen. Krijgt in het Nuf. de beteekenis van tegenhouden, beletten, verhinderen.

2. De Nufooren houden de geesten der afgestorvenen voor machtiger dan die der levendeu. Daarom vreezen ze den toorn dier

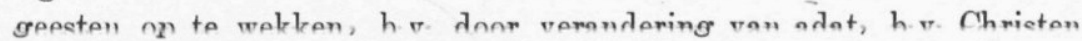
worden. Een gebed echter tot die geesten, z. a. van dezen knaap, zijn de Nuf. niet gewend.

3. I) u k. Water putten, ook scheppen uit een rivier of uit de zee.

4. Fiak liet ik onvertaald. J. L. Van Hasselt.- Woordenboek. Noef.-Holl. geeft op blz. 12. "schelden, bepaaldelijk gemeene, zedelooze woorden gebruiken." Er bestaat voor een schelden een woord kōriajĕ̀r. Dat is ons gewone uitjouwen, uitschelden. Daar mag een Papoe kwaad om worden, er wordt doorgaans geen boete voor geëischt. Fiak is een trap erger. Dan wordt bijna altijd gedoeld op geslachtsgemeenschap. Men gebruikt die uitdrukkingen bij zaken, die in 't geheel geen verband houden met een dergelijk scheldwoord. Degene, die zoo gescholden wordt, heeft recht eene boete te eischen. De uitdrukking, die hier volgt is echter een zóó algemeen verbreid stopwoord, dat kinderen 't heel gewoon tot de ouders zeggen.

5. Bukswa. Is niet goed te vertalen. Stopwoord, dat lett. beteekent: Houd geslachtsgemeenschap met je man of je vrouw."

6. Wat het beduidt, dat de pinang niet rood, maar wit is, weet ik niet.

43. Nei i d'an berĕn kamari, snari.

Bin kukĕr swari, kukĕr nei bjidi s'enef ro rum. Isna snun ma 
bin, su perĕm wai. Su j'âfĕn berĕn ro nokēn, su mbrein. Nei i d'an berĕn.

Snun ma bin, su bur be rum wer, su mam ōso i d'an berěn seda. Su fukĕn nei, bape nei d'ōbo: i fauba.

Isna wer, bin ma snun; su j'āfēn berĕn ro nōhēn, su bur fa su perem wa seda. Māndira wer, snun ma bin, su bur be rum wer, su mam ōso, i d'an berěn. Su fukĕn faro nei, bape nei i kōfēin: i fauba.

Rās běkiōr wer, isna, snun ma bin, su j'āfĕn beren ro nōkēn, su bur fa su perĕm wa. Mandira, su bur be rum, su mām, ōso i d'an berĕn seda. Su fukĕn nei, bape i kōfēin: i fauba.

Snari, i msor nei, i kōfein faro i: "Wa bur be Ninbōmbrawi ro Sorĕndiweri $\left({ }^{1}\right)$, i buk au." Nei i msor, i kēruk āmburēs $\left({ }^{2}\right)$, i frur pāngir ma $\mathrm{i}$ kein ro āmburēs dōri, ma i san mangundi ro māsĕn. Ki i d'un i, suari i d'or mānsar, si māsi: "Mgo kin i ba?" Bape mānsar si kōfein. "Amin běsōrja!" Snari i d'or be snun, si fararu: "Mgo kin i ba?" Si kōfēin: "Amin běsōrja!" Snari i d'or snun, si fārbuk robaim: "Mgo kin i be ?" Si kōfēin; Amin bĕsōrja !" Snari i d'or wer snungubor: "Mgo kin i ba?" Si kakō, si kōfēin: "Ko kin, bape amin běsōrja!" Snari i d'or wer be rumgun, si masi: "Mgo kin i ba?" Rumgun, si kōfēin: "Ko kin, bape amin i běsōrja!" Snari i d'or wer be romawa kapirare, si masi : "Mgo kiu i ba?" Si kōfēin: "Ko kin, bape amin besōrja!"

Ma ki, i d'un amin kukĕr inei be sorĕn, isōf amin i d'er ro swapōr ōso, ma Ninbombrawi ro Sorĕndiweri i d'or i ōrwa, i d'un i ma i buk i.

Taun $\left({ }^{3}\right)$ suru Nimbombrawi i bur kukĕr swari be māmbāniori ma imbaniori. Ma i fukĕn swari bjedi i bor bur snari, kamari, snaro? Snari i kōfēin, snaro snari i d'awĕs i kukĕr berĕn.

Ma Niubombrawi i kēin kukĕr swariswari ro rum māmbāniori, imbāniori bjedi.

43. Het meisje, dat de pinang van vader en moeder at.

In een huis wonen vrouw, man en ééne dochter. Als het licht wordt, gaan man en vrouw weg, om een prauw te hakken. Zij doen de pinang in een zak en ze gaan heen. Het meisje at de pinang op.

Als de man en de vrouw weer naar huis gaan, zien ze dat iemand hun pinang opgegeten heeft. Ze vragen het meisje, maar het meisje zegt, dat ze er niets van weet. 
Als het weer licht wordt, doen vrouw en man weer pinang in een zak en gaan heen om hunne prauw te hakken. Als het weer avond is, komen ze weer tehuis en ze zien, dat iemand de pinang heeft opgegeten. Zij vragen aan het meisje, maar het meisje zegt, dat ze er niets van weet.

Als de derde dag aanbreekt, doen de man en vrouw weer hun pinang in een zak en gaan heen om hunne prauw te hakken. 's Avonds, tehuis komende, zien ze weer, dat iemand hunne pinang opgegeten heeft. Ze vragen er naar aan het meisje, maar dit zegt, dat ze er niets van weet.

De moeder is boos op het meisje, en zegt tot haar: "Ga naar Ninbōmbrawi van Sorĕndiweri, huw met hem". Het meisje is boos, ze hakt een amburēs af en makt er een gat in, ze gaat in de $\bar{a} \mathrm{mburēs}$ zitten, en ze werpt zich zelve in zee. Als de stroom haar meêneemt, roept de moeder tot de grijsaards, die aan het baden zijn : "Houdt ge haar niet vast?" Maar de grijsaards zeggen: "De bamboe is te glad!" De moeder roept tot de mannen van middelbaren leeftijd: "Houdt ge haar niet vast?" Ze zeggen: "De bamboe is te glad!" De moeder roept tot de mannen, die nog niet getrouwd zijn: "Houdt ge haar niet vast?" Ze zeggen: "We zouden wel vasthouden, maar de bamboe is te glad!" De moeder roept tot de jongelingen : "Houdt ge haar niet vast?" De jongelingen antwoorden : "We zouden haar wel vasthouden, maar de bamboe is te glad!" De moeder roept tot de jongens, die aan het baden zijn: "Houdt ge haar niet vast?" De jongens zeggen: "We zouden wel vasthouden, maar de bamboe is te glad!" De moeder roept tot de kleine jongens, die badeu: "Houdt ge haar niet vast? Ze zeggen: We zouden wel vasthouden, maar de bamboe is te glad!"

En de stroom neemt de bamboe met het meisje meê naar den oceaan, totdat de bamboe strandt aan een kaap en Ninbombrawi van Sorĕndiweri vindt haar daar; deze neemt haar mee en trouwt haar.

Twee jaren later gaat Ninbōmbrawi met zijne vrouw naar zijuen schoonvader en zijne schoonmoeder. En hij vraagt, waarom zijne vrouw van hare moeder en haren vader is weggegaan. De moeder zegt: "Omdat ze haar berispt heeft, wegens de pinang."

En Ninbōmbrawi, hij woont met zijne vrouw in het huis van zijnen schoonvader en zijne schoonmoeder.

Aant. 1. Sorĕndiweri. Deze naam komt ook voor in $\mathrm{N}^{0} 37$, 
de fabel van Inkonkuburi. S or ĕn is oceaan, weri zegt men voor den mond, het einde eener rivier. Sorĕndiweri zou dan zijn: "Waar de oceaan eindigt $"$.

2. Amburēs. Liet ik onvertaald. 't Is eeu bamboesoort van middelmatige dikte.

3. Ta un. Jaar. Uit het Mal. overgenomen. De Nuf. hecht er echter niet het begrip aan van 12 maanden. Heel dikwijls van één moeson.

\section{Snun, i d'om diāf ba.}

Ka wāsa kām s'om diāf. Snun ōser, i d'ak d'om diāf maroba; i d'ènĕf munda. Rās ōso bin i kōfein faro i: "W'om diāf ba, nēri ku biser!" Suun i kōfēin: "Wa frur robĕan, mèsĕr arwo prim nēri ja ra!" Ma arwo snun i d'un sumber ma urĕn kukĕr robĕan bin i fnap kwar. Bape i mbrein wauerīk be diāf. I rama ro sup kwar, i d'an roběan bjeda ma i d'ènĕf wer. Mandira, i bur be rum kukĕr kawāsa wēsĕ, s'om diāf kwar, bin i fukĕn : "Diāf ibro fasau?" Snuu, i kōfēin: "Alboi, ibro fasau!" Ma rās bĕsuru, ras bĕkiōr rariria munda. Rās bĕonēm, snun i bur wer, bin i jom i. Bin, i mām, kawāsa wēse diāf seda ibro rape. Bin i mām mob, swari bjedi i d'om i mbron munda, ma snun mangundi i d'ènĕf. Bin, i msor, i bur be rum. Snun i rama ro rum wer, bin, i fukĕn wer: "Diāf ibro kwar?" Snun, i srer wer, d'ōbo: "Ibro kwar, korikko ko ker!"

Arwo snun, i d'or robĕan bjeda wer, bin i d'un urën, ma i kapu. ro dōri, urēn i fo. I bor urēn kukĕr undaim, i kōfēin faro snun: "Robĕan beda is ōrnĕ!" Suun, i kin sumber, i d'un urĕn ma i bur. Snun i rama ro mob bijani, i bas urēn, ma kapu i mbrām. I snarĕm, i kōfēin : "Mundiri i kapu ro diāf jeda?" I d'un urĕn wer, i kēin ro mob wēsĕ. $I$ bas uren wer i mbrām wer; i d'un urĕn wer, i kēin ro mob ōso wēse wer, i mbrām wer. Bape snun i kōfēin: "Bje kwar, i mbrām wauerìk, ja kēin munda. I bas urĕn, i marisēin i d'an, bape rwasi i fo kukĕr kapu. I suēri sām, i wef urĕn, i kin sumber; i frar be rum. Kawāsa, si mām i, si kōfēin: "Rosēi i sia, wa frar so ?" Bape i d'awĕs faro ōso maroba, i frar munda, i kin sumber be bo.

Bin, i mām suun bjedi i rama, i mkak naba, i swarepĕn : "Ras inè, ja mar; nēri i perĕm aja!" I ra be mob s'eněf, i sjob sre be bo. Snun i serf bin, i sma i rariria, i san sumber bjeda, msor bjeda ibro bĕri $-i$ forepĕn bin, ma su bĕbati wer. 
44. De man, die geen tuin ontginde.

Alle menschen ontginnen tuinen. Eén man ontginde echter geen tuin, hij sliep maar. Op zekeren dag zegt zijne vrouw tot hem: "Als gij geen tuin ontgint, dan zullen we honger lijden!" De man zeide: "Maak eten klaar, morgen ochtend vroeg ga ik!" En 's morgeus neemt de man zijn hakmes en de pan met eten, dat de vrouw heeft gekookt. Maar hij ging zoo maar naar den tuin. Als hij in het bosch komt, eet hij zijn eten op en dan gaat hij weer slapen. 's Avonds gaat hij naar huis met het andere volk, die wel tuinen outgind hebben, en dan vraagt de vrouw: "Is de tuin gauw klaar?" De mau zegt: "Zeker, gauw klaar!" En den tweedeu dag, den derden dag, gaat hij maar zoo door. Den zesden dag, als de man weer heen gegaan is, volgt de vrouw hem. De vrouw ziet de tuinen der andere menschen reeds gereed, maar ze ziet, dat de plaats, waar haar man ontgint, een wildernis is en dat de man zelf slaapt. De vrouw is boos en ze gaat naar huis.

Als de man weer thais komt, vraagt de vrouw: nIs de tuin gereed P" De man liegt weer en zegt: "'t Is gereed, spoedig kunnen we gaan plauten!"

Des morgens vraagt de man zijn eten weer en de vrouw brengt de pan, maar ze doet er hare behoeften in, de pan vol. Ze bedekt de pan met bladeren en zegt tot den man: "Hier is je eten!" De man grijpt zijn hakmes, haalt de pan en vertrekt. Als de man komt op de voor hem bestemde plek, maakt hij de pan open en de st... stinkt. Dit ruikende, zegt hij: "Wie heeft er zijne behoefte gedaan in mijn tuin?" Hij neemt de pan weer en gaat op een andere plek zitten. Nu maakt hij de pan weer open - daar stinkt het weer; hij neemt de pan weer op en gaat weer op een andere plek, daar stinkt het weer. Maar de man zegt: "'t Is goed, het stinke maar ik blijf maar zitten." Hij maakt de pan open, hij wil eten, maar de hand is vol st... Hij wordt boos en verbrijzelt de pan; hij grijpt zijn hakmes en loopt hard naar huis. Het volk, dat hem ziet, zegt: "Wat is er, dat gij zoo hard loopt?" Maar hij spreekt tot niet één, hij loopt maar hard, hij houdt 't hakmes naar boven.

De vrouw, hareu man ziende, vreest zeer, ze denkt: "Heden sterf ik; hij zal me 't hoofd afslaan!" Ze gaat naar de plaats, waar ze slapen en trekt de sarong op. De man zoekt de vrouw en haar aldus vindende, werpt hij zijn hakmes weg; zijn boosheid is dadelijk voorbij, hij omhelst de vrouw en ze worden weer vrienden. 


\section{Sumbersawai.}

Sumbersawai, i buk bin samfur. Bin ōso, i sma rumgun; bin siw, si sma rumgunbaim. $\left({ }^{\mathrm{I}}\right)$

Sumbersawai, i frur wa bjeda, insa i sjom radja Kōraré. I bur, i wan kamari bjedi, i mansar kwar, i djaga bin bjesi. Sumbersawai i bur, mānsar i kar $\left({ }^{2}\right)$ bareām, i fukĕn bin ōso i so i.

Si kar bareām kwar, si riāmĕs $\left({ }^{3}\right)$ mansowe, i wan bin, i d'āfĕn $\left({ }^{4}\right)$ bareām ro undaim. Bin, i kunēm, insa i pāngum bareām ro undaim, mansar i perēm rwuri bjeda. I san bākĕn, ma rwuri i d'un. I rama ro rum, i san rwuri ro rōnan ro rumraundi, ma $\mathrm{i}$ buk bareām faro bin si. Si mām bareām, i rik, si fukĕn : "Bareām, i rik rariso ?" Mānsar i karēm: "Bareām babo, riani i rik (5), mg'an wauerìk !" Ma si fukĕn : "Bin ani i so ?" I kōfēin : "I kein ro ser $\left({ }^{6}\right)$, wam i mararer ram, i marisēin i d'ènēf ōrwa."

Isna wer, mānsar i bores wer, i d'un bin bĕsuru wer. I kar bareām, su riaměs mansowe, i wan bin, i pangum bareām. Bin, i pāngum bareām, mānsar i perēm rwuri bjeda wer. I sau bākĕn, ma i d'un rwuri. I rama ro rum, i san rwuri ro rōnan, ma i buk bareām be bin si. Bin, si mām bareām, i rik, si fukĕn : "Bareām babo, riani i rik!" Si fukĕn : "Bin, i d'un ani, i so ?" Mānsar, i kōfēin : "I kēin ro ser, wam i mararer ram, i marisēin i d'ènēf ōrwa!"

Iriria, i mun bin war. I bur kukĕr bin bĕsiw. Bin i kein kukĕr rumgun, i kein mauĕr ro rum, i snarĕm ro bĕmbrām. I serf, i mām bin bĕmar rwuběkor, si pōkēm ro rōnan. I kin rumgun bjedi, i bur, ma i d'ek kris ōso, i waf Sumbersawai. I mām wa bjeda ro mob běkwaim. Wa i fanām, fanām wer, bin, i kein ra airuri, i disĕn: "Sumbersawai, kmami i min, i d'anbĕrano; rāngĕmāk!" ( $\left.{ }^{7}\right)$

Kawāsa ro wa, si mnāf ōso i disěu, i d'āp Sumbersawai snōri bjedi, si borĕs be sup, ma si mnāf bin i disěn : "Sumbersawai, kmami i min, i d'anbĕrano; rāngĕmāk !" Si serf bin ōrně, si mām i ba. Si mām war ro knāmafuri. Ōso, i srōr $\left({ }^{8}\right)$, i mam bin ani niniman bjeda ro war dōri. Si kōfēin : "Bin ani i sia ro war dōri!" S'arōn, s'aron, fa si serf i, bape si sma i ba. Si mām be bo, si mān bin kukĕr rumgun ro knāmruri. S'un i be sōp, i faja nakām faro Subersawai.

Sumbersawai, i msor. Bape i ma kawāsa bjeda, si famāmgor $\left({ }^{9}\right)$ si, ma si disĕn. Iriria si rama be rum. Sumbersawai $i$ fukĕn kamari : "Bin kām s'isia ro ? S'un sāmbako ba, s'un berěn $\left({ }^{1{ }^{\prime}}\right)$ ba." Māısar, i kōfein : "Si mbrĕin be sup, knîko, si rama wer." 
Sumbersawai, i mkak, i perĕm kamari, nēri rik bjeda i min i. (' ') Bape i kofēin faro mānsar, i barek ro swan, ma si frur mānsar be batār. $\left({ }^{1}{ }^{2}\right)$

Ma mānsar i mar rariria.

45. Sumbersawai.

Sumbersawai had tien vrouwen gehuwd. Eén vrouw had een kind, negen vrouwen hadden nog geen kind.

Sumbersawai maakt zijne prauw in orde, om te gaan hulde brengen aan den sultan van Tidore.

Heengaande, draagt hij aan zijnen vader, die reeds een grijsaard was, op zijne vrouwen te bewaken. Als Sumbersawai is heen gegaan, gat de vader sago hakken en hij vragt eene der vrouwen hem te volgen.

Als ze sago hebben gehakt en de vezelen uitgezift hebben, beveelt hij de vrouw, het sagomeel in de bladeren te pakken.

Als de vrouw bukt, om de sago in te pakken, dan hakt de grijsaard haar 't hoofd af. Hij werpt het lichaam weg en het hoofd neemt hij mee. Als hij te huis komt, werpt hij het hoofd de rouan in het voorhuis, en hij geeft de sago aan de vrouwen. Als zij zien, dat de sago rood is, vragen ze: "Hoe komt de sago zoo rood?" De grijsaard antwoordt: "'t Is versche sago, daarom is ze rood! eet maar!" Eu op hare vraag: "Waar is die vrouw?" antwoordt hij : "Ze blijft in de ser, de wind beweegt de bladeren, ze wil daar blijven slapen."

Als 't weer licht wordt, roeit de grijsaard weer weg en hij neemt de tweede vrouw mee. Als hij de sago heeft gehakt, ziften ze de vezelen uit en dan beveelt hij de vrouw de sago in bladeren te pakken. Als de vrouw de sago inpakt, hakt de grijsaard ook haar 't hoofd af. Hij werpt het lichaam weg en hij neemt het hoofd mee. Als hij thuis komt, werpt hij het hoofd in de ronan en hij geeft sago aan de vronweu. De vrouwen, de sago rood ziende, vragen: "Hoe komt de sago zoo rood?" De man zegt: "t Is nieuwe sago, daarom is ze rood!" Als ze vragen naar de vrouw, die hij meegenomen heeft, dan antwoord de grijsaard: "Ze blijft in de ser, de wind beweegt de bladeren, ze wil daar slapen!"

Zoo doodt hij acht vrouwen. Hij gaat met de negende weg. De vrouw, die het kind heeft, is alleen thuis. Ze ruikt, dat er iets stinkt. Als ze zoekt, ziet ze de doodshoofden der doode vrouwen, die rottende zijn in de rouan. Zij grijpt haar kind en gat weg; ze klimt in 
een kriesboom, en wacht op Sumbersawai. Ze ziet zijne prauw in de verte. De prauw nadert, meer en meer. Nu zingt de vrouw, die in den boomtop zit deze woorden: "Sumbersawai, kmami i min, i d' anbĕrano, rāngĕmāk!"

Het volk, dat in de prauw is, hoort iemand zingen, die den naam van Sumbersawai noemt, daarom roeien ze naar land; en ze hooren de vrouw zingen: "Sumbersawai, kmami i min, i d' anbĕrauo, rāng ĕmāk!" Ze gaan deze vrouw zoeken, maar zien haar niet. Als ze water onder den boom zien, bukt een zich, om te drinken, en deze ziet haar schim in het water. Nu zeggen ze: "Die vrouw is in het water!" Ze duiken, ze duiken, om haar te zoeken maar ze vinden haar niet. Als ze naar boven zien, zien ze de vrouw met het kind in den top van den boom. Ze brengen haar naar beneden en dan vertelt ze alles aan Sumbersawai.

Sumbersawai wordt boos. Maar hij en zijn volk versieren zich, en ze zingen. Zoo komen ze thuis. Sumbersawai vraagt aau zijneu vader: "Waar zijn alle vrouwen? Ze brengen geen tabak, ze brengen geen pinang." De grijsaard zegt: "Ze zijn naar het bosch, dadelijk komen zij weer."

Sumbersawai vreest, dat als hij zijnen vader het hoofd afslaat, zijn bloed op hem zal gewroken worden. Maar hij beveelt den grijsaard op het strand te gaan liggen en zij maakten den ouden tot batar.

En zoo sterft de oude man.

Aant. 1. Rumgun. Zoon, jongen, doch ook kind in 't algemeen.

2. Kar bareām. Het omhouwen der sagoboomen, doch ook al wat met het sago winnen samenhangt.

3. Ri am ěs mansowe. Als de boomen geveld zijn, wordt de sago uit den stam geklopt. Er zijn echter nog vezelen tusschen het merg. Deze worden er uit gezeefd. De vezelen heeten mansowe. Het zeven, ri a mĕs.

4. $\bar{A} f \mathrm{e} n$. Als de sago gezeefd en gewasschen is, wordt ze ter verdere expedieering in bladeren gepakt.

5. Rik. Rood. Er zijn verschillende soorten van sago. De een is blanker dan de andere. De Nufooren onderscheiden de volgende soorten bareām (sagomeel, ook sagoboom).

Bareām Bĕfor. Deze soort levert het meeste meel. Kenteeken: jonge bladeren rood.

7• Volgr. VII. 
B. Kré, levert minder meel. Jonge bladeren geel, dorens aan stam en bladeren, niet lang.

B. Trua, levert weer minder dan kré, scherpe, roode doornen.

B. B ̌̆jas, levert weer minder. Geen doornen.

B. A pimbu, levert weinig meel. Stam en bladstengels dicht met doornen bezet. Merg rood.

B. Bon. Komt alleen op de bergen voor. De stam is laag en zeer dik. Levert veel meel.

6. Ser. Het sagobosch. Sago groeit in moerassige bodem.

7. De uitdrukking liet ik onvertaald. Kmami is: uw vader; i min hij treft. Min wisselt echter af met $\mathrm{mun}$, gelijk bin met Meosw. wun (vrouw) en manauur met Brakuz mananir (hoofd); d'aubĕrano ken ik niet, of het moest gescheiden zijn - a n is eten en ran op Roon en Meos War, sago, doch dan begrijp ik nog de iuvoeging van bĕ niet; rāng ĕm $\bar{a} k$ is het z.n.w. vlieg en duidt, z. a. ik mij de verklaring herinner op de vliegen, die om de rottende doodshoofden gonsden.

8. Srōr. Het bukken om als eeu hond water te drinken.

9. $\mathrm{Si}$ famamgor si. 't Is de gewoonte van hen, die eenigen tijd uit roeien zijn geweest, om kort voor de plaats humner bestemming aan land te gaan, zich daar te baden, te versieren met bladeren en bloemen, met olie in te wrijven, om dan zingend "fix und fertig" bij de humnen te verschijnen. Is er echter eenig ongeval geweest op de reis of heeft men bericht ontvangen, dat er te huis wat niet in den haak is, dau komt de prauw stil binneu. De roeiers roeien langzaam, alsof ze aarzelen binnen te komen.

10. Zie aant. 4 van $\mathrm{N}^{\circ} .20$.

11. De Papoea's zijn zeer bevreesd 't bloed te vergieten van hunne eigene verwanten. Ook plaatsen, waar bloed van familieleden is gevloeid, worden zorgvuldig vermeden en men eet tot in het derde en vierde geslacht de voortbrengselen niet van een streek, waar bloed van een der hunuen heeft gevloeid. $D^{r}$. Adriani zegt, dat men inzonderheid bevreesd is het bloed te vergieten van hen, die bloedschande bedreven.

12. Batar. Om de prauwen makkelijk op te trekken, legt men op het strand ronde houten, waarover heen de prauw getrokken wordt. Deze houien noemt men bater.

46. Mānoin (1).

Romgun suru, su j'ènēf ro rum srām $\left({ }^{4}\right)$. Rēsĕri rōb su serf in. 
Su serf in, su sma in kwar rōb fandu kaku. Rōb fandu kaku, su bur be rum srām ani.

Mānoin i sia kwar, i d'ek ro arĕn.

Māndira, su serf in, su kōfēin faro kamari, i bĕmāusar, su kōfēin: "Rōb, nu serf in, w'ènēf rum inè, ko fauba, suun ōso i rama ke. Ōrja, i d'ek rum srām, manoin i d'ek bĕpōn kwar, i d'ajan āběruk $\left({ }^{3}\right)$. Mansar i pōkba i d'ek, i d'ènēf ro rum raundi mangundi bjeda, i mbrēin be rum sramia ba.

Mānoin i frur manguudi imuis kamari mānsar; i d'ènēf ro romgun jar subeda, i kun far $\left(^{+}\right)$subeda. Su rama, su j'un in, su ban mānsar ani, su j'ōbo: "Mami, wa kun in, fa w'an!" Mauoin māusar, i kōfēin: "I bje, mu kun bĕpōn, mu j'ènēf, j'ek be bo, fa ja kun jedi fa j'an. Su kun in subesi, su j'an bĕpōn, su j'ènēf.

Ānsōna mānoin mānsar ani i d'orĕs, i kun in bjedi fa i d'an ibro, ānsōna i min romgun di suru. I mun su kwar, i farowe bĕba sāmfar, amo, kak, sarāk $\left({ }^{5}\right)$, mar bjeda faro běkanìkia. Běkanîkia sāmfar, kak, amo, sarāk, mar bjediı faro běbaia. Rēsĕri su j’ènēf isōf isua.

Ārwo su j’ibĕr su, běba i d'ibĕr i bĕpōu. I mām, d'ōbo: "Mundiri bĕjun amo, kak, sāmfar, saräk, mar jeda fa i buk pake bēknìk jedi? Bĕkanìk i d'ibĕr i, d’ōbo: Kaku, beda, aja bĕpake; jeda, au roa bĕpake". Mānsar ani, su fukĕn: "Mami, au w'ènēf ro rum, nu buk in faro au, au wa farowe famaingor nubena?" Bape ka'mari subedi frauba, i d'ènēf ro rum srām ba.

Ānsōna, su swarepěn: "Ko sma mānoin rape, rōb i d'ek, i farowe famāmgor nubena kām.

Āusōna, su kōfēinbadir kam faro kamari, suari: "Nu buk in, manoin i min nu, i farowe famāngor nubena."

Isōf ārkōk rape, imuis su j'inēm swan, rwuri piarek, su mar rape.

Ōrja su fāmfabĕr; bĕba d'ôbo: "Au, wa mar bĕpōn, aja kēin rēsĕri." Bĕkanîkia i kōfēin: "Roba, au wa mar bĕpōn, ja bĕdjaga kubir beda, ja mun manoin, rēsěri ja mar.

Bĕba, i mar bĕpōn. S’erak i - bĕknìk i kōfēin: "Mgo san saprōp ro bo awer, mgo rir sradaim munda, fa j'ènēf ro bo; ja mar, ja fnōk běba jedi.

S'un bĕba be kubir, si bor sradaim ro kubiria bori. Maudira, běkanîk i sasiar, i sabu ro kubir bĕba bjedi. I sabu, i kēin ro běba bjedi bori, knìko manoin i sia ma. I rama, i fau bĕkenĕmia ba, i swarepĕn bĕmaria munda. I pāukaker sradaim, fa i mām ro kubir dōri, i d'aumēs ro wesi, bĕmar i karēmba, i d'aumēs ro rwuri, běkenēmia i karěm āngar, i srer $i$. 
Bĕkanìk i d'ènēf kukĕr sumber. Manoin ani i d'aumēs, běkanîk i for i, i kēruk mānoin rwuri, mānoin i mar, bĕkanìk i d'akmar; s'erak kaim.

\section{Mānoin.}

Twee jongens sliepen in een $\mathrm{rum}$ srām. Op een nacht gingen zij visschen. Te middernacht gelukt het hun, wat visch te bemachtigen en toen gingen ze naar die rum srām.

De mānoin was er al, hij was op den zolder geklommen.

Toen ze 's avonds waren gaan visschen, hadden ze gezegd tot hunnen vader, die een grijsaard was: "Van nacht gaan we visschen, slaap in dit huis, want misschien zou iemand kunnen komen." Daarop was hij in de rum-srām geklommen. De mānoin, die eerst ingeklommen was, schudde echter de ābĕruk. De grijsaard kon er niet inklimmen en ging slapen in zijn eigen voorhuis, en ging niet naar de rum sram.

De mānoin maakte zich gelijk aan den ouden vader, hij ging slapen op de mat der beide jongens en hij stak hun vuur aan. Als zij beiden komen, medebrengende hunne visch, wekken zij dien grijsaard, zeggende: "Vader, rooster de visch, om te eten!" De mānoin (grijsaard), zegt: "'t Is goed, gaat gij eerst roosteren, en als gij slaapt zal ik opstaan, om de mijne te roosteren en te eten." Als ze hun visch hebben geroosterd en gegeten, gaan ze slapen.

$\mathrm{Nu}$ staat die $\mathrm{ma} n$ oin-grijsaard op, hij roostert zijn visch om op te eten en dan slaat (treft) hij beide jongens. Als hij hen geslagen (getroffen) (gedood) heeft, verwisselt hij de armbanden van den oudste eu zijn schaamgordel met die van den jongere. De armbanden van den jongere en zijn schaamgordel verwisselt hij met die van den oudste. En toen sliepen zij tot den morgen.

Des morgens worden ze wakker. De oudste wordt het eerst wakker. Hij zegt: "Wie heeft mijne armbanden weggehaald en mijn schaamgordel, om mijn jongeren broeder aan te doen?" De jongere wordt wakker en zegt: "t t Is zoo, de uwe heb ik aan; de mijne hebt gij aan". Zij vragen aan den ouden man: "Vader, gij hebt in huis geslapen en wij hebben visch aan u gegeven, hebt gij onze sieraden verwisseld ?"

Maar hun vader weet het niet, hij sliep niet in de rum srām.

$\mathrm{Nu}$ denken ze: "De mānoin heeft ons reeds in zijne macht, in den nacht is hij ingeklommen en heeft onze sieraden verwisseld."

$\mathrm{Nu}$ zeggen ze alles aan hun vader en moeder: "Wij hebben visch 
gegeven aan een mānoin en toen heeft hij ous getroffen en onze sieraden verwisseld."

Tot den middag gevoelen ze zich duizelig of ze sagoweer hebben gedronken, ze waren al stervende.

Daarop twistten ze; de oudste zegt: "Sterft gij nu eerst, dan blijf ik nog". De jongere zegt: "Neen, sterft gij eerst, dan zal ik op uw graf passen en als ik den mānoin heb gedood, dan sterf ik".

De oudste sterft eerst. Als ze hem begraven zegt de jongere: "Werpt geen aarde er op, legt slechts klapperbladeren er op, dat ik er op slaap; als ik sterf, dan voeg ik mij bij mijnen ouderen broeder."

Als ze den oudste naar het graf brengen, leggen ze klapperbladeren boven op het graf. 's Avonds gaat de jongere naar buiten en daalt in het graf van zijnen ouderen broeder. Hij daalt neer en legt zich boven op zijuen ouderen broeder; spoedig komt de mānoin. Hij komt, maar hij weet van den levende niet af, hij denkt, dat de doode er slechts is. Hij schuift de klapperbladeren van een, om in het graf te zien, hij fluit aan de voeten, maar de doode antwoordt niet, hij fluit aan het hoofd, de levende autwoordt bedriegelijk, hij beloog hem.

De jongere lag, gewapend met een hakmes. Als die mānoin fluit, vangt de jongere hem en slaat het hoofd van den mānoin af. De mānoin sterft, de jongere sterft ook; men begraaft allen tegelijk.

Aant. 1. Mānoin. Wat de Papoea's van den mānoin beweren, komt in veel dingen overeen met de verhalen omtrent den weerwolf elders. De mānoin is een mensch, die verschillende gestalten kan aannemen en in die gestalten zijne prooi nadert. Door hem te treffen, veroorzaakt hij den dood binnen eenige dagen. Narr het verhaal wil, komt de mānoin immer den eersten nacht, dat de prooi begraven is, op diens graf. 't Graf wordt bewaakt en men tracht dan den mānoin te vangen. Een slaaf of slavin, die ongelukkig in de buurt vall zoo'n graf wordt gezien, is onder beschuldiging een māuoin te zijn, tot den dood veroordeeld.

2. Rum Srām. Indien in eene familie meerdere jongelingen zijn, zoodat het huis te klein wordt, om hen te bergen, dan maken die jongelingen zich een klein huisje in de nabijheid der familiewoning. Dit huisje heet rum srām. Behalve deze huisjes, had men vroeger in de Dore-Baai de groote rum srām, die al meermalen in werken 
over N. G. beschreven werd en afgebeeld (Wilken. Iets over de beteekenis van de ithyphallische beelden bij de volken van den Indischen Archipel; Horst, De rum-srams van Nieuw-Guinea; J. L. van Hasselt, Gedenkboek van een 25 jarig Zendelingsleven [blz. 27] enz. enz.).

Wat de afl. van dit woord betreft, is meer dan eene gissing gewaagd. Bewezen is echter nog geene.

3. Aběruk. De rum srām is met de groote woning verbonden door een hoogst eenvoudige brug, meest alleen bestaande in een horizontaal liggende boomstam. Deze toegang heet abĕruk. De brug vau het strand naar de familiewoning heet adōrĕn. Ook boomstammen en brugjes over een rivier dragen den naam a b̌ruk.

4. In de Papoesche woningen onderhoudt men 's nachts verschillende kleine vuurtjes, waarbij men zich te slapen legt.

5. Samfar, armband uit een schelp vervaardigd; a mo, breede armband aau de pols, van bladeren gevlochten; $\mathrm{kak}$, smalle gevlochten armband aan den boveuarm; sarāk, zilvereu armband, van rijksdaalders of guldens gemaakt.

$$
\text { Uri } \left.{ }^{1}\right) \text {. }
$$

Ras ōso Uri, i wan bĕknìk bjedi Pasai, i serf rumun. Pasai kukĕr rumgun suru, si sām nāf $\left({ }^{2}\right)$. Ma fāsau si sma rumun. Uri i mām, for i das ro sup, i swarepĕn Uri sko, si sma rumun rape, si kun i. I mbrēin, ma i d'ek ro kris.

Pasai kukĕr rumgun suru, si bur wer ro wai. Si rama fauām kris, Uri i d'ek ani, Pasai i san sārfer bjeda fa i pōs in. I pōs in kukĕr rumun wesi. Uri i mām ōruĕ, i d'un bur rumun ( 3 ) ro kaju. Uri rwasi su kwaim kaku. Pasai i swarepĕn in, i d'an rumun, i sjob sarfer fasau, bape roba! I swarepĕn in, i d'an rumun ani, i fes wesi bĕsuru ro kaju. Uri i d'un bur i wer. Iriria rumun rwasi (4) kakō, ma rwuri ma kraf kaim.

Rumgun, su so Pasai, su msor, si sma in ba, ma rumun kakō ibro. Si borĕs kwaimba, Uri i d'or : "Pasaio !" Pasai i mnāf, ōso i d'or, d'ōbo: "Wō, mundiri i d'or aja? Ko serf i !" Bape krisraim, na dwārk Üri, si mām i ba. Si bur. Si borěs knìk wer, Uri d'or wer: "Pasaio!" Pasaisko, si serf i wer. Iriria bĕkiōr. Si serf i běkiōr, ansōna Uri kōfēin : "Aja, j’or au!" Ja mām, mgo sma rumun, ja mām for i das ro sup."

Rumgun su ro Pasai, su kōfēin : "Albōi ko sma kada, ko sma, bape Pasai, i pōs in kukĕr rumun, in d'an kam ibro, ma ko sma 
ōsoba kwar." Uri d'ōbo: "Mgo serf rumun rās bĕsiper ma mgo sma roioba, aja, ja serfba, ja sma ; w'akmām." Pasai i māmnepĕn rumun, Uri fasna, i kōfēin: "A, rumun jedi ìs ōrnĕ, rumun ro kaju."

Uri i wan Pasai sko kukĕr rumun be rum. Ma i, i san we ōser be rum, i kēin ro rum rape. Pasai sko s'ek rum, si kāndor, si kōeein : "Knîkirine ko bor bur Uri ro kris, ma ansōna i kein ro rum rape."

Rāso wer, Uri ma Pasai kukĕr rumgun subesi, s'as uk warběki. Knîko, su rama ro rowār wēsĕ, Pasai i mām be kruri, i mām ōso ro rumgunsi nēri i msar. Uri kōfēin : "Wa kuk i ro āmbober beda ma wa sjob i," S'ek ro sup, Pasai i mām rumgun ani i mar. Pasai i msor Uri, d'ōbo i srer i. Uri i kōfēin: "Ja kōfēin faro au, rumgun bedi i kin āmbober, ma wa sjob $i$, bape mangundau wa kuk $i$.

Rāso wer, i pum rōbčrōk bjeda. Pasai i fukĕn i: "Wa frư rōbĕrōk beda rariso ?" I köfein : "Rib ro snari jedi snēri, ja fes ro rōběrōk ōrně!" Pasai i kōfēin faro snari bjedi kakō: "Wa barēk, ja kēruk rib ro snembri !" Bape snari mēwēr, d’ōbo: "Nēri ja mar!" Pasai d'ōbo: "Roba, Uri i frur rōbĕrōk bjeda kakō ro rib snēri suari bjeda." Pasai i d'or māngěnēm, snari i kōfēin : "i bje!" Ma Pasai i kēruk, kēruk, ma snari i mar. Pasai i msor Uri, d'ōbo, i srer i. Bape Uri kōfēin, i kōfēin ōsoba ro rib ro snari snēri bjeda.

Rās ōso, Uri i wan rumgunsi, si kfo i. I rir rumgunsi ro mob suru ma i d'orĕs ro fandu. Si kfo i, i kāndejĕn bur iko na, ma rumgun si kfoiai mangunsi. Rumgun, si msor, bape i kōfēin : "Aja maroba, mangunmgo.

Rāso wer, i wan rumgun suru, su perĕm i kukĕr sumber. Sumber, su kam, su sar kaku. Ōso, nēri i prer i ro rwa sar, wēsĕ ro rwa kaku. Sumber, nēri su kiur i, i kāndejĕn wer ma rumgun su mun māngunsu. Kawāsa, si msor i, Uri d'ōbo: "Aja fauba, mangunsu su perĕmiai su."

Rāso wer, i wan rumgun kapirare, si rer wa mgun sena. Na bark kam, i pās kabu knām bĕba, ma i sāpi ro bo wai mgun nakaim, na mef kām. Si msor i, i d'awes rumgunsi, d'ōbo: "Mgo bārbor so, mgo fuāk fanām kabuknām, mgo māmba, i kar rape. 
Rās ōso, kawāsa s'afer rum. Kuîko s'afer pōsa kwar, ma robĕan i miais kwar, Uri i rama. I mam ōs, i kofēin: "Wō, mg'afĕr kukĕr ōs awer, wam i pōk knìk, i d'un ōs!" "K'afer rariso?", kawāsa si kōfēin. Uri d'ōbo: "Mgo rir a na fanām kaku, rēsěri mgo rir sāprōp ro bo". "Kaku ro Uri $\left({ }^{5}\right)$ !" kawāsa, si kōfēin. "Ko māın, mēkēm, mēkēm i kēin ro sāprōp". Si san ōs na wer, ma si rir a na kukĕr sāprōp. Bape wam i pōk kukĕr mēkēm — sāprōp bur kam, rum i kar ma kawâsa, si mar.

Ras ōso, Uri i mam rumgunsi, s'anan. I fukĕn faro si: "Mg'an rosei ?" S'ōbo: "Ko kaprersna!" Uri d'ōbo: "K'an kaprendi rariso?" Si kōfēin: "Ko sjob kukĕr kafrus $\left({ }^{6}\right)$ borik»". Ma Uri d'ōbo: "J'akan kaprendi kada!" Rumgun si sjob i, si sjob - isōf kaprendi sasiar, ma Uri i mar. Si bur ma si disĕn : "( $\left.{ }^{7}\right)$ Ko mun Urio - Uri man bĕrariso? So orōngo, sasorōngo, Pasai sorōngo, sasorōngo!"”

Si disĕn rariria, si mnāf ōso i fukĕn: "Mgo mun mundiri?" Rumgun, si kōfēin: "Ko mun Uri!" Uri d'obe: "Aja Uri!" Uri mangundi i fukĕn faro si kwar: "Mgo mun mundiri?" Si mām i, si kāndor, si bur, si frar.

Rāso wer, Uri i mbrein be swan, i mäm wongor. Wōngor d'ōbo: "Kawāsa, si sāndik au, s'ōbo au wa pānde $\left({ }^{8}\right)$ so, wa mambri kaku. Uri kōfēin : "Aja baboi!"

Wōngor i kōfēin wer: "Wa so jāfēn beda ro aja, bape wa fes rib rēsĕri ro krāf bjeda. Uri $i$ fes rib ro kraf bjeda, rēsěri i so jāfēn be wongor. Jāfēn i kiur wōngor, ma i d'as, i d'as be soren fandu. Uri i d'or: "Napirmō, wa fnāk awer, knìko ja ro." Wōngor kōfēin: "Roba, ras inè wa mar, wa sāndik au māngĕnēm". War i sia ro mgasi rape, ānsōna Uri i swarepēn ino bjeda, i sia ro mar bjeda, i kēruk rib ma i bur.

\section{Uri.}

Op een dag, droeg Uri aan zijnen jongeren broeder Pasai op, een varken te gaan zoeken, Pasai met zijne beide jongens gingen met een hond op varkensjacht. En spoedig vinden ze een varken. Uri ziet vuur rooken in . het bosch en denkt bij zich zelven: Uri en de zijuen hebben reeds een varken, ze roosteren het. Hij gaat heen en klimt in een kriesboom.

Pasai met zijne beide jongens vertrekken weer per prauw. Als ze bij den kriesboom, dien Uri beklommen heeft, gekomen ziju, 
werpt Pasai zijn vischlijn uit om te visschen. Hij vischt met een varkenspoot. Uri, die dit ziet, haalt het varkensvleesch van den angel weg. De arm van Uri is zeer lang. Pasai denkt, dat een visch het varkensvleesch weghaalt en hij haalt spoedig zijn vischlijn in, maar neen! Denkende, dat het varkensvleesch door een visch werd weggehaald, bindt hij den tweeden poot aan den angel. Uri haalt het weer weg. Aldus de voorpooten ook en den kop en het geheele lichaam.

De beide jongens, die met Pasai zijn medegegaan, zijn boos, omdat ze geen visch hebben, en het varken ook op is. Zij zijn nog niet ver weggeroeid, als Uri roept: Pasaio!" Pasai hoorende, dat iemand hem roept, zegt : "Wie roept mij? Laten we gaan zoeken!" Maar de kriesbladeren beletten hen, Uri te zien. Zij gaan heen. Als ze weer een eind geroeid hebben: roept Uri weer: "Pasaio!" Pasai en de zijnen zoeken hem weer. Zoo ging het drie malen. Als ze hem de derde maal zoeken, zegt Uri: "Ik, ik roep u!" Ik heb gezien, dat ge een varken hebt, ik zag vuur in het bosch.

De jongens van Pasai zeggen: "Ja, wat het hebbeu (krijgen) aangaat, we hebben, maar Pasai hij heeft met varkensvleesch gevischt, de visch heeft alles opgegeten en we hebben niets meer." Uri zegt: "Gij hebt den ganschen dag op varkens gejaagd en ge hebt niets, ik, ik heb niet gezocht en ik heb wel; zie!" Pasai beziet het varkensvleesch, dat Uri toont en hij zegt: $\mathrm{Ah}$, dat is mijn varkeu, 't varkensvleesch van den angel."

Uri zendt Pasai en de zijnen met het varken naar huis. En hij, hij werpt éen been naar huis en is reeds thuis. Als Pasai en de zijnen klimmen in zijn geklommen huis, zijn ze verbasd en zeggen: "Zoo juist verlieten wij Uri in den kriesboom en nu zit hij al thuis".

$\mathrm{Op}$ een anderen dag zwemmen Uri en Pasai met hunne jongens eene rivier over. Bijna zijn ze aan de andere zijde, als Pasai omziende één der jongens ziet verdrinken. Uri zegt: "Steek hem met je bamboe en trek hem!" Als ze op den oever ziju, ziet Pasai, dat die jongen dood is. Pasai is boos op Uri en zegt, dat deze hem belogen heeft. Uri zegt: "Ik heb je gezegd, dat je jongen de bamboe moest grijpen en gij hem trekken, maar gij zelf zelf hebt hem gestoken."

Op een anderen dag sloeg hij op zijn tifa. Pasai vraagt hem: "Hoe hebt ge uw tifa gemaakt?" Hij zegt: "Het vel van de buik 
mịner moeder heb ik gebondeu op deze tifa!" Pasai zegt tot zijue moeder ook: "Ga liggen, dan snijd ik de huid van uw buik!" Maar de moeder weigert, zeggende: "Ik zal sterven!" Pasai zegt: "Neeu, Uri heeft ook zijn tifa van de huid zijner moeder gemaakt." Pasai vraagt zoo dikwijls, dat de moeder zegt: "'t is goed!" En Pasai snijdt snijdt en de moeder sterft. Pasai is boos op Uri, hij zegt, dat deze hem belogen heeft. Maar Uri zegt, dat hij niet gesproken heeft van de buik zijner moeder.

Op een anderen dag beveelt Uri de jongens hem met pijlen te beschieten. Hij zet de jongens op twee rijen en hij stat in het midden. Als ze de pijlen afschieten, ontwijkt hị de pijlen en de jongens beschieten elkander. De jongens zijn boos, maar hij zegt: "Ik heb het niet gedaan, gij hebt het zelf gedaan!"

Op een anderen dag beveelt hij twee jongens, hem met een hakmes te slaan. Beide hakmessen waren zeer scherp. Een zal hem links slasn, de andere rechts. Als de hakmessen op hem zullen neervallen, ontwijkt hij weer en de jongens dooden zich zelven. De menschen zijn boos op hem, maar Uri zegt: "Ik niet, zelve hebben ze elkander gehakt"”.

Op een anderen dag laat hij kleine jongens, hunne kleine prauwen op eene rij leggen. Als ze alle op eene rij liggen, trekt hij een groote ijzerhoutboom uit en die valt op alle kleine prauwen, zoodat zij alle bersten. Zij zijn boos op hem, maar hij doet hun verwijtingen, zeggende: "Gij zijt zeer ondeugend om te spelen bij een ijzerhoutboom, hebt ge niet gezien, dat hij reeds gebroken was?"

Op een auderen dag was men ergens bezig met dak dekken. Als ze bijna gereed zijn en 't eten al gaar is, komt Uri. Als hij de atap ziet, zegt hij: "Wat, dekt niet met atap, want als de wind zich éen weinig verheft, neemt hij de atap mee!" "Hoe moeten we dan dekken?" zegt het volk. Uri zegt: "Leg de houten zeer dicht bij elkauder en dan legt ge er aarde boven op". "Uri heeft gelijk!" zegt het volk. "We zien als het regent, dat de regen op de aarde blijft staan". Ze werpen de atapen weer weg en ze leggen de houten met aarde. Maar als de wind zich een weinig verheft en de regen valt, dan spoelt alle aarde weg en het huis breekt en het volk sterft. 
Op een dag ziet Uri jougens aan 't eten. Hij vraagt aau heu: "Wat eet gij?" Ze zeggen: "Ouze tongen!" Uri zegt: "Hoe eten we de tong?" Ze zeggen: "We trekken die uit met een kafroes doorn". En Uri zegt: "Ik wil ook wel mijne tong eten!" De jongens trekken, tot de tong er uit komt en Uri sterft. Ze gaan weg en ze zingen: "Ko mun Urio - Uri man berarisu? So orōngo, sasorōngo, Pasai sorōngo, sasorōngo!"

Als ze zoo zingen, hooren ze iemand vragen: "Wien hebt ge gedood?" De jongens zeggen: "We hebben Uri gedood!" Uri zegt: "Ik ben Uri!" Uri zelf had aan hen gevraagd: "Wien hebt ge gedood?" Als ze hem zien, zijn ze verbaasd, ze gaan vluchtende heen.

Op een anderen dag loopt Uri aan het strand en ziet hij een krokodil. De krokodil zegt: "De menschen prijzen u, ze zeggen ge zijt zoo knap, ge zijt een rechte held". Uri zegt: "Ik wel zeker!"

De krokodil zegt weer: "Werp uw harpoen op mij, maar bind den riem eerst aan uw lichaam". Uri bindt den riem aan zijn lichaam en toen werpt hij den harpoen op den krokodil. De harpoen treft den krokodil en hij zwemt, hij zwemt naar het midden van de zee. Uri roept: "Neef, speel niet, zoo dadelijk ben ik verloren". De krokodil zegt: "Neen, vandaag sterft ge, ge prijst u te veel". Als het water hem reeds tot de oogen komt, denkt Uri aan zijn mes, dat in ziju schaamgordel is, en hij snijdt den riem door en hij gaat heen.

A a nt. 1. Uri. Deze Uri is eene eenigszins mythische persoonlijkheid. De verhalen omtrent hem ziju half kakōfein (fabel) en half kakajik (legende). Hij wordt beschreven als een ontzaglijke reus. Maar vooral is hij populair wegens zijne leugens. In dezen vertoont hij wel de type van den Papoea.

Van hem hoorde ik ook vertellen, dat toen Manguudi, de schepper der Papoea's hen verliet, omdat ze hem niet meer vertrouwden, deze in zijn plaats Uri aanstelde. Aan Uri ontbrak de woudermacht van Mangundi. Om toch invloed zich te verzekeren onder de Papoea's leerde hij hun de feesten en gaf hun sieraden.

Behalve door zijue leugens, is hij ook bekend door zijne hartstocht voor vrouwen. Aan zijue beschrijving ontbreekt dan ook niet een abnormaal groote penis. Overal, waar hij kwam, vroeg hij zich eeue der dochteren des lands tot vrouw. Gaf men hem er eene, dan schoot hij met een pijltje, gemaakt van den nerf der sago-palmbladen. 
Dit pijltje nog groen en frisch ontwikkelde zich tot een sagobosch. Gaf men hem geene vrouw, dan schoot hij ook met zulk een pijl, doch dat was dor en, geen sagobosch ontstond.

2. $S \bar{a} m n \bar{a}$. In den regen met een hond varkens opsporen.

3. Rumun. Varken, maar ook varkensvleesch, gedeelten van het varken.

4. Rwasi. Arm. hand. Van dieren voor poot.

5. Kaku ro Uri! Uri heeft gelijk, lett.: 't Gelijk aan Uri!

6. Kafrus. Liaan met scherpe doornen.

7. Het lied door de jongens gezongen kan ik niet vertalen. 't Begin is: "We dooden Uri" Wat een man is Uri? 't verdere is geen gewoon Noefoorsch, zoover ik kan nagaan.

8. Pānde. Knap. Als kuap geldt bij den Papoea ieder, die listig is en vernuftig is in het liegen.

Behalve de kakofein, die in de voorgaande bladz. verhaald werden, bestaat onder de Nufooren een vorm van kakōein, waarvoor ik geen beter woord vooralsnog weet dan recitatief. Ze worden in eenen zekeren dreun opgezegd, niet gezongen, gereciteerd. Worden de gewone kakofein alleen na zonsondergang verhaald, dit soort kan men ten allen tijde hooren.

Uit taalkundig oogpunt zijn ze van belang, omdat er oude taalvormen in bewaard bleven, die in de gewone spreektaal verloren gingen.

'k Vond de volgende vormen van dergelijk recitatief en ik geef ze letterlijk weer, daar ze juist uit taalk. oogpunt van belang zijn.

\section{Recitatief.}

1. Apuje, apuje, wa kunō(') ufēnka. Kero ma $\left(^{2}\right)$ ! J'an ōso, w'an ōso.

$\mathrm{Ku}$ randa, k'orĕs, ku fakakir. Neibō rōmsike $\left({ }^{3}\right)$, samibō $\left({ }^{4}\right)$ rōmsike, ku mām we $\left({ }^{5}\right)$ dama $\left({ }^{6}\right)$; saroì $\left({ }^{7}\right)$; wa bĕjun pōkēmo, darjando $\left({ }^{8}\right)$ winusi $\left({ }^{9}\right)$ sawārwa $\left({ }^{11}\right)$ ma.

$\mathrm{Ku}$ j'un sumbero (11) ra, ku san ro wai āmbero $\left({ }^{12}\right)$ dōri. Asisō $\left({ }^{13}\right)$ kero $\left({ }^{14}\right)$ asiswa bĕrano $\left({ }^{15}\right)$ kero.

1. Grootmoeder, grootmoeder, kook ufen. Een weinig aan mij. Ik eet één, gij eet één.

Wij beiden gaan strandwaarts, wij staan, wij staan op onze teenen. Meisjes, jongens, wij zien naar daar; walvisch, prauw brengt gierst, vaart de baai om de kaap in. 
We halen hakmessen, wij werpen in de prauw, die naar het vreemde land vaart. De vlag (kam) staat, de vlag (kam) wappert staande.

1. Ufēn. Aardvrucht. (Colocasia antiquorum).

2. Ker. Weinig. Ma duidt aan de richting naar den spreker. Kero ma, - dus een weinig aan mij.

3. Rōm is het stamwoord yoor rōmgun (rom mgun) en rō$\mathrm{mawa}(\mathrm{r} \overline{\mathrm{m}} \mathrm{mawa})$. Beide woorden beteekenen jongen, zoon, volgeling. Mgu $\mathrm{n}$ is in het Nuf. klein, jong; maw a ging op zich zelf staande in het Nuf. verloren, op Meos War en Ron bleef het woord bestaan als klein en het vormde in beide dialecten mawauri (jongere broeder), dat in het Nuf. is : bĕknìk.

Op Gebi bestaat een woord a wai voor kind.

Het stamw. $r \overline{o m}$ in beide woorden is op zich zelf staande ook verloren gegaan. Hier staat het echter op zich zelf, voorafgegaan door neibo en samibo. $\mathrm{Nei}$ is meisje. Samibo is ook verloren gegaan, doch moet dan het adj. voor jongen zijn volgens mijn zegsman.

5. We (be), na a r.

6. Da ma. Da a r. Dit woord ging ook verloren. Daar is in het huidige Nuf. orwa.

7. Saroî. Walvisch. Wordt hier als beeld genomen, omdat het een groote prauw is, die nadert.

8. Darjan (misschien arjan), om een kaap heen varen.

9. Winusi. Eeue baai of reede met zeer breed strand.

10. Sawōrwa. Ka a p. In het huidige Nuf. is kaap swapōr of $s \bar{a} w$ a por.

11. We halen hakmessen en werpen die in de prauw. Dit doelt op eene gewoonte, die onder de Nufooren bestaat om een prauw, die voor de eerste maal geroeid wordt te beschenken. Hakmessen, borden enz. worden in de prauw of in het water geworpen. De roeiers dniken naar de voorwerpen, waarmede hunne prauw beschonken wordt.

12. Wa āmbero. $\bar{A} m$ ber, vreemdeling. W a $\bar{a} m$ ber, prauw van vreemdelingen, ook prauw, die naar het land der vreemdelingen vaart. De $\bar{a} \mathrm{~m}$ be r begint met Salawati.

13. Asis. Kam. Men denke hier aan de Nufoorsche kammen, bestaande uit een reep bamboe, waarin tanden door gedeeltelijke splijting zijn gemaakt. De kam dient o. a. als sieraad. Men zet die 
dan in het haar en versiert hem met stukjes goed of met kraleu. Dergelijke kam is als beeld genomen voor de vlag, die op de prauw wappert.

14. Kēro. Is ook een verloren gegaan woord, dat staan moet beteekenen. $\mathrm{Nu}$ is staan : orēs.

15. Berano. Wapperen. Tegenwoordig kabiraru.

Variant op 't voorgaande is :

la. Romgun samiauja (1), ku randa, ku fakakindo, ineibo rōmsi ke, samibo rōmsi ke, ku mām we dama saroi wa bĕjuu pōkēmo dariariso winusi sawarwa ma.

Asiso kero, asiswa berauo kero.

$\mathrm{Ku}$ j'un sumbero, ku san do wai ambero dōri, asiso kero, $\left({ }^{2}\right)$ asiswa mberauo kero.

1. De grootmoeder, die in $\mathrm{N}^{0} \mathrm{l}$ werd angesproken, is hier vervangen door "romgun samiauja". Romgun, kind, sami, biijk'baar vroeger onderscheiảing van het mann. geslacht.

2. Boven zagen we reeds, dat kēru voor staan niet meer gebezigd wordt en vervangen is door orēs. Opmerkelijk is dat het gelijkluidend kēru, steen, in het Roonsch $\bar{o} \mathrm{r}$ is. Dat de k. wel afvalt aan 't begin van een woord vinden we ook in rib (huid, riem), dat in het Roonsch luidt $\mathrm{krib}$. En dat de e met o afwisselt in mēuu (dorp) en $\mathrm{m} \bar{o} \mathrm{nu}$ in het $\mathrm{R}$.

Als vervolg van 1 werd mij eens meegedeeld het volgende:

Isei ( $\left.{ }^{1}\right)$ kor bjesi běbarĕk na pōnja ?

Ma isei wa pē $\left({ }^{2}\right)$ apuj kor bjesi so bĕbarĕk na ponja ma.

d. i. Wat voor beenderen liggen er voorin?

't Is niets, de beeuderen van grootmoeder liggen voorin.

1. Is ei. W at voor. Wordt als zoodanig ook niet meer gebezigd.

Ik neem hier over wat Prof. Kern onder sebe opmerkt in zijn Verhouding van het Mafoorsch tot de Mal. Pol. talen.

"S ébe, wie ? De eerste lettergreep bevat vermoedelijk het persoonaanduidende si, dat we in 't Kawi sy - a pa, wie, in 't Jav. verbasterd tot sapa, Mal. siy-apa, Tag. si-anu enz. aantreffen. De Ambonsche tongvallen en 't Bulusch hebben sei."

Men hoort nu in plaats van isei, rōsei. Rō of roi is ding. 
2. Wapè of wa pe kan ik niet verklaren. Miju zegsman beweerde, 't beteekende zooveel als: "'t is niets."

2. - Apusē, ja mām i.

- Insōpē? ( ${ }^{1}$ )

- Fungēm i so i rajama.

- Fungēmbĕrori? ${ }^{(2)}$

- Fungēm, ja mun ra bĕmar ani.

2. - Grootmoeder, ik zie hem.

- Wie is dat?

- Fungemi, hij komt met hem.

- Welke Fungēm?

- Fungēm, ik doodde; de bewuste, die dood is.

1. Insōpē? Wie is dat? Wordt in het Nuf. niet meer gebruikt.

2. Bĕrori? Welke? Wordt achter persoonsuamen gebruikt om te vragen wie.

Wellicht is dit ror terug te viuden in riori, dat men dikwijls hoort, b.v. "Ik heb tabak van mijuheer gekregen!" Ja sma sāmbako ro tuwan riori. Dit riori zou dan zijn van hem of van dien.

3. Sāmfarwe baje, swaswaf rum inẻ raweri, wa rowi, wa kōfēin badadir awer. Manisu bĕrowi wa kondo rum inè rawendi, j'afnana kewederewa. Winsi sĕpēre-pērena ma-w'anba, j'anba, āräre bĕkōkēr, ārāre běkōkēr.

3. Groote $s \bar{a} \mathrm{mfar}$, die hangt in de voorgalerij van dit huis, gij vliegt, zeg niets. Manisu, gij vliegt, gij zijt in de voorgalerij van dit huis, j'afnana kewederewa. De vrouwen maken eten gereed - 't is gereed, gij eet niet, ik eet niet, haal het eten weg, haal het eten weg.

3. Bevat eene toespraak tot een $s \bar{a} m f a r$ (armband uit schelp gesneden). De woorden, die ik onvertaald liet, ken ik niet.

't Doelt op de Nuf. gewoonte, om den $3^{\text {ev }}$ nacht na het vertrek van eene prauw naar Salawati of verder gelegen oorden, te waken, waarbij men weinig of niet eet. 
Ook van $\mathrm{N}^{\circ} 3$ bestaat een variant, meldende dat de prauw $\mathrm{m}$ is kabori (zeer dikke schildpad) meenam.

Wat sommige, niet meer gangbare woorden aangaat, per $\bar{e}$ is gereed maken van eten, pērèna, 't is gereed.

A rarē bēkōkēr zou zijn: haal het eten weg.

4. Mānsaro apusē, wa kwōk ma k'ano kamisānsia.

Rōnesē ria kara si ro mēsrāndia, serakanira, si rama nira, wjeso, wa bje so rawānja; mānsaro Kaibùsi wje so wa bje so rawāueja.

4. "Oude man, grootvader, word wakker en eet voedsel"! !

"Er is niets, als er er wat was, zou ik eten. 't Is al avond. Ik heb slaap, ik eet niet. Als je goed waart voor den ouden Kaibusi, zoudt ge hem eten gegeven hebben, toen 't nog licht was".

Dit is de vrije vertaling van 't recitatief, dat heel wat woorden bevat, die men nu niet meer hoort.

$\mathrm{K} w \overline{\mathrm{o}} \mathrm{k}$ is wakker worden.

$\mathrm{K}$ a misania, voedsel. Dit woord bevat an, dat eten is.

$R \bar{o} n e s \bar{e}$ is blijkbaar rō, ding en het boven reeds behandeld vragend isei of sei, wat, wat voor.

Mèsrāudia, avond. Mēsēr is de volgende dag, rāndia warschijnlijk begin, dat we nu nog hebben als rāndāk. Māsrāndia zou dan zijn, de volgende dag begint. De Nufoor begint den volgenden dag met den avond.

Serakanira, si rama nira werd mij uitgelegd als: Ik heb slaap, ik eet niet. Maar ik kan er niets in vinden, dat op Nuf. lijkt. 't Zou in het Nuf. luiden : "Eněf i min aja, j'an ba.

Wjeso, wa bje so rawānja enz. zou moeten beteekenen: Als ge goed waart, zoudt ge deu ouden Kaibusi te eten hebben gegeven toen het licht was! Maar ook uit dit gezegde kan ik niet veel Nuf. opdiepen. Alleen bje, goed, wa, gij en so, zoo. Wje so zou de samentrekking kunnen zijn van wa bje so en 't zou ook kunnen zijn, dat hier ook de $b$ in $w$ overgaat.

5. Nei aujai rwa ma, ku sjobo kawra pāpero ma, ku wuk i prankaguno ino koro, w'an i kōndi ke; mano, w'an i kondi ke.

5. Meisje, kom, wij beiden trekken een rood touw herwaarts, wij pakken er visch in, gij eet tot de graat, vogel, gij eet tot het been. 
Nei is het gewone Nuf. meisje. Aujai vonden we onder 1. reeds in romgen sami a uje. 't Is wellicht het pers. vnw. v. d. $2^{\mathrm{e}}$ pers. a u, (gij); $\mathrm{Rwa} \mathrm{ma} ; \mathrm{Ma}$ is herwarts, $\mathrm{rwa}$ het w.w. $\mathrm{ra}$, gaan met het ingevoegd pers. vnw. v. d. $2^{\mathrm{e}}$ pers., Kawra; het tegenw. Nuf. woord voor touw is a bra, al meermalen merkten we op, dat afslijting van de $\mathrm{k}$ niet zeldzaam is en de verandering van $b$ in $w$ zeer gewoon is; Papero, dat rood moet ziju, ken ik niet, het gewone Nuf. woord is rik( $\left.{ }^{1}\right)$. Wuk, wellicht buk, dat meermalen gevoegd wordt bij een znw. om er een w.w. van te maken, b.v. sansum, kleed, buk sānsum of bĕ sansum, kleeden, bekleeden, een kleed doen dragen; Prankaguno, pak, het Nuf. woord voor pak is pangum. Ino is hier visch, het gewone in met het in deuntjes en zangen zoo gewoue achtervoegsel o. Wat k oro hier beduidt, weet ik niet. Kōndi is kor (graat), de r genasaleerd tot ndi. Mano, vogel. Kondi is behalve graat ook been.

6. Inēija, samia aujajes, mukansa werbai. Snami, kmami su j'uno kapumom benara, su sano bonjaswa. Su ramu fema mausjori sjoriwe bawi k'au apapu ba puwa pawa pumarengka.

6. Van dit deuntje is me niet veel duidelijk. Een meisje (in eija) en een knaap ( $\mathrm{samija}$ ) worden vermaand niet te huilen. Huilen is in het tegenwoordig Nuf. kanēs; mu kansa werbai is dan: gij beiden huilt niet weer. Verder: uw moeder eu vader hebben st... weggebracht, (Suami, kmami su j'uno kapumom). Wat benara is weet is niet. Vervolgens: su sano bōnjaswa, ze hebben 't bij gindschen berg weggeworpen.

R a m u moet zijn verdwalen. In het tegenw. Nuf. is ramuma verdwalen, afzwerven.

Fe m a moet zijn afdalen. Nuf. sabu.

Mansjori werd mij vertaald als bōsĕn, koraalrotsen.

Bawi zou zijn kaap.

A papu. Een schelpsoort.

Wat puwa pawa pumarengka beteekent weet ik niet. De beteekenis van 't laatste gedeelte is dan:

Bij 't afdalen (van den berg) naar de koraalriffen (waar men schelpdieren zoekt) zijn vader en moeder verdwaald, wat tengevolge had, dat de thuisblijvende geen a papu te eten kregen.

(1) Zie Spraakk. der Nuf. taal, blz. 12.

7• Volgr. VII. 
7. Wō rumbo, rumbo, sjēnsjē sawa.

Deze woorden, beweert men, worden uitgesproken, als er aardbeving is. Ze zouden beteekenen:

't Huis beweegt - (w⿳亠 r u mba, rumbo).

't Is uit - (sjēnsjē)

(de aardbeving) is verder gegaan - ( $\mathbf{S}$ a wa).

8. Insiri fjais sasaro insa wendi, rumboi sjēnsjēn sewa.

Deze woorden vormen een deuntje, gebruikelijk bij 't zelfde spelletje, waarbij hollandsche kinderen hun "Torentje, torentje bossekruid" euz. teu gehoore te brengen.

De vertaling der verschillende woorden is, naar men mij inlichtte: Insiri fjais - van onderen naar boven.

sasaro - nog een er boven.

insa wendi - weer één.

rumboi — de top.

sjēnsjēn sewa - is bereikt.

Wat insa wendi betreft, insa is opdat en wendi (wer) is weder, nog een; rumboi is rumbo, op het huis.

9. Apaj, buko majo rōröfē e sapi ro borsma inderi bo orwa fē irōre sasar ārōre sasar knìkē kini auwe kjokjo kjo.

Het spelletje in 8 is z.a. bij ons met de duimen, doch er bestaat nog een dergelijk spelletje, waarbij men het vel van de hand eens medespelers tusschen duim en vinger neemt. Bij dit spelletje is het deuntje van 9 gebruikelijk.

Wat de vert. is, weet ik niet.

10. Tjun, tjunbe jauri tērērēre.

Deuntje van kinderen, die elkander bij de hand vasthouden en de handen ronddraaien.

11. Ëdjadi kor kor ěwara mānswēk, ě djadi kor kor ěwara manswēk.

Deun bij 't optrekken van een prauw, balken enz. 